\title{
PRELIMINARY ASSESSMENT OF THE LITHOLOGIC AND HYDRAULIC PROPERTIES OF THE GLACIAL DRIFT AND SHALLOW BEDROCK IN THE MIRROR LAKE AREA, GRAFTON COUNTY, NEW HAMPSHIRE
}

By Philip T. Harte

U.S. GEOLOGICAL SURVEY

Open-File Report 95-654A

Prepared in cooperation with the

U.S. Geological Survey Toxics Waste Group

Pembroke, New Hampshire

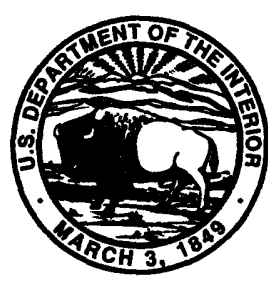

1997 


\title{
U.S. DEPARTMENT OF THE INTERIOR BRUCE BABBITT, Secretary
}

\author{
U.S. GEOLOGICAL SURVEY \\ Gordon P. Eaton, Director
}

For additional information write to:

Chief, NH-VT District

U.S. Geological Survey

361 Commerce Way

Pembroke, NH 03275
Copies of this report can

be purchased from:

U.S. Geological Survey

Branch of Information Services

Box 25425

Denver, CO 80225 


\section{CONTENTS}

Abstract

Introduction

Purpose and scope

Previous investigations

Hydrogeologic setting

Well-numbering system

Acknowledgments

Lithologic properties

Methods

Results.

Glacial drift

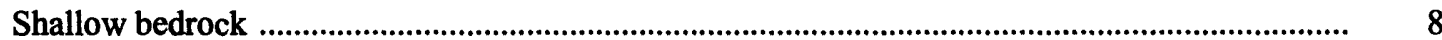

Hydraulic properties

Methods

Results.

Glacial drift

Shallow bedrock

Summary and conclusions

References cited.

Appendixes

A. Selected test hole and well data from the Mirror Lake area, Grafton County,

New Hampshire.

B. Lithologic logs, fracture locations, natural gamma logs, and screened intervals

C. Graphs showing water level responses from slug tests and best-fit lines for tested wells.

D. Information on parameters used for slug tests, Mirror Lake area, Grafton County, New Hampshire.

E. Graphs showing aquifer test water-level drawdowns and Neuman-type curves from aquifer tests

F. Information on parameters used for analysis of aquifer test from well clusters FS3C and CO, Mirror Lake area, Grafton County, New Hampshire

\section{FIGURES}

1. Map showing New England physiographic provinces and location of Mirror Lake area, Grafton County, New Hampshire

2. Map showing location of $(A)$ individual wells and borings and $(B)$ well clusters in the Mirror Lake area, Grafton County, New Hampshire

3. Graph showing grain-size analysis from representative glacial-drift samples in Mirror Lake, New Hampshire.

4. Graph showing relation between shallow bedrock fractures and altitude of land surface of test holes in Mirror Lake, New Hampshire.

5. Diagram showing shallow bedrock-well construction

6. Graph showing comparison of hydraulic conductivity values estimated from aquifer test, slug test, permeameter and grain-size analysis for wells CO1-18 and

WT-27 in the Mirror Lake area, New Hampshire.

7. Histogram showing estimates of hydraulic conductivity from glacial-drift hydrogeologic units in the Mirror Lake area, New Hampshire

8-9. Graphs showing water-level drawdowns from aquifer tests for:

8. FS3C cluster wells, Mirror Lake, New Hampshire 
9. CO cluster wells, Mirror Lake, New Hampshire.

10. Diagram showing textural classification relating grain size and specific yield.

11. Graph showing estimates of hydraulic conductivity from shallow bedrock in the Mirror Lake area by use of the Navier-Stokes equation and slug tests

\section{Tables}

1. Summary of fracture frequencies from shallow to deep bedrock intervals, Mirror Lake area, Grafton County, New Hampshire

2. Summary of hydraulic conductivity estimated from multiple techniques, Mirror Lake area, Grafton County, New Hampshire .....

3. Summary of porosity, specific yield, and estimates of storage coefficients, Mirror Lake area, Grafton County, New Hampshire 


\section{CONVERSION FACTORS AND VERTICAL DATUM}

\begin{tabular}{rcl} 
Multiply & By & To Obtain \\
\hline millimeter $(\mathrm{mm})$ & Length & inch \\
centimeter $(\mathrm{cm})$ & 0.0394 & inch \\
meter $(\mathrm{m})$ & 0.3937 & foot \\
kilometer $(\mathrm{km})$ & 0.6215 & mile \\
& Area & \\
square kilometer $\left(\mathrm{km}^{2}\right)$ & 0.3861 & square mile \\
& Volume & \\
cubic meter $\left(\mathrm{m}^{3}\right)$ & 35.3107 & cubic foot \\
liter $(\mathrm{L})$ & 0.2642 & gallon \\
& & \\
& Flow & \\
& 0.2642 & gallon per minute \\
& & \\
liter per minute $(\mathrm{L} / \mathrm{min})$ & Hydraulic Conductivity & \\
& 0.0000379 & foot per day
\end{tabular}

Sea level: In this report, "sea level" refers to the National Geodetic Vertical Datum of 1929--a geodetic datum derived from a general adjustment of the first-order level nets of both the United States and Canada, formerly called Sea Level Datum of 1929. 


\title{
PRELIMINARY ASSESSMENT OF THE LITHOLOGIC AND HYDRAULIC PROPERTIES OF THE GLACIAL DRIFT AND SHALLOW BEDROCK IN THE MIRROR LAKE AREA, GRAFTON COUNTY, NEW HAMPSHIRE
}

\author{
By Philip T. Harte
}

\section{ABSTRACT}

As part of the research by the U.S. Geological Survey to study ground-water flow and transport in low permeability fractured crystalline rock, field data were collected on lithologic and hydraulic properties of the glacial drift and shallow bedrock in the Mirror Lake area of Grafton County, New Hampshire. These data were used by other studies of the site to help develop conceptual models of ground-water flow and bedrock recharge from the glacial drift.

Test drilling at nine sites in ground-waterrecharge areas penetrated four types of glacial drift. They are, in descending order of horizontal hydraulic conductivity: stratified-drift deposits in kame terraces, ablation till, and a brown (weathered) and gray (slightly weathered) lodgment till with similar horizontal hydraulic conductivities. The lodgment tills contain 10 to 15 percent more silt than the ablation till, but $x$-ray diffraction results show that the mineralogic composition of the lodgment and ablation tills are similar. Permeameter tests on six cores from lodgment and ablation tills showed no difference in the ratio of horizontal to vertical hydraulic conductivities. Hydraulic conductivities of the glacial tills range from $1.0^{-6}$ to $1.0^{-10}$ meters per second. Specific retention of water is high in the till as indicated from estimates of porosity and specific yield. Porosities of the till approach 30 percent, whereas specific yield is less than 10 percent. Similarity between estimates of hydraulic conductivity from methods that integrate different sample volumes (permeameter, slug, and aquifer tests) indicates that the heterogeneity of the till is similar at all scales. This pattern implies that fractures in till either were not detected or are uniformly distributed at all scales of testing.

Test drilling of the uppermost five meters of bedrock at six test holes encountered schist and granite. The most highly fractured shallow bedrock was found at the highest elevation drilled. Estimates of hydraulic conductivity from slug tests showed that the most fractured site had a lower hydraulic conductivity $\left(4.0^{-9}\right.$ meters per second) than the hydraulic conductivity of the least fractured site $\left(8.5^{-7}\right.$ meters per second). Examination of all cores shows that the most fractured site has fractures that are filled with particles, which may account for the lower than expected hydraulic conductivity.

Results of two aquifer tests indicate a relatively good hydraulic connection between the glacial drift and shallow bedrock. No significant 
differences in horizontal hydraulic conductivity between the glacial drift and shallow bedrock were found

\section{INTRODUCTION}

Many waste repositories overlie till and crystalline rock in New England because of the widespread geographic coverage of these units. These waste repositories pose a potential risk to public health because contaminants that migrate downward into bedrock can flow with ground water over large distances and wells drilled in fractured crystalline rock provide public, commercial, and domestic water supplies. The potential for transport of contaminants in till and crystalline rock is controlled by the vertical and horizontal permeabilities of the formations. Therefore, information on vertical and horizontal permeabilities of till and crystalline rock is needed to make informed water-management decisions.

The Mirror Lake area of Grafton County, New Hampshire is the site of a multidiscipline research study by the U.S. Geological Survey (USGS) Toxic Waste Thrust Program to characterize fluid flow and chemical transport in fractured rock (Shapiro and Hsieh, 1991). The Mirror Lake area lies partly in the Hubbard Brook Experimental Forest, which is an ecosystem research site operated by the U.S. Forest Service.

As part of the USGS study, bedrock recharge processes including spatial patterns of recharge and rates of vertical flow from the glacial drift to bedrock are being characterized. Understanding bedrock recharge is important to help identify local and regional transport potentials of near-surface contaminants. A numerical ground-water-flow modeling exercise was performed as part of this effort to identify important bedrock-recharge processes (Harte, 1992; Harte and Winter, 1996; Harte and Winter, 1995). The information contained in this report was used to help develop conceptual models of flow to guide numerical experiments at Mirror Lake.

\section{Purpose and Scope}

This report presents findings from test drilling and hydraulic testing that were used to characterize the hydrogeologic properties of glacial drift ${ }^{1}$ and shallow bedrock $^{2}$ in the Mirror Lake area, Grafton County, New
Hampshire. The data-collection program was designed to collect information on factors that affect bedrock recharge. These factors include the existence of secondary permeability in the glacial till and fracture characteristics of the shallow bedrock.

Specifically, this report includes results from test drilling at nine sites throughout the Mirror Lake area, collection of borehole natural-gamma logs at these sites, $x$-ray diffraction of mineralogic composition of five samples, permeameter analysis of six lithologic samples, grain-size analysis of 20 lithologic samples, slug tests at nine wells, and short-term aquifer tests at two well clusters (FS3C and CO). Additional information is included from published reports to help characterize the lithologic and hydraulic properties of the glacial drift and shallow bedrock.

\section{Previous Investigations}

Few data on hydraulic properties of the glacial till and shallow crystalline rock of the New England region and their effect on bedrock recharge are available. Until recently (1995), information on hydraulic properties of glacial till has been restricted to studies in the Great Plains of North America (Strobel, 1993; Keeler and others, 1988; Keeler and others, 1989; Rowe and Booker, 1990). Information on hydraulic properties of crystalline rock has been derived principally from water-supply studies wherein large sections of rock are tested. Bedrock water-supply wells are constructed so that the uppermost $5 \mathrm{~m}$ of bedrock are sealed off with casing. The seal prohibits discrete hydraulic testing of the shallow bedrock.

The hydraulic properties of glacial till can significantly affect bedrock recharge because bedrock exposures are few and till covers most of the upland regions of New England (Harte, 1992). The hydraulic properties of till are partly controlled by the parent rock from which the till is derived. For example, Melvin and others (1992) reported that tills derived from crystalline rock typically have a greater sand fraction than tills derived from sedimentary rocks such as shale. The amount of sand in till and degree of sorting will affect its hydraulic properties. In general, the greater the sand

\footnotetext{
${ }^{1}$ In this report, glacial drift refers to all glacial deposits whether sorted (stratified drift) or unsorted (glacial till).

${ }^{2}$ In this report, shallow bedrock refers to top 5 meters of bedrock from the bedrock surface.
} 
fraction and the lesser amounts of silt and clay, the more permeable the till deposit. In southern New England, the median horizontal hydraulic conductivity of till derived from crystalline rock is about 3-orders of magnitude $\left(10^{-5} \mathrm{~m} / \mathrm{s}\right)$ greater than the median horizontal hydraulic conductivity of till from sedimentary rock $\left(10^{-8} \mathrm{~m} / \mathrm{s}\right)$ (Robert L. Melvin, U.S. Geological Survey, written commun., 1992).

Flow and chemical transport in till may be affected by secondary permeability caused by fractures.

Fractures in till can form from dissolution of carbonate minerals and by the reduction in volume of till caused by shrinking of minerals during the oxidation process (Strobel, 1993). Fractures also can form from bioturbation of plant and tree roots within $3 \mathrm{~m}$ of the land surface (Wayne Martin, U.S. Forest Service, oral commun., 1994). Fractures in tills have been discovered in the Midwest and Great Plains of North America and are shown to affect transport (Rowe and Booker, 1990). Fractures are typically found in weathered sections of till and absent in unoxidized tills (Keeler and others, 1988; Keeler and others, 1989). The bulk hydraulic conductivity of tills in the Great Plains are about 5.0-9 to $5.0^{-11} \mathrm{~m} / \mathrm{s}$ (Keller and others, 1988). The presence of fractures in tills of New England has not been studied.

The hydraulic properties of crystalline rock are controlled by the distribution and size of fractures. In crystalline rocks, the main flowpaths are joints, fracture zones, and shear zones (Gale, 1982a) and most values of hydraulic conductivity are controlled by the ubiquitous jointing of bedrock (Frank Trainer., 1988) rather than nonuniformly distributed features like zones of fracture and shear. Three mechanisms that form joints are sheeting, tectonism, and cooling of rock body after intrusion. Sheeting joints are parallel to the land surface and are caused from the release of pressure when overlying rock are eroded or when glaciers recede.

Previous investigations have described the general fracture characteristics of crystalline rocks of New England (Randall and others, 1988). In general, the vertical and areal distribution of fractures are a function of lithology, as well as stresses on the rock body. Fractures tend to be more extensive and permeable in homogenous, aluminum-deficit rocks (non micaceous) than in micaceous rocks with well developed mineral fabric. Micaceous rocks are less brittle and their weathering products have a high clay content.
Several studies have investigated the relation of fracture frequency and water yield with depth (Davis and Turk, 1964; and Knopman and Hollyday, 1993). However, data are not available on the shallow bedrock within $5 \mathrm{~m}$ of the bedrock surface.

\section{Hydrogeologic Setting}

Mirror Lake, with a drainage area of about $0.8 \mathrm{~km}^{2}$, is near the mouth of Hubbard Brook in the White Mountains of north-central New Hampshire (Winter, 1984). The area is in the central highlands province of New England (fig. 1; Denny, 1982). The geomorphology of the central highlands is controlled by the distribution of rock types, geologic structures, and intensity of metamorphism. Mountains and hillsides are composed of high-grade metamorphic rocks and granitic plutons, whereas valleys are composed of lowgrade metamorphic rocks (Denny, 1982). Bedrock exposures are few because of glacial deposition. Glacial deposits of till and some areas of stratified drift overlie most of the bedrock.

Glacial drift thickness in the Mirror Lake area varies from 0 to $55 \mathrm{~m}$, and consists mainly of silty and sandy till, with numerous cobbles and boulders (Hsieh and others, 1993). The hillsides west and northwest of Mirror Lake consist mainly of silty till about $10 \mathrm{~m}$ thick with discontinuous kame terraces at several levels on the hillside. A thick moraine ( $55 \mathrm{~m}$ thick) is north of the lake at well TR1 (fig. 2). In the valley between Mirror Lake and Hubbard Brook, deltaic sand and gravel stratified-drift deposits have been identified (Winter, 1984).

Two glacial tills in New Hampshire and New England have been mapped and are interpreted to be early and late Wisconsinan age (Koteff and Pessl, 1985). Within each till, weathering characteristics and grain size can vary significantly, but in general, the late Wisconsinan-age tills appear to be more extensively weathered and contain more silt and clay than the early Wisconsinan-age tills.

Bedrock exposures in New Hampshire typically correspond to erosional surfaces from the last glaciation. Erosional processes and their topographic locations include glacial plucking on the lee sides of hills, scraping of ridges, and polishing of glacial pavements on some hilltops (Barton, 1996). The Mirror Lake area has few bedrock exposures. 


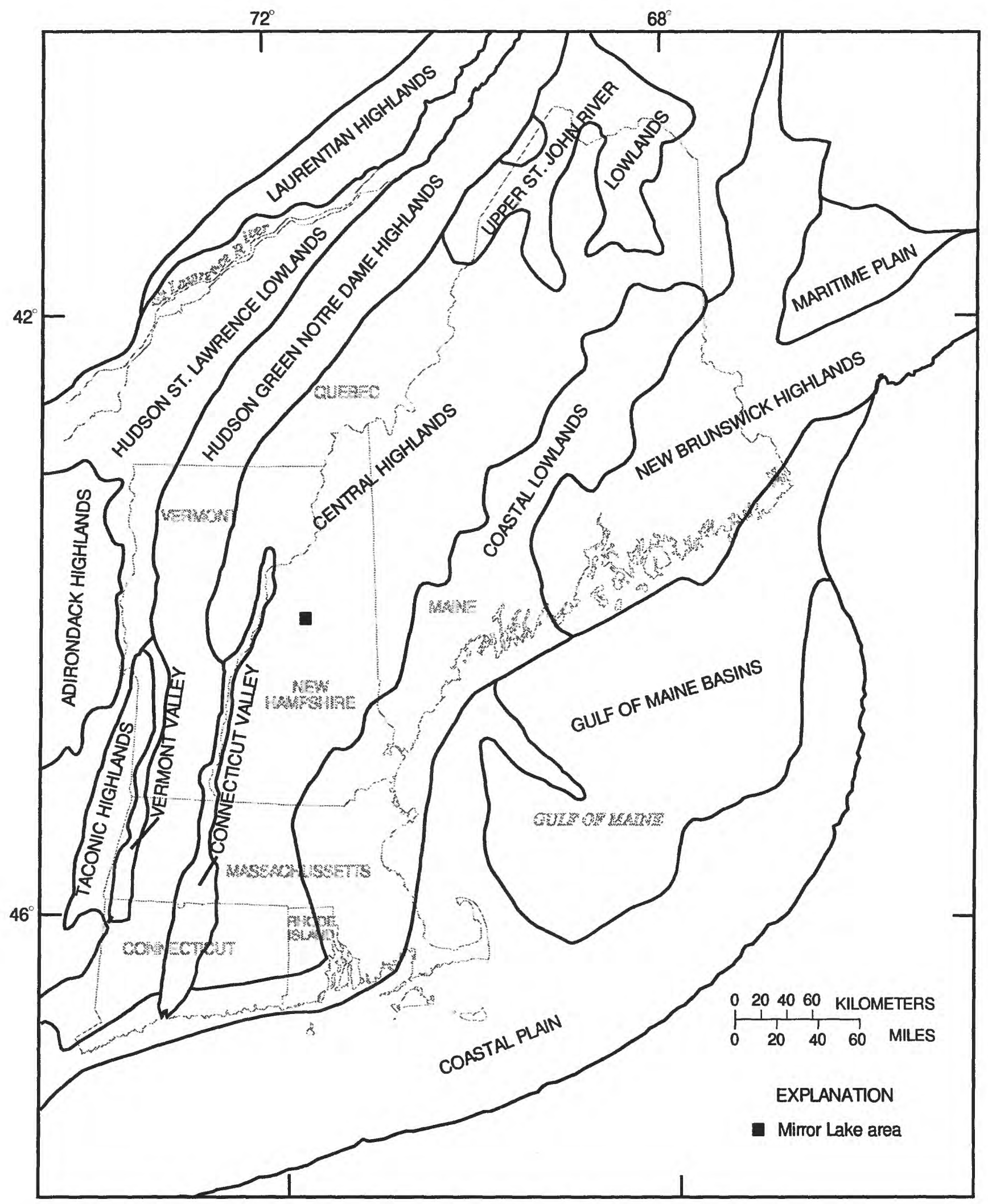

Figure 1. New England physiographic provinces and location of Mirror Lake area, Grafton County, New Hampshire. Modlfied from Denny (1982). 
(A) Individual wells and borings

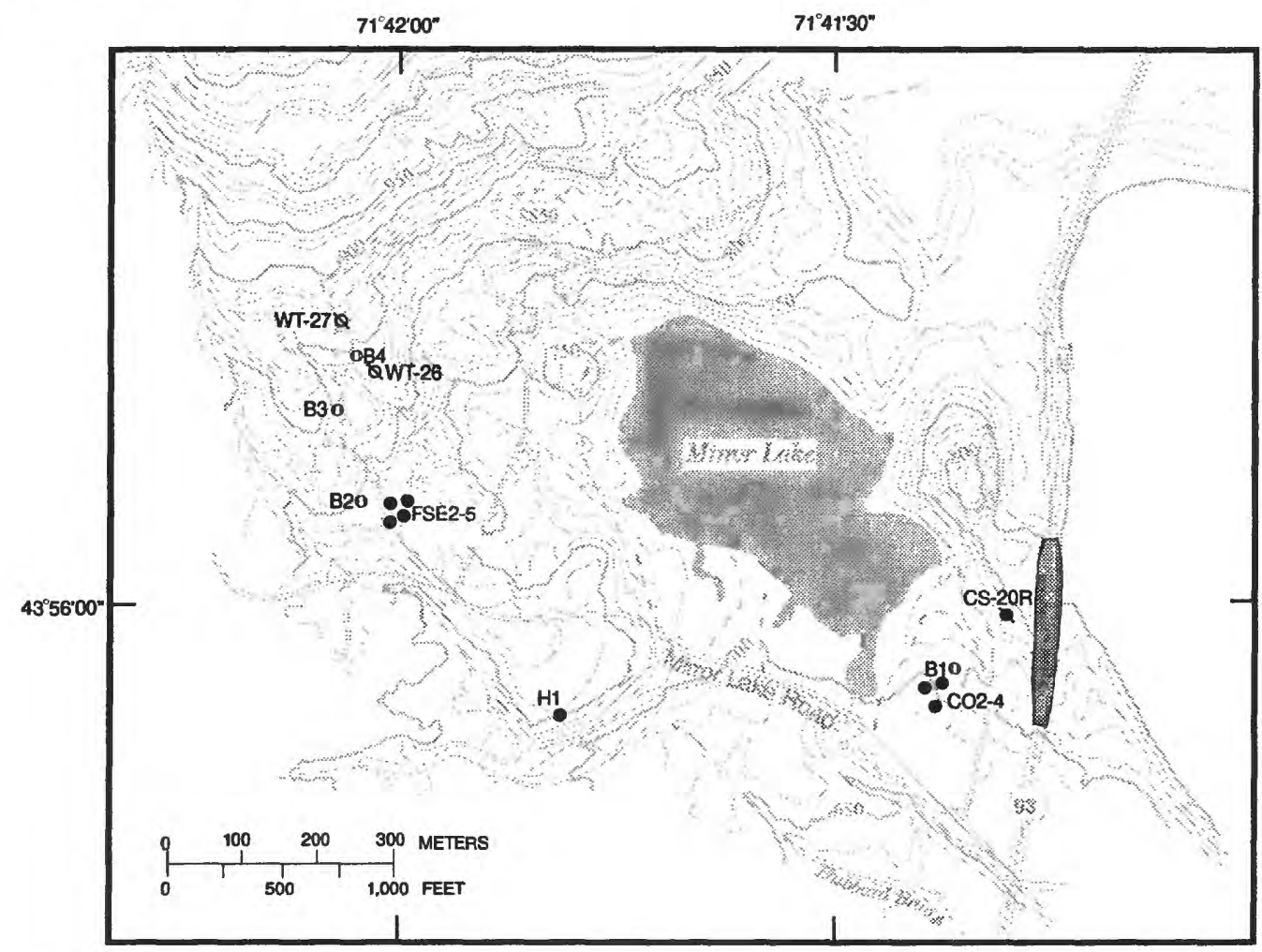

(B) Well clusters

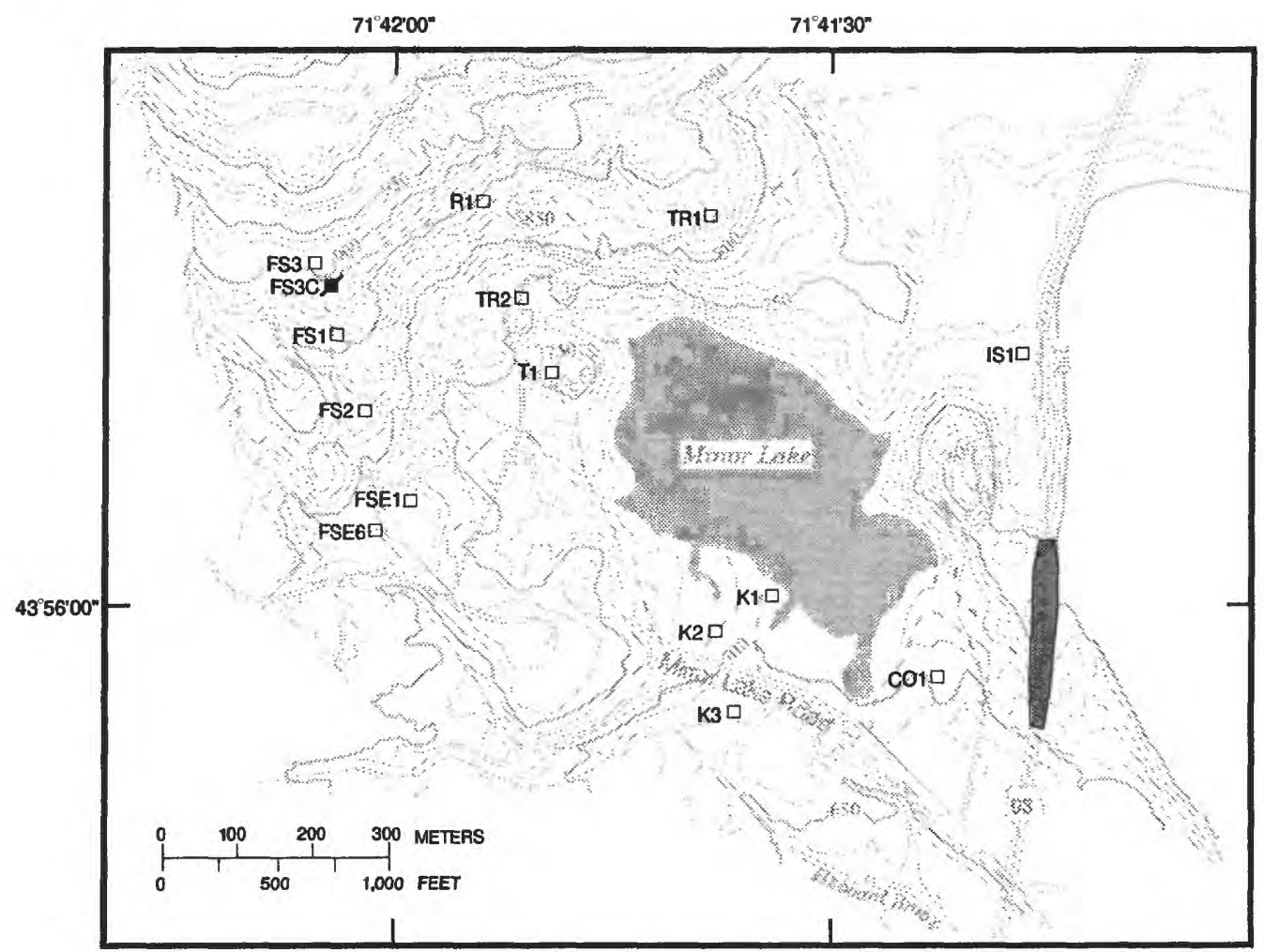

\begin{tabular}{|cl|}
\hline & EXPLANATION \\
& Bedrock outcrop \\
\hline B2 & Test hole and identifier \\
K2 & Well and identifier \\
FS3C & $\begin{array}{c}\text { Shallow bedrock well } \\
\text { and identifier }\end{array}$ \\
H1 & $\begin{array}{c}\text { Deep bedrock well and } \\
\text { identifier }\end{array}$ \\
IS1 & $\begin{array}{c}\text { Well cluster and } \\
\text { identifier }\end{array}$ \\
FS3C & $\begin{array}{c}\text { Shallow bedrock } \\
\text { well cluster and } \\
\text { identifier }\end{array}$ \\
\hline
\end{tabular}

CONTOUR INTERVAL IN FEET (IRREGULAR) NATIONAL GEODETIC VERTICAL

Figure 2. Location of $(A)$ Individual wells and borings, and $(B)$ well clusters In the Mirror Lake area, Grafton County, New Hampshire. 
Preglacial weathered bedrock has been largely removed by the scouring of glacial ice. A few locales, with sections of deeply weathered bedrock indicative of preglacial weathering, have been found in New Hampshire (Goldthwait and Kruger, 1938). At some of these locations, thin seams of unconsolidated till have penetrated far into the rock mass. Injection of till into the shallow bedrock could locally affect vertical permeability and recharge to the bedrock; however, no examples of deeply weathered bedrock are visible in outcrops of the Mirror Lake area or in drill-core samples beneath the till cover (Winter, 1984). It is possible that some undetected preglacial weathered zones are present.

Extrapolation of regional bedrock trends suggest that the Mirror Lake area is underlain by pelitic schist of the lower Silurian Rangeley Formation (Lyons and others, 1986). The pelite underwent multiple folding and metamorphism during the Acadian Orogeny (middle Devonian), to a low sillimanite grade (Hsieh and others, 1993). The schist of the Rangeley Formation is extensively intruded by the Concord Granite of late Devonian age. In turn, the Rangeley Formation and Concord Granite are cut by pegmatite dikes of unknown age. All three rocks are cut by lamprophyre dikes of Middle Jurassic to Early Cretaceous age. A detailed description of the four rock types is given by Barton (1996).

\section{Well-numbering System}

There are five types of wells in the Mirror Lake area; two types of glacial-drift wells and three types of bedrock wells. The prefix attached to the well name denotes location of well. The suffix applied to the well name indicates the vertical positioning of well opening. The nomenclature used to identify wells in this report is unique to this study and does not conform to methods established by the USGS, Ground-Water Site Inventory (GWSI) data base.

Wells are located in clusters or individually. Wells located in clusters are given an alphabetic prefix named after the site name. For example, all wells located at Forest Service Site 3 have a prefix FS3, which corresponds to the site name, FS3. All wells located individually (not part of a cluster of wells) are water- table wells and are denoted with a "WT" prefix. Watertable wells have screens that intersect or are close to the water table.

Wells screened in glacial drift are of two types: (1) water-table wells, and (2) piezometers. Water-table wells are designated with a "WT" prefix if located individually or a "WT" suffix if located in a cluster. For individually located water-table wells, a numeric suffix follows the "WT" to indicate the order in which the well was installed. For example, well name WT-27 is the 27 th individually located water-table well installed. For water-table wells located in a cluster, a cluster name precedes the "WT" suffix. For example, water-table well FS3-WT denotes a water-table well located at the FS3 cluster. Piezometers have screens located below the water table. Their screens (usually $0.6 \mathrm{~m}$ long) are isolated from other parts of the aquifer by grouting the borehole annulus above the screen. Piezometers have a numeric suffix that indicates the bottom of the its screen below land surface, in feet. For example, drift piezometer FS3-29, located at FS3 cluster, has a total depth of 29 feet below land surface.

Wells in bedrock are of three types: (1) shallow bedrock wells with a short open hole $5 \mathrm{~m}$ long, examples include FS3C and CS-20R; (2) bedrock wells with one long open hole (tens of meters in length); and (3) bedrock wells divided into zones with inflatable packers. Shallow bedrock wells and bedrock wells with no packers have no attached suffix, whereas bedrock wells with packed-off zones have an alphabetic suffix depending on the relative position of the zone (Paul Hsieh, U.S. Geological Survey, written commun, 1990). The zones are labelled in ascending order from depth below land surface such that the upper packed-off zone of bedrock is designated with an "-A", the middle zone with a "-B", and the lower zone with a "-C".

In this report, bedrock well data are provided for the entire open hole regardless if the well contained packers. All bedrock wells reported in appendix A except the shallow bedrock wells (FS3C and CS-20R) contained packers for some duration of the study including FS3, FS1, R1, TR1, FSE6, FSE1, FSE2, FSE3, FSE4, FSE5, T1, CO1, CO2, and TS1. Packer designation are specified in text only when needed to differentiate relative vertical positioning in the well. 


\section{Acknowledgments}

This research was funded by the U.S. Geological Survey Toxics Waste Program. The author appreciates the cooperation of the U.S. Forest Service and it's employees at the Hubbard Brook Experimental Forest, which is operated and maintained by the Northeastern Forest Experimental Station, U.S. Department of Agriculture, Forest Service, Radnor, $\mathrm{Pa}$. The author also wishes to thank his colleagues at the Mirror Lake Fractured-Rock Research Site for their assistance, most notably Carole Johnson of the U.S. Geological Survey, New Hampshire - Vermont District for helping in lithologic classification of the shallow bedrock.

\section{LITHOLOGIC PROPERTIES}

Unconsolidated glacial drift and shallow bedrock are the hydrogeologic units that influence recharge to the lower zones of the bedrock, below the uppermost 5 $\mathrm{m}$ of bedrock. The following sections describe methods and results of investigation of the lithologic properties of these units.

\section{Methods}

Test drilling was used to define stratigraphy in bedrock-recharge areas adjacent to Mirror Lake. Test holes were drilled by use of hollow-stem auger in shallow holes and spin-casing drilling in deep holes (greater than $10 \mathrm{~m}$ ). Spin-casing drilling uses a tricone roller bit attached inside a $11.2-\mathrm{cm}$ core barrel and casing. The tricone roller bit can be removed to allow lithology samples to be taken by use of a Waterloo ${ }^{3}$ core sampler in the glacial drift and a rock core barrel in the bedrock. Waterloo core samples were used to characterize drift stratigraphy by driving a tube into undisturbed sediments at 1.52 meter intervals. Continuous rock cores were taken from the uppermost 5 meters of bedrock to characterize lithology and fractures by cutting into the bedrock with a diamond bit.

Mineralogic composition of five lithologic samples (two till and three bedrock) were analyzed by x-ray diffraction (John Neil, U.S. Geological Survey, written commun., 1994-95). X-ray diffraction or diffractometry is a method of determining the

\footnotetext{
${ }^{3}$ Any use of trade, product, or firm names is for descriptive purposes only and does not imply endorsement by the U.S. Government.
}

characteristic atomic spacing in crystalline and microcrystalline materials found in sediments and rock. The minerals can be identified by matching patterns with those of standards prepared from known minerals, and a list can be made of mineral phases found in the sample (Richard O. Hawkinson, U.S. Geological Survey, written commun., 1991).

Stratigraphic interpretation was facilitated by logging wells with a natural-gamma-radiation tool. Natural-gamma logs measure the total gamma radiation, measured in counts per second (cps) from the surrounding formations. Gamma-emitting radioisotopes are natural products of uranium and thorium decay series and potassium -40 . These elements are distributed in the glacial deposits primarily based on grain size because the parent rock of the stratified drift and tills are the same. Fine-grained sediments contain a greater proportion of uranium, thorium, and potassium than coarse-grained sediments. In bedrock, the distribution of these elements are not as clearly understood; however, the igneous intrusive rocks are known to contain higher radioactivity than metamorphic rock such as schist (Francis Hall, University of New Hampshire, oral commun., 1990).

\section{Results}

Lithologic and natural-gamma logs from the glacial drift and shallow bedrock found during test drilling in the Mirror Lake area are shown in appendix B. The locations of the test wells and borings are shown in figure 2.

\section{Glaclal Drift}

The glacial deposits observed during the testdrilling program for this study include stratified drift and two types of glacial till, lodgment, and ablation.

Discontinuous stratified-drift deposits in the form of kame terraces cap glacial till at several levels along the western hillside above Mirror Lake. Deposits in kame terraces are primarily composed of moderately sorted medium-grained sands and typically are less than 5 meters thick. The kame-terrace sands are believed to directly overlie bedrock in a small area around site FS2 and B3 (fig. 2). Most well clusters along the western hillside above Mirror Lake are situated on kame or esker terraces because the terraces provide a level drilling platform (appendix B2 and B4). 
The predominant glacial deposit along the western and northwestern hillside above Mirror Lake is a lodgment till that grades in weathering from an upper brown weathered till to a slightly weathered olive gray till (appendix B2). The weathered parts can contain mottled material. The lodgment till is compact and poorly sorted, with clay to cobble size sediments. It has a silt matrix. This till may also contain large boulders. No natural fractures were observed in any of the core samples.

Ablation till is present at Mirror Lake. Ablation till contains water-washed material that is better sorted than the lodgment till. Ablation till overlies the bedrock surface at FS1 and B4 (appendix B2; fig. 2) and between two lodgemont till layers at FSE (appendix B2; fig. 2).

The till to the east of Mirror Lake is an ablation till (appendix B1 and B3; fig. 2). The till is thin (less than 5 $\mathrm{m}$ thick). Ablation till probably dominates the low-lying area around Mirror Lake because mass wasting of glacial ice was most likely to have been concentrated there, as Mirror Lake occupies a kettle hole.

The percent distribution of silt to small gravel-size sediments from the principal glacial-drift units found in the Mirror Lake area is shown in figure 3. The grainsize distribution of the kame-terrace deposits (FS3C, depth $1.5 \mathrm{~m}$ ) shows a smooth curve that steeply drops off in the medium-grained sand range indicating a moderately sorted deposit. In contrast, the lodgment-till deposits are more poorly sorted and show a linear diffuse trend in grain-size distribution (samples from WT-27). Brown weathered lodgment till (sample WT27, depth 2.8-3.7 m) contains 8 percent more silt particles than the slightly weathered olive-gray lodgemont till (sample WT-27, depth 5.5-5.6 m). The ablation till (B1, depth $3 \mathrm{~m}$ ) has 7 percent more sandsize grains than the lodgemont till (sample WT-27, depth 5.5-5.6 m).

Grain-size distribution of two till samples from a carbonate and shale parent-rock terrain are included in figure 3 (see Ohio ground-moraine samples) to contrast against tills from crystalline terrain (see Mirror Lake samples). Grain-size distribution of till samples from the Mirror Lake area are within the range of grain-size distribution from ground moraine in Ohio (Strobel, 1993); however, on average, they contain less silt (fig. 3). Till sample GM \#1-9 from Ohio contains about 60 percent more silt than those from Mirror Lake. Till sample GM \#1-9 is derived from a gray, unweathered till that was possibly subjected to eluviation of silts and clays from an overlying weathered zone (Strobel, 1993).

Although there are grain-size differences between the ablation and lodgment tills, their mineralogic composition is similar based on $\mathrm{x}$-ray diffraction of an ablation-till sample at $\mathrm{Bl}$ and a lodgment-till sample at WT-27. The predominant mineral is quartz. Minor minerals include albite, intermediate microcline, and illite. Trace minerals include an amphibole. In the lodgment-till sample, chlorite was also detected.

\section{Shallow Bedrock}

Rocks found during drilling can be differentiated into two major classes: the host metamorphic rocks and a variety of igneous intrusive rocks. The metamorphic rocks are of the Rangeley Formation and include moderately to strongly foliated schist and moderately foliated gneiss. The igneous intrusives include several types of granite, pegmatite, and migmatite. The granites are part of the Concord granite. The detailed description of rock types in the following paragraph is modified from Lyons and others (1989) and Barton (1996).

Metamorphic rocks were found at each bedrock core hole except B2 in the FSE well field (fig. 2) (this bedrock hole was drilled less than $1 \mathrm{~m}$ into the bedrock) and FS3C (appendix B2 and B4). The metamorphic rocks are black and white, medium to coarse grained, thinly laminated $(5-25 \mathrm{~mm})$ pelitic schist. They are characteristic of rocks from the Rangeley Formation. As shown on the state of New Hampshire bedrock geologic map (Lyons and others, 1986), the Rangeley Formation is divided into lower and upper parts, differentiated by weathering features and color in the Mirror Lake area (Barton, 1996). The lower part of the Rangeley exhibits non-rusty weathering, whereas the upper part of the Rangeley exhibits rusty weathering. The lower and upper parts have similar mineralogy and include feldspar, quartz, biotite, muscovite, sillimanite, and local occurrences of fine-grained garnet and (or) minerals with sulfidic chemistry.

The predominant igneous intrusive rock found during test drilling is a two-mica granite. The two-mica granite occurs at B2, B4, FS3C, and CS-20R (appendix B2 and B4). It is medium grained, equigranular, gray to light gray, and contains quartz, feldspars, muscovite, biotite, chlorite, and small amounts of dark purple-red 


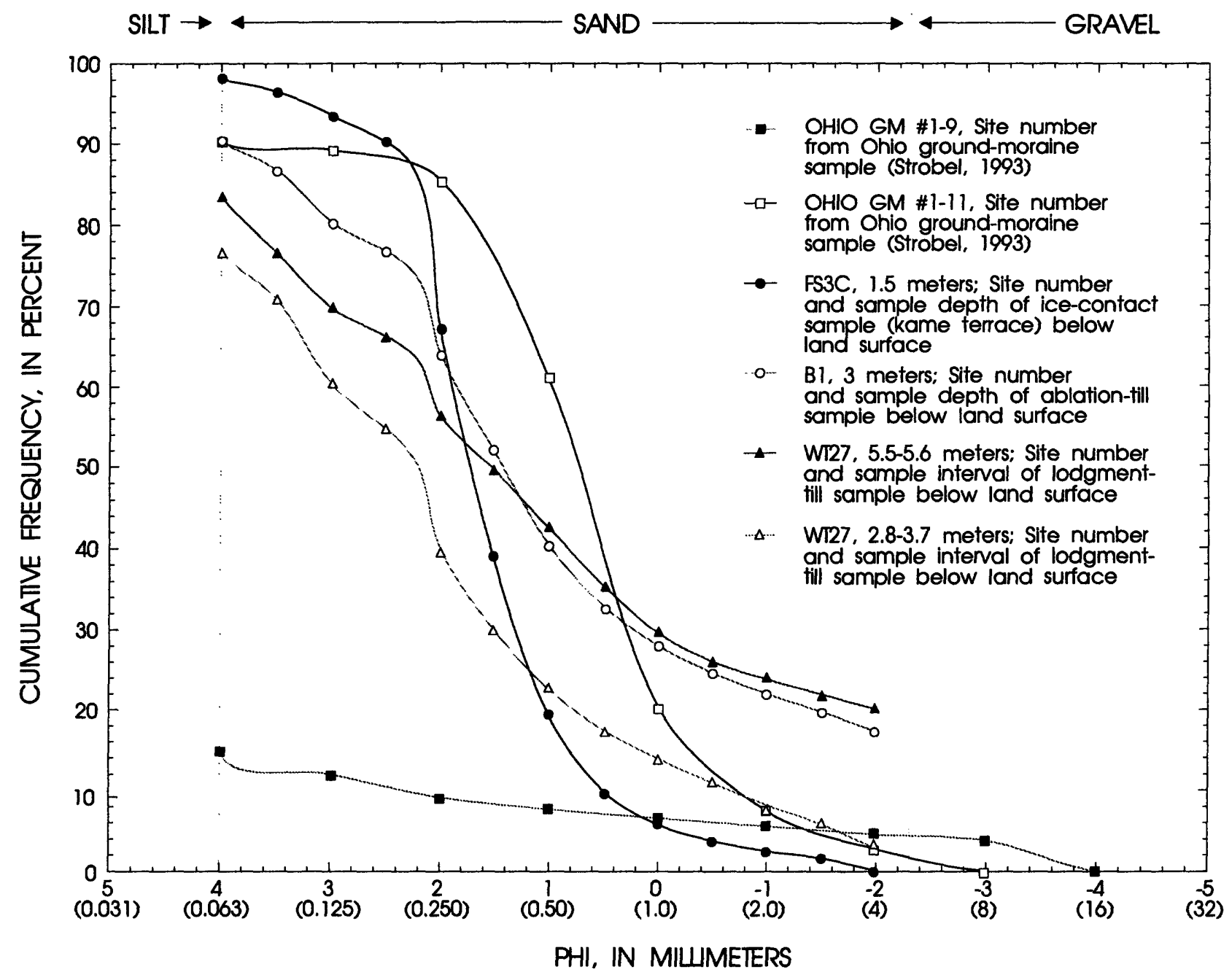

Figure 3. Grain-size analysis from representatlve glaclal-drift samples in Mirror Lake, New Hampshire. (See figure 2 for Mirror Lake site locations.)

garnet. Plagioclase feldspar is the dominant feldspar; orthoclase feldspar is relatively minor. The two-mica granite is similar to the Concord granite, which is defined as an anatectic, two-mica granite, locally grading into tonalite (Lyons and others, 1986, and Barton, 1996).

Test drilling found two other types of granite: a biotite-rich granite; and a leucocratic granite. Biotiterich granite occurs at only one site, $\mathrm{Bl}$ (fig. 2, appendix B1). It is weakly foliated, dark gray in color, and contains quartz, feldspars, and abundant amounts of biotite. It also contains a 1 to $2 \mathrm{~mm}$ thick green calcite crystals. Leucocratic granite was found at wells FS3C and CS-20R (fig. 2, appendix B4). At FS3C the granite is highly weathered and broken. At CS-20R it is slightly weathered and highly fractured. The leucocratic granite is a light-colored felsic rock containing quartz and feldspars, some muscovite, but few dark micas.
Pegmatite was found at test boring B3 and well CS-20R (appendix B1 and B4). The pegmatite is white, coarse-grained, plagioclase-rich, and contains biotite, muscovite, and quartz.

No saprolite or significant weathered zone was found at any of the bedrock core holes. This supports observations by Goldthwait and Kruger (1938) on weathering characteristics of bedrock exposures in New Hampshire and indicates that glacial scouring has removed any saprolitic rocks from the area. With the exception of rubble zones containing broken up, less competent bedrock at FS3C, all bedrock found during drilling is competent or structurally solid.

The granite and schist have similar mineralogy, predominantly quartz with feldspars and micas and no detectable trace minerals. The mineralogy is based on $\mathrm{x}$ ray diffraction of two leucocratic granite samples from 
Table 1. Summary of fracture frequencles from shallow to deep bedrock intervals, Mirror Lake area, Grafton County, New Hampshire

$[\sim$, approximate value; $\cdots$, no data]

\begin{tabular}{|c|c|c|c|c|c|c|c|c|c|}
\hline $\begin{array}{l}\text { Test } \\
\text { hole }\end{array}$ & $\begin{array}{c}\text { Core } \\
\text { length } \\
\text { (in } \\
\text { meters) }\end{array}$ & $\begin{array}{c}\text { Total } \\
\text { number } \\
\text { of } \\
\text { fractures }\end{array}$ & $\begin{array}{c}\text { Fracture } \\
\text { frequency } \\
\text { (number } \\
\text { per } \\
\text { meter) }\end{array}$ & $\begin{array}{c}\text { Maximum } \\
\text { fracture } \\
\text { frequency } \\
\text { over 5- } \\
\text { meter } \\
\text { interval }\end{array}$ & $\begin{array}{l}\text { Fracture } \\
\text { maximum } \\
\text { dip angle }\end{array}$ & $\begin{array}{l}\text { Fracture } \\
\text { minimum } \\
\text { dip angle }\end{array}$ & $\begin{array}{c}\text { Fracture } \\
\text { median } \\
\text { dip angle }\end{array}$ & $\begin{array}{l}\text { Major } \\
\text { rock type }\end{array}$ & $\begin{array}{c}\text { Estimated } \\
\text { hydraulic } \\
\text { conduct- } \\
\text { ivity } \\
\text { (meters per } \\
\text { second) }\end{array}$ \\
\hline
\end{tabular}

Shallow Bedrock (within uppermost 5 meters of rock)

$\begin{array}{llllllllll}\text { B1 } & 1.9 & 6 & 3.2 & \ldots & 60 & \sim 0 & \sim 0 & \text { Granite } & -. \\ \text { B2 } & 0.6 & 2 & 3.6 & -- & 32 & 32 & 32 & \text { Granite } & -. \\ \text { B3 } & 2.8 & 19 & 6.8 & -- & 79 & 9 & 36 & \text { Granite } & -- \\ \text { B4 } & 3.1 & 23 & 7.4 & \ldots & 90 & 9 & 17 & \text { Schist } & -- \\ \text { FS3C } & 4.5 & 58 & 12.9 & \ldots & 80 & 10 & 35 & \text { Granite } & 14.0^{-9} \\ \text { CS-20R } & 6.1 & 14 & 2.3 & -- & 70 & 11 & 30 & \text { Schist } & 18.5^{-7}\end{array}$

Deep Bedrock ${ }^{2}$ (below uppermost 5 meters of rock)

\begin{tabular}{|c|c|c|c|c|c|c|c|c|}
\hline FS1 & 136.9 & 177 & 1.3 & 3.8 & -. & -- & - & $\cdots$ \\
\hline FS2 & 151.5 & 174 & 1.2 & 4.2 & - & -- & -. & - \\
\hline FSE4 & 228.4 & 113 & 0.5 & 3.0 & - & - & $\cdots$ & $\cdots$ \\
\hline $\mathrm{CO} 1$ & 166.5 & 37 & 0.2 & 1.2 & - & -- & - & - \\
\hline PV & 186.6 & 52 & 0.3 & 2.4 & - & -- & $\cdots$ & -- \\
\hline
\end{tabular}

${ }^{1}$ Obtained from slug test and analyzed by methods of Bouwer and Rice (1976).

${ }^{2}$ Data on deep bedrock from Paillet and Kapucu (1989).

FS3C (10.55-10.67 $\mathrm{m}$ below land surface and 11.97$12.23 \mathrm{~m}$ below land surface) and one schist sample from CS-20R (4.42-4.57 $\mathrm{m}$ below land surface). The three rock samples differ in degree of weathering with the schist the least weathered rock and the granite (11.97$12.23 \mathrm{~m}$ interval) the most weathered rock. The most weathered granite sample appears to contain less muscovite and calcium feldspar than the least weathered granite sample $(10.55-10.67 \mathrm{~m})$.

The majority of fracture faces on shallow bedrock cores contain some degree of iron-hydroxide staining. Those fracture faces with no staining are attributed to mechanical breaks of the bedrock core during the drilling process. Iron-stained fracture faces also contain some silt indicating either decomposition of the bedrock mass or downward movement of fine sediments from the overburden. As a general observation, fracture openings must be small because bedrock-core recovery is high.

Fractures are found in all rock types and typically near bedrock contacts. However, the leucocratic granite appears to be more brittle than the other rocks cored because it is heavily fractured. The shallow bedrock at core hole CS-20R is the least fractured. This contrast in fracture frequencies between FS3C to the west and
CS20-R to the east corroborates with preliminary findings (F.L. Paillet, U.S. Geological Survey, oral commun., 1993) that show bedrock near CS-20R, by the $\mathrm{CO}$ well field on the east side of Mirror Lake (fig. 2), are less fractured than rocks located to the west of Mirror Lake.

Observations of fracture distributions from a limited number of bedrock cores from the study area indicate the shallow bedrock is moderately fractured and the fracture frequency of shallow intervals exceeds fracture frequencies from deep intervals. Fracturesummary statistics are shown in table 1 for the shallowbedrock holes (uppermost $5 \mathrm{~m}$ of bedrock) and selected deep bedrock test holes (below the uppermost $5 \mathrm{~m}$ of bedrock) in the Mirror Lake area (fig. 2). Fracture frequencies in the shallow bedrock range from 2.3 to 12.9 fractures per meter for various cored intervals. This frequency exceeds fracture frequencies reported by Paillet and Kapucu (1989) from bedrock intervals below the uppermost $5 \mathrm{~m}$ of bedrock. Because the holes sampled by Paillet and Kapucu (1989) cover a large interval of the bedrock, and the shallow bedrock holes cover a small interval, only semi-quantitative comparisons can be made between the uppermost $5 \mathrm{~m}$ of bedrock and the lowermost intervals. The maximum 


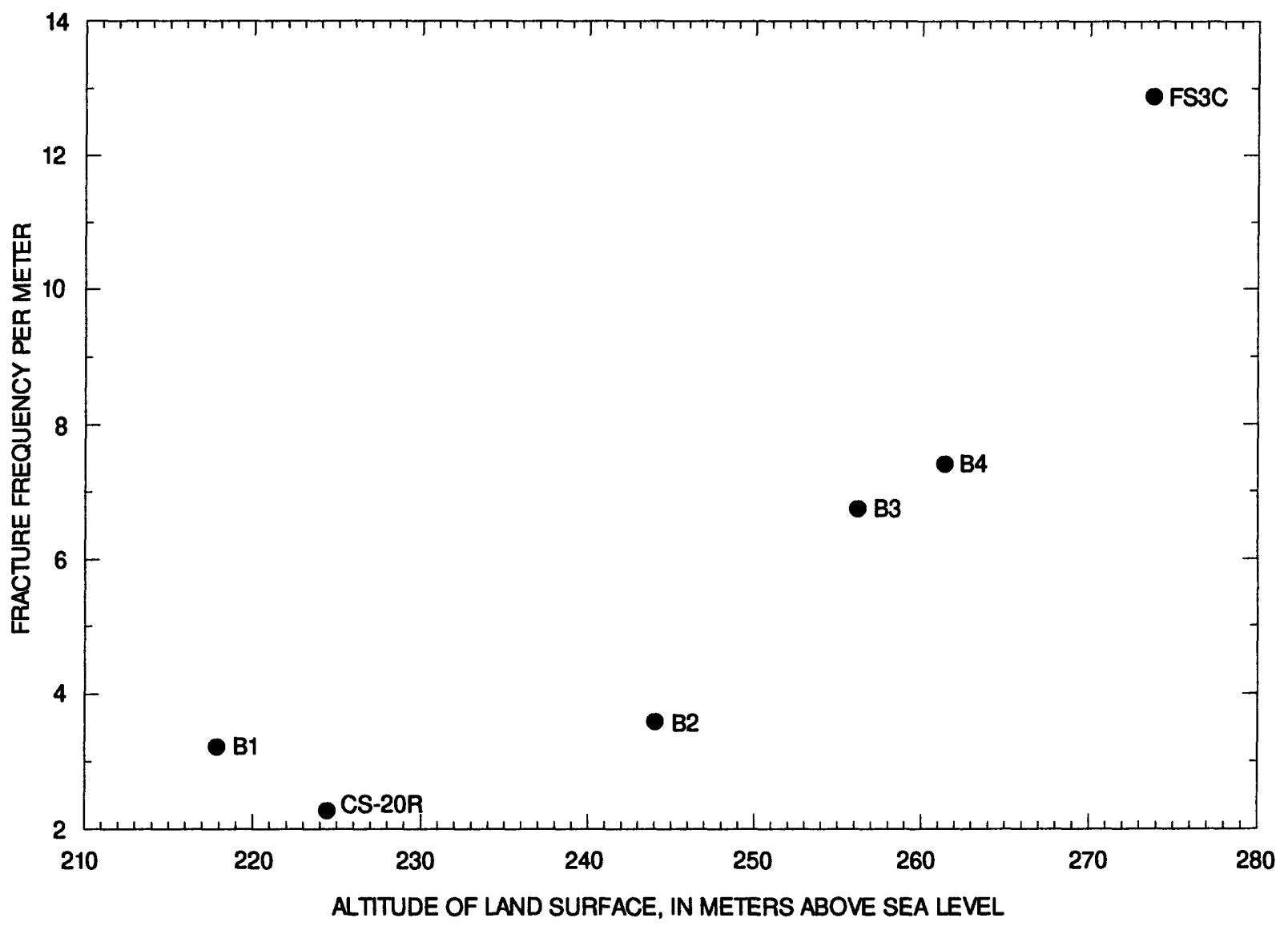

Flgure 4. Relation between shallow bedrock fractures and altitude of land surface of text holes in Mirror Lake, New Hampshire. (See figure 2 for locatlon of text holes.)

fracture frequency reported by Paillet and Kapucu (1989, fig. 19) over a 5 -meter interval is 4.2 fractures per meter at a depth of $80 \mathrm{~m}$ at well FS2.

Although data are limited, there appears to be a possible relation between shallow-bedrock-fracture frequency and topographic relief. Shallow-bedrockfracture frequencies increase with altitude above sea level (fig. 4). The highest fracture frequency is observed at FS3C and the least at CS-20R, which corresponds to topographic highs and lows. Additional data is needed to substantiate this preliminary observation.

Topographic controls on fracture frequency have been studied in sedimentary terrain by Wyrick and Borchers (1981) and on water yield in glaciated (Knopman and Hollyday, 1993) and unglaciated environments (LeGrand, 1967).

Two possible explanations offered here are preliminary conceptual models of the apparent observed fracture frequency. The first is that preferential glacial erosion in valleys caused the removal of additional fractured bedrock in valleys, hence relatively more shallow fractures occur on hillsides than in valleys. The second is that high tensional stresses on hillsides produce high-angle fractures in bedrock on hillsides because the rock masses along hillsides lack lateral support from the adjacent rock masses in the valley.

\section{HYDRAULIC PROPERTIES}

The principal differences in hydraulic properties between the glacial drift and shallow bedrock are related to the degree of induration ${ }^{4}$. The glacial drift is an unconsolidated deposit with primary porosity ten times that of the bedrock. Over large scales, groundwater flow and transport is generally through individual pore spaces. The shallow bedrock has little primary

${ }^{4}$ Induration is defined as the process of hardening of sediments or other rock aggregates through cementation, pressure, heat, or other cause. The glacial drift has been subjected to lesser amounts of induration than the bedrock. These differences in induration between the glacial drift and bedrock affect the amount of primary porosity and consequently their hydraulic properties. 
porosity. Wood and others (1994) determined that the primary porosity of a non-fractured, non-weathered granite in the Mirror Lake area averages 1.5 percent. Ground-water flow and transport in crystalline bedrock is primarily through fractures. These differences in primary porosity affect aquifer responses to hydraulic tests.

\section{Methods}

Estimates of values of hydraulic properties were made from a variety of techniques and methods including permeameter and grain-size analyses done on samples of glacial drift, two types of slug-test analyses (Bouwer and Rice, 1976; and Cooper and others, 1967), and aquifer tests analyzed by methods described by Neuman (1975). The various techniques and methods are briefly described in the following paragraphs.

The permeameter, grain size, slug, and aquifer tests were used to estimate hydraulic properties. Each type of analysis yields hydraulic estimates for progressively larger sample volumes; from small (permeameter and grain-size analyze), middle (slug test), and large (aquifer test) samples. Small samples of glacial drift were tested through characterization of grain-size properties and water-transmitting capabilities over a finite-sample volume. Slug tests were conducted by applying an instantaneous rise (forward test) or decline (reverse test) to the water level in a well while recording the change in head. Aquifer tests were conducted by recording the transient pressure response in water levels of observation wells to ground-water withdrawals over areas of several meters to perhaps hundreds of meters.

Permeameter and grain-size analyses of glacialdrift samples differ in that permeameter analyses are performed on a generally undisturbed core sample, whereas grain-size analyses are performed on a more disturbed sample. For permeameter analyses, the core sample is subjected to a constant flow rate while differential fluid pressures are measured in three directions, called triaxial tests (Olsen and others, 1985). Triaxial tests were used to determine the ratio of horizontal to vertical hydraulic conductivity, to detect the presence of secondary permeability or fractures, and to evaluate the disturbance of the core from the extraction process, thereby evaluating the appropriateness of the core sample in representing actual subsurface conditions. Grain-size analyses are performed by dry sieving sediments and analyzing the statistical distribution of grain sizes. Estimates of hydraulic conductivity are derived from a disaggregated sample using an empirical relation described by Olney 5 (1983). Because the empirical relations between representative grain size and hydraulic conductivity developed by Olney (1983) were based on a more homogeneous, well-sorted deposit than that characteristic of some of the glacial tills in the Mirror Lake area, this method overestimates hydraulic conductivity for the lodgment till.

Results of slug tests were done on forward (insertion of slug) and reverse (removal of slug) test results. Estimates were made by use of two methods-Bouwer and Rice (1976) and Cooper and others (1967). Data analyses were facilitated by use of a parameterestimation method described in Geraghty and Miller (1991). Parameters needed for analysis include radius of well, effective radius of test, saturated thickness, screen length, and static height of water in well. All parameters except effective radius of test can be quantified and easily obtained, whereas the effective radius is determined by use of an empirical relation established by Bouwer and Rice (1976). The effective radius is the radius, measured from the well outward into the aquifer, that is affected by a pressure response when the slug is inserted or removed in the well and it is highly dependent on aquifer properties.

Hydraulic-conductivity values determined by use of the Bouwer and Rice (1976) method appear to be more representative than those values determined by use of the Cooper and others (1967) method. The Bouwer and Rice method of slug-test analysis is based on the Thiem equation for steady-state flow to a well and incorporates the effect of the geometry of the ground-water system through the use of an empirical relation between the system response and the effective radius of test. This method also incorporates the effects of partially penetrating wells under unconfined conditions, which are present at Mirror Lake. Cooper and others (1967) employs an analytical approach by use of solving a transient equation of ground-water flow subject to boundary conditions of the test, which

\footnotetext{
${ }^{5}$ Olney (1983) uses a representative grain size of $D_{10}$ where 10 percent of the sample is of smaller grains and 90 percent is of larger grains. The empirical relation used is Hydraulic conductivity $=$ $2,100(10)^{-0.655 b_{10}}$
} 
include the assumptions that wells are fully penetrating and screened in a confined aquifer. Although the Bouwer and Rice technique is more appropriate than Cooper and others (1967) to analyze slug-test results from the Mirror Lake area, values of hydraulic conductivity estimated with the Cooper and others (1967) analysis are also provided to allow for a comparison between the two methods and the incorporation of hydraulic-conductivity estimates from Wilson (1991), which were determined by application of the method of Cooper and others (1967).

Aquifer tests were performed at two well clusters (FS3C and CO) shown in figure 2. Drift stratigraphy and shallow bedrock lithology differ at the two well clusters and offer an opportunity to study aquifer tests to two different settings (appendix B4 and B1). The deepest glacial-drift well (FS3C-29 and C01-18) was pumped for 1 day at each site and water levels were recorded in adjacent wells to assess the hydraulic connection between the glacial drift and the shallow bedrock. Shallow bedrock water levels responded at both sites to fairly low withdrawals. It was necessary to pump at low rates (less than $1 \mathrm{~L} / \mathrm{min}$ ) with a peristaltic pump because of the low hydraulic conductivity of the glacial till at both sites.

During the aquifer tests, pumpage rates varied by 8 percent at well cluster FS3C and as much as 39 percent at well cluster $\mathrm{CO}$ (fig. 2). To compensate for variations in pump rates, estimates of aquifer properties were made for ranges of rates experienced. Although the percent variation of pump rates are high, differences in rates were only $0.02 \mathrm{~L} / \mathrm{min}$ at $\mathrm{FS} 3 \mathrm{C}$ and $0.31 \mathrm{~L} / \mathrm{min}$ at $\mathrm{CO}$. Because of the low initial pump rates, any small change in pump rates caused a large percent change. The sensitivity of estimates of hydraulic properties to these variations in pump rates are negligible at FS3C and relatively small (within 65 percent for estimates of transmissivity) at $\mathrm{CO}$. Therefore, at the FS3C aquifer test, only one constant pump rate was used to estimate properties. For the $\mathrm{CO}$ aquifer test, two different pump rates were used, one for the early (first 100 minutes) part of the test, and one for the remaining part of test.

The Neuman (1975) method of analysis was used to analyze data from the two aquifer tests (FS3C and CO). This method incorporates the effects of anisotropy, partially penetrating wells, and delayed gravity yield, which may be found in unconfined conditions. It is an analytical method that estimates aquifer parameters from a comparison of observed drawdowns to theoretical type curves formulated from dimensionless analytical solutions that are uniquely generated from well, aquifer geometries, and the potential water contribution from delayed storage or yield during the test. Because aquifer tests include a larger volume of sample than slug tests or analysis of individual glacial-drift samples, they provide information on the average directional properties of the aquifer. The generation of type curves and a comparison between data were facilitated by use of a computer program that computes type curves from partialpenetration and potential delayed yield contributions (Geraghty and Miller, 1991).

Hydraulic properties from the shallow bedrock were determined at two shallow bedrock-test wells (FS3C and CS-20R) installed for this study (fig. 2). The two bedrock wells are in different settings. Well cluster FS3C is on a hillside kame terrace feature and is primarily in granitic bedrock. Well CS-20R is on the east side of Mirror Lake near the $\mathrm{CO}$ well cluster and is primarily in schist bedrock. These are the only two wells open to the uppermost $5 \mathrm{~m}$ of bedrock in the Mirror Lake area; all other bedrock wells are sealed by pipe casing in the uppermost $5 \mathrm{~m}$ of bedrock. The construction diagram for the shallow bedrock wells is shown in figure 5.

Estimates of shallow-bedrock hydraulic conductivity were derived from slug tests at wells FS3C and CS-20R and from an aquifer test at well cluster FS3C. Estimates of hydraulic conductivity were also derived from fracture characteristics at FS3C and CS20R by methods described by Snow (1968), who estimated the intrinsic or natural permeability of fractured bedrock by use of the Navier-Stokes ${ }^{6}$ equation. The Navier-Stokes equation describes flow in fractured bedrock based on the analogy of flow between parallel plates with constant aperture. The NavierStokes equation is

$$
k=\left(\frac{N b^{3}}{12}\right) \text {, }
$$

where

\footnotetext{
${ }^{6}$ The Navier-Stokes equation and the parallel plate analogy are also known as the cubic law, which states that because hydraulic conductivity of the bedrock is computed from the cube of the fracture aperture times fracture frequency and properties of the water.
} 


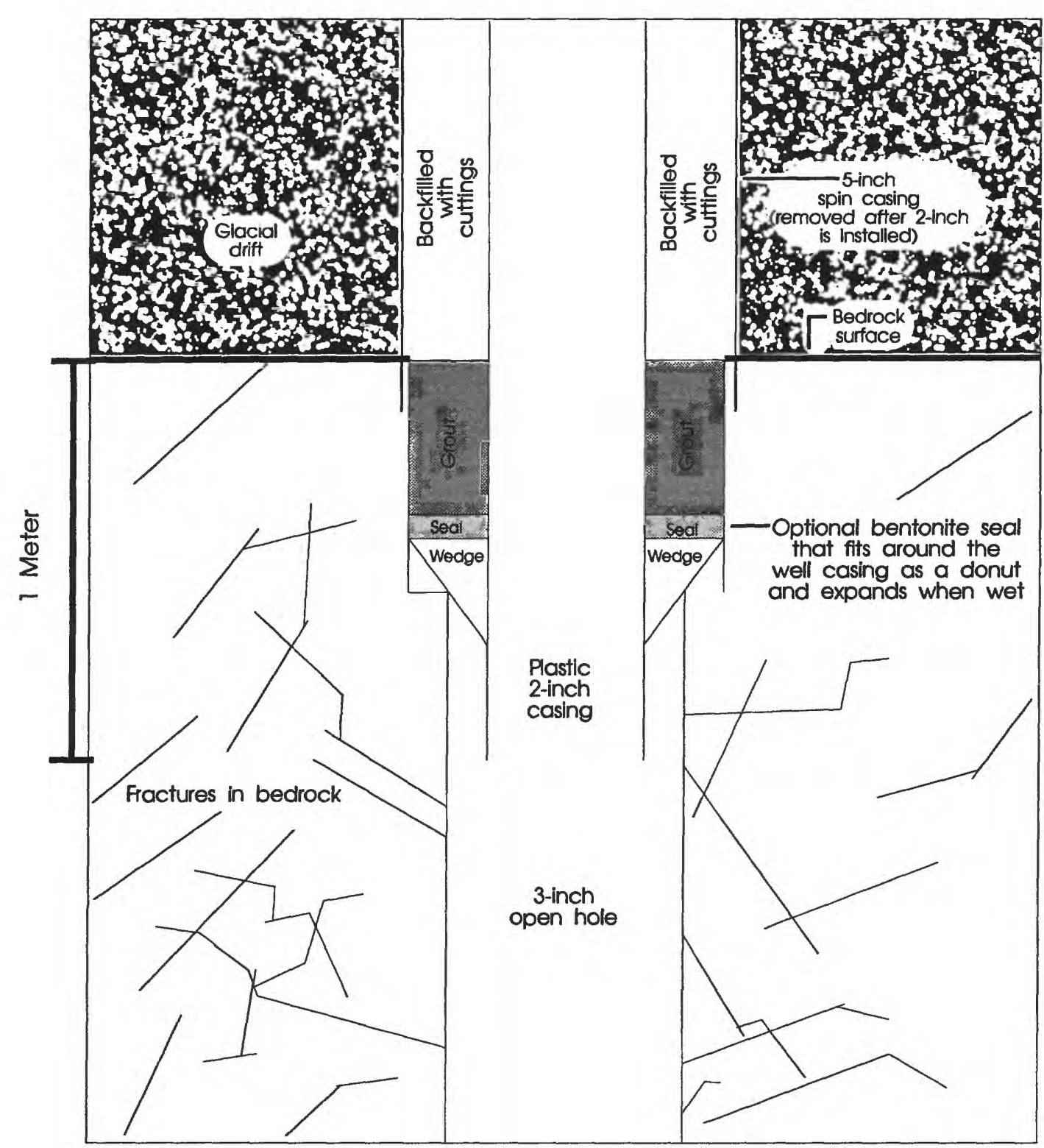

Not to scale

Figure 5. Diagram showing shallow bedrock-well construction.

$k$ is intrinsic permeability,

$N$ is fracture frequency, and

$b$ is fracture aperture.

Intrinsic permeability is related to hydraulic conductivity by the relation

$$
K=k\left(\frac{p g}{u}\right)
$$

where

$p$ is density of water, $g$ is gravity, and

$u$ is viscosity of water.

Fracture frequencies were determined by counting fractures in the bedrock cores drilled for this study and apertures sizes from the 25th, 50th, and 75th percentile of aperture sizes, as determined by Barton (1996), from the bedrock outcrop near CS-20R (fig. 2). These data were used to determine likely hydraulic conductivities of fractured bedrock at FS3C and CS-20R.

Porosity estimates of glacial drift were determined from permeameter tests based on differential weight 
Table 2. Summary of hydraulic conductivity estimated from multiple techniques, Mirror Lake area, Grafton County, New Hampshire

$[--$, no data $]$

\begin{tabular}{|c|c|c|c|c|c|c|c|c|c|}
\hline \multirow{4}{*}{$\begin{array}{c}\text { Well/test } \\
\text { hole }\end{array}$} & \multirow{4}{*}{$\begin{array}{c}\text { Sampled } \\
\text { interval } \\
\text { (meters } \\
\text { below land } \\
\text { surface) }\end{array}$} & \multirow{4}{*}{$\begin{array}{c}\text { Hydro-geologic } \\
\text { unit }\end{array}$} & \multicolumn{7}{|c|}{ Hydraulic conductivity (meters per second) } \\
\hline & & & & & \multicolumn{4}{|c|}{ Slug tests } & \multirow[b]{3}{*}{ Aquifer test ${ }^{5}$} \\
\hline & & & \multicolumn{2}{|c|}{$\begin{array}{l}\text { Lithologic sample of } \\
\text { glaclal drift }\end{array}$} & \multicolumn{2}{|c|}{$\begin{array}{l}\text { Bouwer and Rice } \\
\text { Method }^{1}\end{array}$} & \multicolumn{2}{|c|}{$\begin{array}{l}\text { Cooper and others } \\
\text { Method }^{2}\end{array}$} & \\
\hline & & & $\begin{array}{l}\text { Permea- } \\
\text { meter }^{3}\end{array}$ & $\begin{array}{c}\text { Grain- } \\
\text { size } \\
\text { dry sieve }\end{array}$ & Forward & Reverse & Forward & Reverse & \\
\hline$\overline{\text { FS3-22 }}$ & $5.79-6.71$ & Till, Lodgement & -- & -- & -- & -- & ${ }^{6} 2.7^{-7}$ & -- & -. \\
\hline FS3-29 & $8.23-8.84$ & Till, Lodgement & -- & -- & -- & -- & $67.3^{-8}$ & - & -- \\
\hline FS3C-19 & $5.52-5.67$ & Till, Lodgement & -- & -- & $3^{-5}$ & $2.2^{-5}$ & $1.5^{-4}$ & $1.9^{-4}$ & $4.8^{-8}$ \\
\hline FS3C-24 & 7.24-7.39 & Till, Lodgement & -- & -- & $3.9^{-6}$ & $2.5^{-6}$ & $2.4^{-5}$ & $1.1^{-5}$ & -- \\
\hline FS3C-29 & $8.76-8.92$ & Till, Lodgement & - & -- & $1.1^{-6}$ & $9.2^{-7}$ & $1.6^{-6}$ & $1.1^{-6}$ & $4.8^{-8}$ \\
\hline FS3C & 1.52 & Sand and Gravel & -- & $1.2^{-4}$ & -- & -- & -- & -- & -- \\
\hline FS3C & 3.05 & Till, Lodgement & -- & $5.8^{-5}$ & -- & -- & -- & - & -- \\
\hline FS3C & $10.67-14.51$ & Bedrock & -- & -- & $4.0^{-9}$ & -- & $9.1^{-9}$ & -- & $4.8^{-7}$ \\
\hline WT-27 & $.31-2.13$ & Till, Lodgement & -- & -- & -- & -- & -- & -- & -- \\
\hline WT-27 & $.213-3.66$ & Till, Lodgement & -- & -- & -- & -- & -- & -- & -- \\
\hline WT-27 & $3.66-5.03$ & Till, Lodgement & -- & -- & -- & -- & -- & -- & -- \\
\hline WT-27 & $5.03-5.64$ & Till, Lodgement & $4.6^{-7}$ & -- & & -- & -- & -- & - \\
\hline WT-27 & $4.88-6.40$ & Till, Lodgement & -- & - & $4.0^{-7}$ & -- & $8.8^{-7}$ & - & - \\
\hline FS1-WT & $4.88-5.79$ & Till, Lodgement & -- & -- & -- & - & $67.0^{-7}$ & - & -- \\
\hline FS1-25 & $7.01-7.62$ & Till, Lodgement & -- & - & - & -- & $67.3^{-7}$ & $6.4^{-7}$ & -- \\
\hline FS1-35 & $10.07-10.67$ & Till, Ablation & -- & -- & -- & -- & $63.7^{-6}$ & $63.7^{-6}$ & -- \\
\hline B4 & $1.83-3.66$ & Sand and Gravel & -- & $2.5^{-5}$ & - & -- & -- & - & - \\
\hline B4 & $5.18-6.10$ & Till, Lodgement & $4.0^{-7}$ & - & -- & -- & -- & -- & -- \\
\hline$R 1-36$ & $1.83-3.05$ & Till, Ablation & - & -- & -- & -- & -- & -- & -- \\
\hline$R 1-36$ & $5.18-6.10$ & Till, Lodgement & -- & -- & - & - & - & -- & - \\
\hline$R 1-36$ & 6.71 & Till, Lodgement & -- & -- & -- & -- & -- & -- & - \\
\hline R1-36 & 10.06 & Till, Lodgement & -- & -- & - & -- & -- & - & -- \\
\hline TR1-63 & $17.37-19.20$ & -- & -- & - & -- & -- & ${ }^{6} 1.2^{-5}$ & ${ }^{6} 1.2^{-5}$ & - \\
\hline TR1-132 & $39.62-40.23$ & -- & -- & -- & -- & -- & ${ }^{6} 1.3^{-6}$ & ${ }^{6} 1.1^{-6}$ & -- \\
\hline $\begin{array}{l}\text { FS2 ter- } \\
\text { race }\end{array}$ & .61 & Sand and Gravel & - & $1.2^{-4}$ & -- & -- & -- & -- & - \\
\hline B3 & $1.83-3.05$ & Till, Lodgement & -- & $9.1^{-5}$ & -- & -- & - & -- & -- \\
\hline B3 & $3.05-4.57$ & Till, Lodgement & $4.0^{-5}$ & -- & -- & - & -- & -- & -- \\
\hline B3 & $4.57-6.10$ & Till, Lodgement & $3.0^{-6}$ & -- & -- & -- & -- & -- & -- \\
\hline
\end{tabular}


Table 2. Summary of hydraulic conductivity estimated from multiple techniques, Mirror Lake area, Grafton County, New Hampshire--Continued

$[-$, no data $]$

Hydraulic conductivity (meters per second)

\begin{tabular}{|c|c|c|c|c|c|c|c|c|c|}
\hline \multirow{3}{*}{$\begin{array}{c}\text { Weil/test } \\
\text { hole }\end{array}$} & \multirow{3}{*}{$\begin{array}{l}\text { Sampied } \\
\text { interval } \\
\text { (meters } \\
\text { beiow land } \\
\text { surface) }\end{array}$} & \multirow{3}{*}{$\begin{array}{c}\text { Hydro-geologic } \\
\text { unit }\end{array}$} & \multirow{2}{*}{\multicolumn{2}{|c|}{$\begin{array}{l}\text { Lithoiogic sampie of } \\
\text { glaciai drift }\end{array}$}} & \multicolumn{4}{|c|}{ Siug tests } & \\
\hline & & & & & \multicolumn{2}{|c|}{$\begin{array}{c}\text { Bouwer and Rice } \\
\text { Method }^{1}\end{array}$} & \multicolumn{2}{|c|}{$\begin{array}{l}\text { Cooper and others } \\
\text { Method }^{2}\end{array}$} & \\
\hline & & & $\begin{array}{l}\text { Permea- } \\
\text { meter }^{3}\end{array}$ & $\begin{array}{l}\text { Grain- } \\
\text { size } \\
\text { dry sieve }\end{array}$ & Forward & Reverse & Fonward & Reverse & Aquifer test ${ }^{5}$ \\
\hline
\end{tabular}

FSE6-WT 1.22-2.13 Sand and Gravel

FSE6-WT 3.35-4.27

FSE6-WT 3.20-4.72

FSE6-51 14.94-15.54 Till, Lodgement

FSE6-59 17.37-17.99 Till, Lodgement

$-$

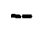

$-$

$-$

$-$

$\begin{array}{lllcr}\text { B2 } & 1.52-2.74 & \text { Sand and Gravel } & - & 9.8^{-5} \\ \text { B2 } & 3.35-3.96 & \text { Sand and Gravel } & - & 2.1^{-5} \\ \text { B2 } & 4.57-4.75 & \text { Till, Lodgement } & 4.6^{-9} & -- \\ \text { B2 } & 4.75-6.28 & \text { Till, Lodgement } & -- & - \\ \text { B2 } & 7.80-8.66 & \text { Till, Lodgement } & 1.0^{-10} & -\end{array}$

FSE1-32 9.15-9.75 Till, Lodgement

FSE1-43 12.50-13.11 Till, Lodgement

WT-11

$7.32-7.93$

WT-11 7.32-7.93

T1-8

$1.52-2.44$

CO1-WT 2.74-3.35 Till, Ablation

CO1-18 4.63-5.24 Till, Ablation

B1

$.85-2.38$

Till, Ablation

B1 $\quad 3.05$

Till, Ablation

CS-20R 5.18-10.52 Bedrock

$-$

$-$

$-$

$-$

-- -.

$\begin{array}{ccc}-- & 9.5^{-7} & 5.8^{-7}\end{array}$

$--\quad--$

$--\quad-$

$-$

$-$

$-$

$-$

$-$

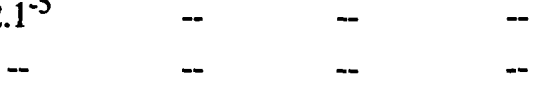

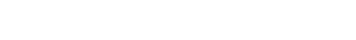

$-$

$-$

$68.5^{-7}$

$-$

$-$

$65.2^{-7}$

$\begin{array}{lll}- & 7.0^{-6} & 7.4^{-6}\end{array}$

$9.8^{-6}$

$62.1^{-5}$

$3.4^{-5}$

$-$

$--$

$3.4^{-6}$

$62.4^{-5}$

$-\quad 4.9^{-6}$

$3.3^{-7}$

$3.8^{-6}$

$2.1^{-6}$

${ }^{6} 1.2^{-5}$

$63.4^{-6}$

$3.6^{-6}$ (EARLY)

$5.0^{-6}$ (LATE)

\begin{tabular}{ccccccc}
-- & - & - & - & $62.1^{-5}$ & ${ }^{6} 1.8^{-5}$ & $6.6^{-6}$ (EARLY) \\
& & & & & & $8.3^{-6}$ (LATE) \\
- & $1.4^{-5}$ & - & - & - & - & - \\
- & $1.8^{-5}$ & - & -- & -- & -- & - \\
- & - & $8.5^{-7}$ & $3.0^{-6}$ & $3.0^{-6}$ & $2.3^{-6}$ & - \\
\hline
\end{tabular}

${ }^{1}$ Analyzed by methods described in Bouwer and Rice (1976).

${ }^{2}$ Analyzed by methods described in Cooper, Bredehoeft, and Papadopoulos (1967).

${ }^{3}$ Analyzed by methods described in Olsen (1985).

${ }^{4}$ Analyzed by methods described in Olney (1983).

${ }^{5}$ Analyzed by methods described in Neuman (1975).

${ }^{6}$ Wilson (1991). 
Table 3. Summary of porosity, speclific yield, and estimates of storage coefficlents. Mirror Lake area, Grafton County, New Hampshire

\begin{tabular}{|c|c|c|c|c|c|}
\hline $\begin{array}{l}\text { Test hole/ } \\
\text { well }\end{array}$ & $\begin{array}{c}\text { Intervai } \\
\text { (meters below } \\
\text { land surface) }\end{array}$ & $\begin{array}{c}\text { Hydrogeologic } \\
\text { unit }\end{array}$ & $\begin{array}{l}\text { Porosity } \\
\text { (percent) }^{1}\end{array}$ & $\begin{array}{l}\text { Speciflic } \\
\text { yieid }^{2}\end{array}$ & $\begin{array}{c}\text { Storage } \\
\text { coefficient }^{3}\end{array}$ \\
\hline FS3C-19 & $5.52-5.67$ & Till, brown & - & 0.03 & 0.0001 \\
\hline FS3C-29 & $8.76-8.92$ & Till, gray & -- & .03 & .003 \\
\hline FS3C & - & Bedrock & - & -- & .0008 to .001 \\
\hline \multirow[t]{2}{*}{ WT-27 } & $5.03-5.64$ & Till, gray & 25.8 & - & - \\
\hline & $5.55-7.16$ & Till, gray & 21.0 & - & -- \\
\hline B4 & $5.18-6.1$ & Till, brown, sandy & 30.7 & -- & - \\
\hline \multirow[t]{2}{*}{ B3 } & $3.05-4.57$ & Sand, kame terrace & 39.7 & - & - \\
\hline & $4.57-6.10$ & Till & 26.4 & -- & - \\
\hline \multirow[t]{2}{*}{ B2 } & $4.57-4.76$ & Till, brown & 21.0 & - & - \\
\hline & $7.8-9.66$ & Till, brown & 19.2 & -- & - \\
\hline WT-11 & $7.32-7.93$ & Till & $28-30$ & - & -- \\
\hline TR1-63 & $17.37-19.2$ & - & ${ }^{4} 12-14$ & - & -- \\
\hline B1 & $9.8-14.8$ & $\begin{array}{l}\text { Till, gray; sandy, abla- } \\
\text { tion }\end{array}$ & 30 & ${ }^{5} .09$ & -- \\
\hline CO1-WT & $2.74-3.35$ & Till, sandy, ablation & - & .01 & .0007 \\
\hline $\mathrm{CO} 1-18$ & $4.64-5.24$ & Till, sandy, ablation & - & .03 & .003 \\
\hline
\end{tabular}

${ }^{1}$ From permeameter test (Olsen, 1985).

${ }^{2}$ From aquifer-test analysis (Neuman, 1976).

${ }^{3}$ From aquifer-test analysis (Neuman, 1976).

${ }^{4}$ Neutron logging (Hodges, U.S. Geological Survey, written commun., 1992).

${ }^{5}$ Moisture retention curves (Hsieh, U.S. Geological Survey, written commun., 1991).

computations between dry and wet cores. Porosity estimates of glacial drift were also determined from borehole neutron logs (Richard Hodges, U.S.

Geological Survey, written commun., 1992) by use of methods described by Keyes and MacCary (1981, $\mathrm{p}$.

74). Specific-yield and storage-coefficient estimates were made by comparing early and late aquifer-test responses respectively, as described by Neuman (1975).

\section{Results}

Estimated hydraulic conductivities from wells and lithologic samples penetrating the glacial drift and shallow bedrock in the Mirror Lake area are given in table 2. Estimates of hydraulic conductivity from permeameter tests represent an average horizontal hydraulic conductivity from compaction rates ranging from 10 to $40 \mathrm{psi}$. Values of hydraulic conductivity from slug tests and aquifer tests represent the best match between theoretical and field data.
Summary of porosity, specific yield, and storagecoefficient estimates from permeameter tests, aquifer tests, borehole neutron logging, and soil-moistureretention tests is given in table 3 .

Plots of slug-test data, along with best-match type lines or curves generated by Bouwer and Rice (1976) and Cooper and others (1967), are shown in appendix C. A summary of parameters used in slug-test analyses is given in appendix D. Type curves from aquifer tests analyzed by Neuman (1975) method are shown in appendix E. A summary of parameters used in aquifer test analyses are given in appendix $F$.

A comparison of hydraulic-conductivity values from different techniques and methods used for two samples where this comparison is available is shown in figure 6. The results show agreement between values except for grain size at WT-27 because of the poor sorting characteristics of the lodgment till (see WT-27 curve in fig. 3). For deposits with better sorting, like the 
ablation till at CO1-18, estimates of hydraulic conductivity from grain size are similar to estimates of hydraulic conductivity of slug, permeameter, and aquifer-test methods. The comparison of hydraulicconductivity estimates indicates that grain-size analysis provides inaccurate estimates for the lodgment till. For this reason, estimates of hydraulic conductivity from grain sizes are restricted to the ablation till and stratified drift.

The similarity between hydraulic-conductivity values, albeit from a limited comparison, appears to indicate that heterogeneity of the glacial till is uniformly distributed at all test scales and that radial flow to wells is a good approximation of flow to wells screened in till at Mirror Lake. The similarity between hydraulic conductivities estimated at CO1-18 and WT27 from tests that integrate different sample volumes indicates that hydraulic conductivity is not affected by sample volume. This assessment agrees with the results of similar testing in unweathered Wisconsinan-age tills in Iowa (LaDon, 1993), but contrasts with results of an investigation of tills from other areas in the midwestern U.S. that show laboratory measurements of hydraulic conductivity are much lower than hydraulic conductivity from slug tests (Bradbury and Muldoon, 1990). In tills at Mirror Lake, the apparent absence of fractures seems to be an important factor in the scale independency of hydraulic conductivity.

\section{Glaclal Drift}

A comparison of hydraulic conductivities for four principal hydrogeologic units in glacial drift (stratified drift in kame terraces, ablation till, and weathered and slightly weathered lodgment tills) shows that the stratified drift in kame terraces and ablation till (meltout till) are more permeable than the two types of lodgment till (fig. 7). The most permeable lithologic samples are from the kame-terrace deposits. The least permeable samples are from lowermost units of the gray lodgemont till (FS3-29 and FSE-51).

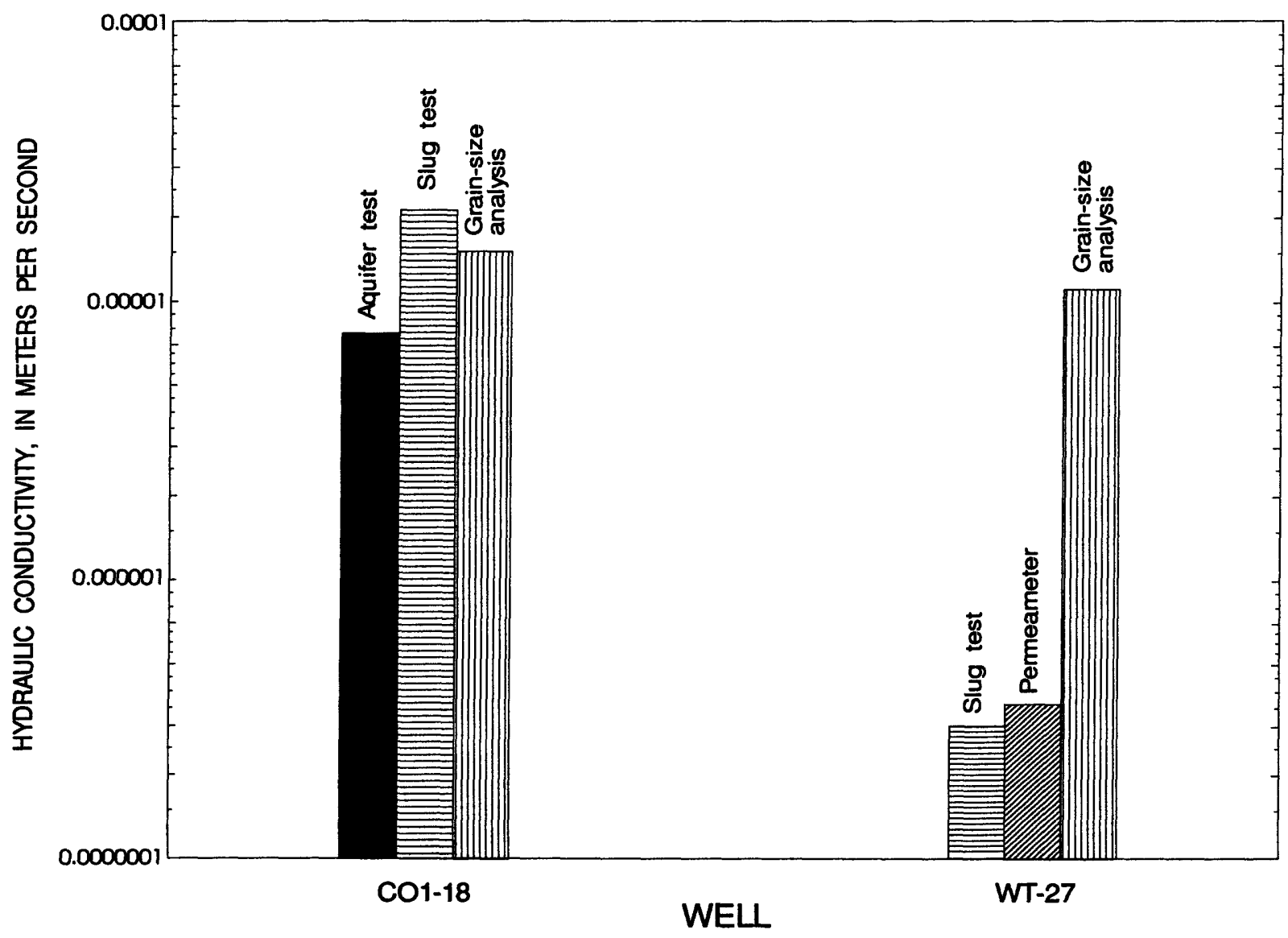

Figure 6. Comparlson of hydraulic conductlvity values estlmated from aquifer test, slug test, permeameter, and grain-size anaiysis for wells CO1-18 and WT-27 in the Mirror Lake area, New Hampshire. (Well locations shown in figure 2.) 


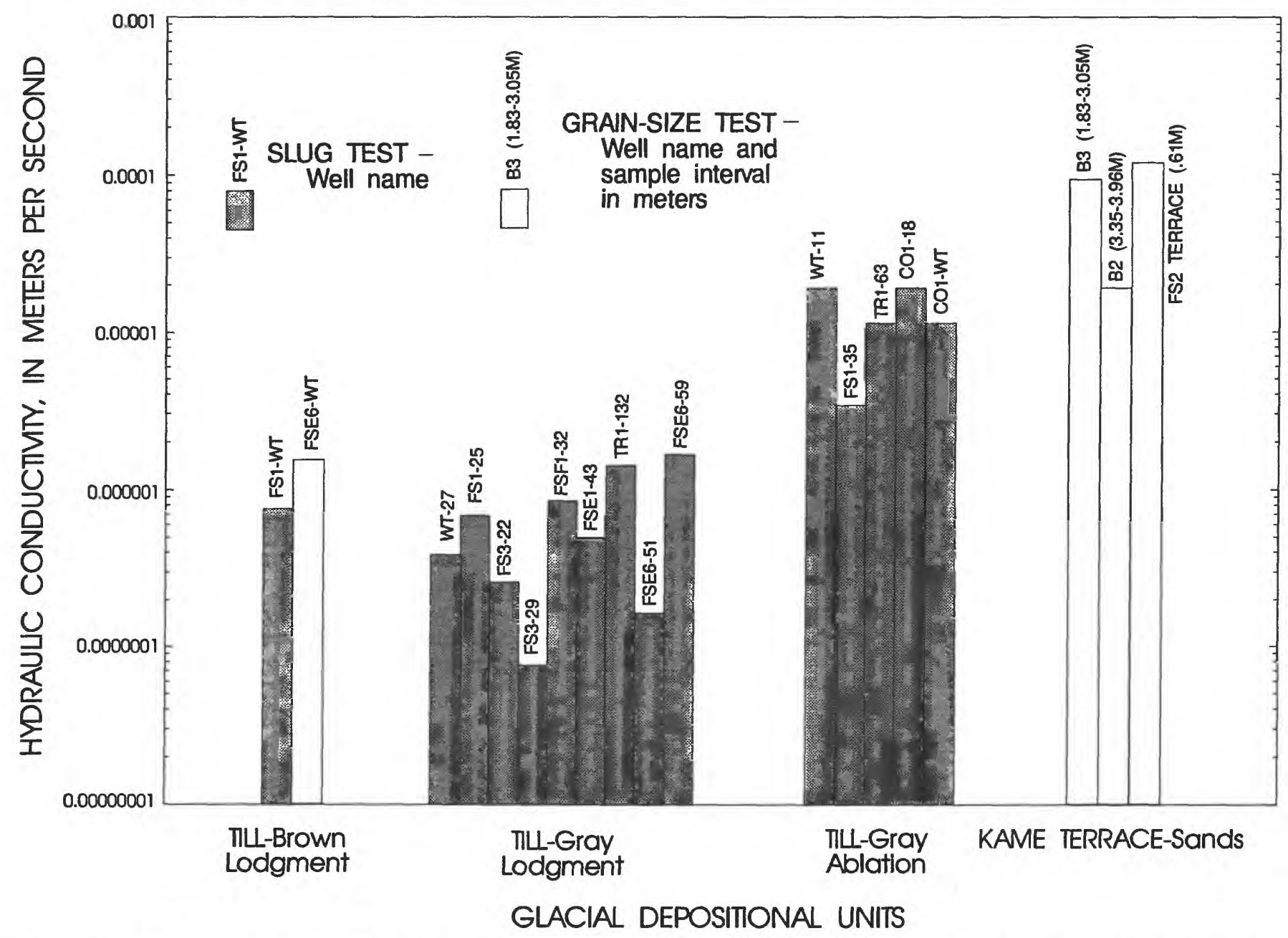

Figure 7. Estimates of hydraulic conductivity from glacial-drift hydrogeologic units in the Mirror Lake area, New Hampshire. (Well locations shown in figure 2.)

The distribution of the four hydrogeologic units in the Mirror Lake area control patterns of glacial- drift permeability. Lodgment till is predominant in the area upslope of Mirror Lake, whereas the ablation tills are found primarily at low altitudes. Thus, glacial drift has less permeability at high altitudes. This distribution in permeability also was reported by Wilson (1991, p. 16) for the Mirror Lake area.

Permeameter tests on six till cores showed similar hydraulic conductivities from different compaction rates ranging from 10 to $40 \mathrm{psi}$. All estimates of hydraulic conductivities from different compaction rates on some cores were within one-order of magnitude difference (H.W. Olsen, U.S. Geological Survey, written commun., 1990). This suggests that no secondary openings, such as fractures, were present. If fractures were present, and if they affected permeability, hydraulic conductivities under low rates of compaction would be greater than hydraulic conductivities under high rates of compaction.

Water levels from FS3C and CO aquifer tests are shown in figures 8 and 9 . The results from the tests show that withdrawals from the lowermost glacial-drift wells (FS3C-29 and CO1-18) affect water levels in other drift wells from the same cluster. Water levels at FS3C-29 stabilized when pumping rates decreased from 0.24 to $0.22 \mathrm{~L} / \mathrm{min}$ during the test. Water levels at CO1-18 did not stabilize and were continuing to decline after the pumping rate was decreased from $0.83 \mathrm{~L} / \mathrm{min}$ to 0.51 $\mathrm{L} / \mathrm{min}$. The deposits at well cluster $\mathrm{CO} 1$ have a higher hydraulic conductivity than deposits at well cluster FS3C (table 2) and can sustain greater rates of withdrawals because $\mathrm{CO} 1$ has more sand-size grains. 


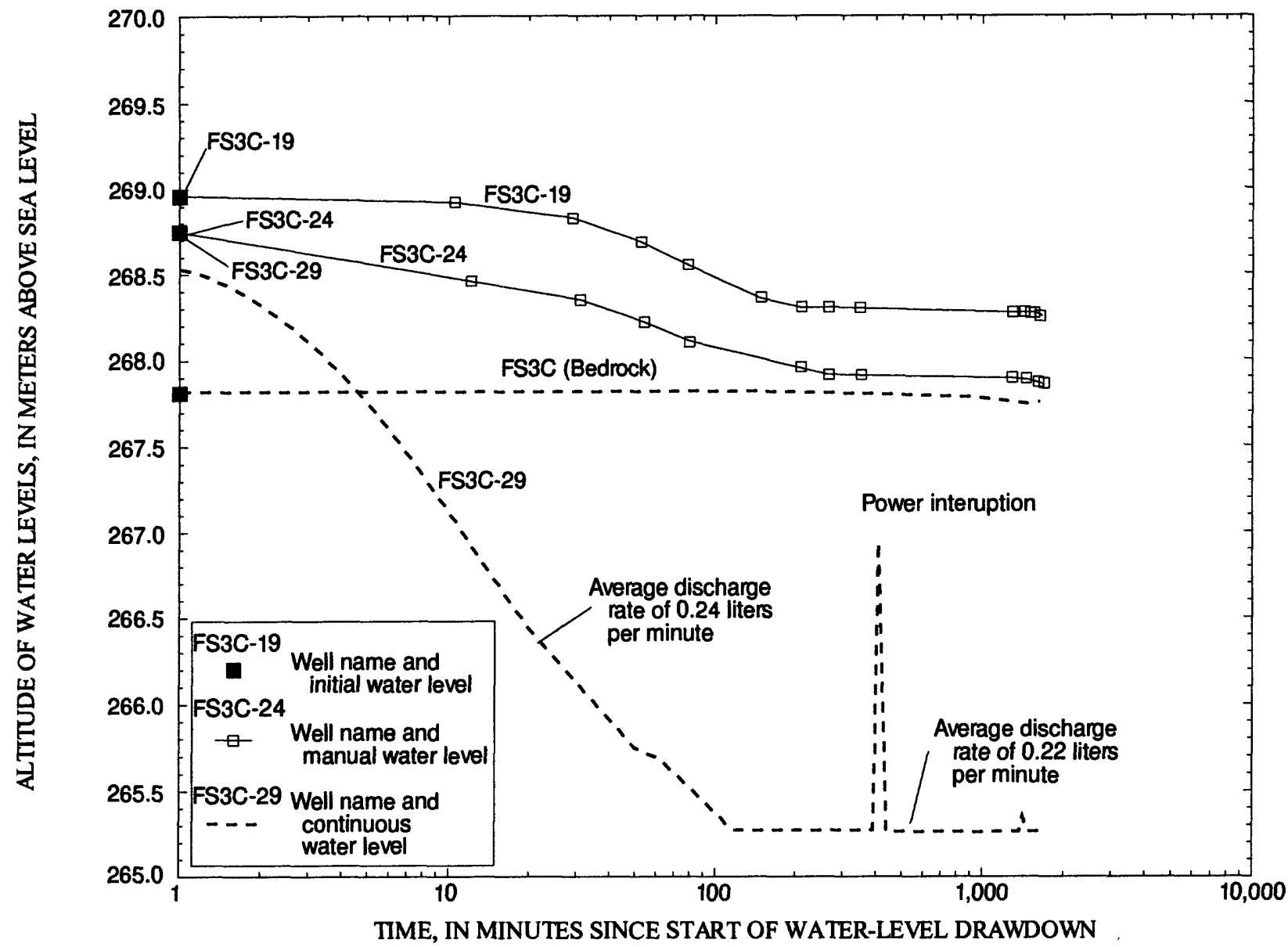

Figure 8. Water-level drawdowns from aquifer test for FS3C cluster wells, Mirror Lake, New Hampshire. (Weil locatlons shown in figure 2.)

Neuman-type curves for aquifer tests are sensitive to variations in transmissivity, storage coefficient, and the beta parameter that is a function of delayed gravity yield (Neuman, 1975). Neuman-type curves are not sensitive to variations in vertical anisotropy and specific yield because of the short duration of the aquifer test. For an improved estimate of the latter two parameters, longer duration tests are needed than those performed for this study. The best visual match of Neuman delayed-yield type curves with water-level drawdowns are provided in appendix $\mathrm{E}$.

Vertical anisotropy in the glacial drift was not observed in permeameter tests of cores and results from the aquifer tests. Horizontal and vertical estimates of hydraulic conductivity from permeameter tests of six till cores were similar. The apparent absence of vertical anisotropy in the till could be the result of poor sorting and the absence of stratified deposits.
Specific retention of water in glacial till is significant. The specific yield of the glacial till $(0.03)$ is almost an order of magnitude less than porosity estimates (table 3). Porosity of the till is as high as 30 percent, whereas estimates of specific yield typically range from 0.03 to 0.09 ( 3 to 9 percent). A specific yield of 0.03 to 0.09 is analogous to a silty clay to clayey sand or silt (fig. 10).

\section{Shailow Bedrock}

Hydraulic conductivities, as estimated by slug tests, are not affected by fracture frequency at shallow bedrock wells FS3C and CS-2OR. Estimated hydraulic conductivity was higher at CS-20R than at FS3C (table 1) but the latter contained more fractures. Many factors besides fracture frequency affect the hydraulic conductivity of the rock. Results of the analysis of the two shallow bedrock wells indicate that fracture 


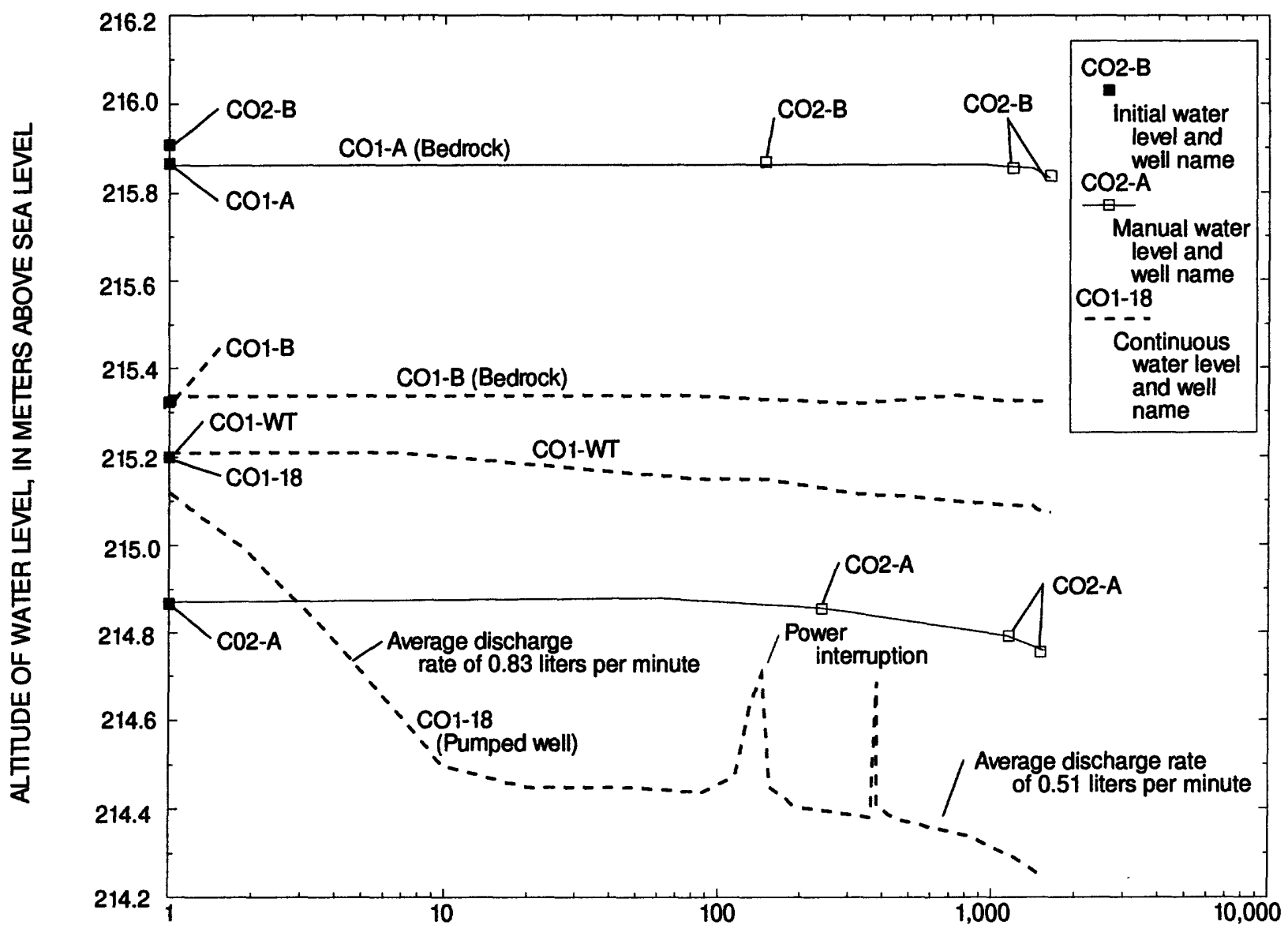

TIME, IN MINUTES SINCE START OF WATER-LEVEL DRAWDOWN

Figure 9. Water-level drawdowns from aquifer test for $\mathrm{CO}$ cluster wells, Mirror Lake area, New Hampshire. (Well locations shown in figure 2.)

frequency and aperture, the two factors that are used to determine hydraulic conductivity of rock from the Navier-Stokes equation (Snow, 1968), cannot account for the differences in hydraulic-conductivity estimates from the slug tests.

A comparison of estimated hydraulic conductivities from slug tests and computed hydraulic conductivities using Navier-Stokes equation and fracture characteristics at wells FS3C and CS-20R is shown in figure 11. Estimated hydraulic conductivities from slug tests, shown by vertical lines, is far less at FS3C than ranges of computed hydraulic conductivities shown by three horizontal bars for different fracture aperture and frequency ranges. Computed hydraulic conductivities for the 25th, 50th, and 75th percent fracture-aperture populations, and for fracture frequencies found in shallow bedrock, range from $4.0 \times 10^{-9}$ to $4.0 \times 10^{-6} \mathrm{~m} / \mathrm{s}$. The 25 th, 50 th, and 75 th percent fracture-aperture populations are sizes of fracture openings reported by Barton (1996) at the I-93 highway outcrop near CS-20R (fig. 2). A fracture aperture size at the 25 th percentile indicates that 25 percent of fractures are larger than that size and, conversely, 75 percent are smaller than that size. Therefore, the highest computed hydraulic conductivity of $4.0 \times 10^{-6} \mathrm{~m} / \mathrm{s}$ is produced from the largest specified aperture size of the 25 th percentile and highest specified fracture frequency of $8.2 \times 10^{-2}$ fractures per centimeter.

The difference between hydraulic conductivity values estimated from slug test and those computed from fracture characteristics at FS3C could be explained by the connectivity and infilling of fractures. Barton (1996) has shown that fracture connectivity within the Mirror Lake area is low. Fractures that do not connect to other fractures do not transmit water; therefore, FS3C may have more isolated fractures than CS-20R. Fractures filled with weathered materials or detritus (fracture infilling) can also decrease the water- 


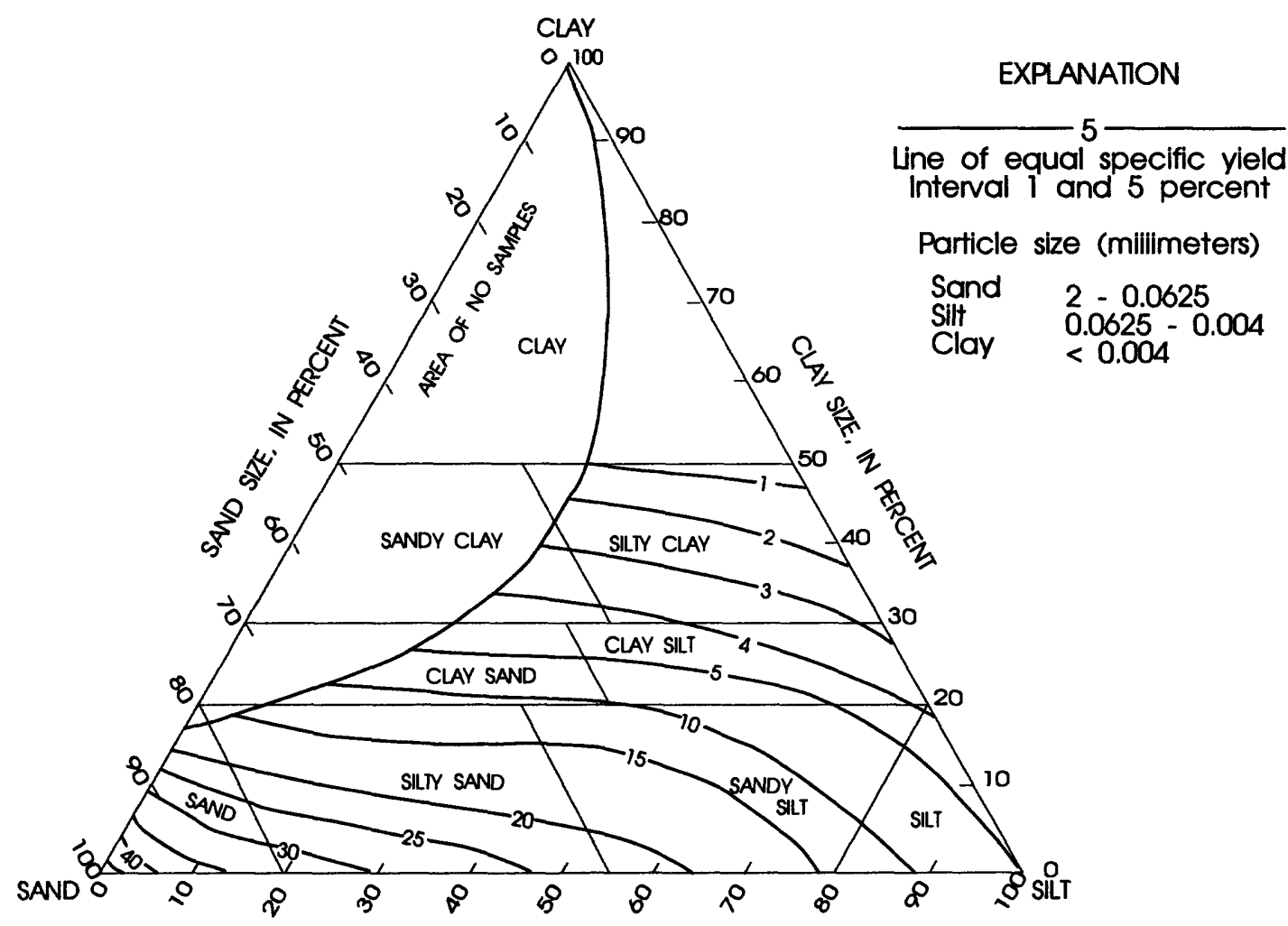

SILT SIZE, IN PERCENT

Figure 10. Textural classification relating grain size and specific yleld. (From Johnson, 1967)

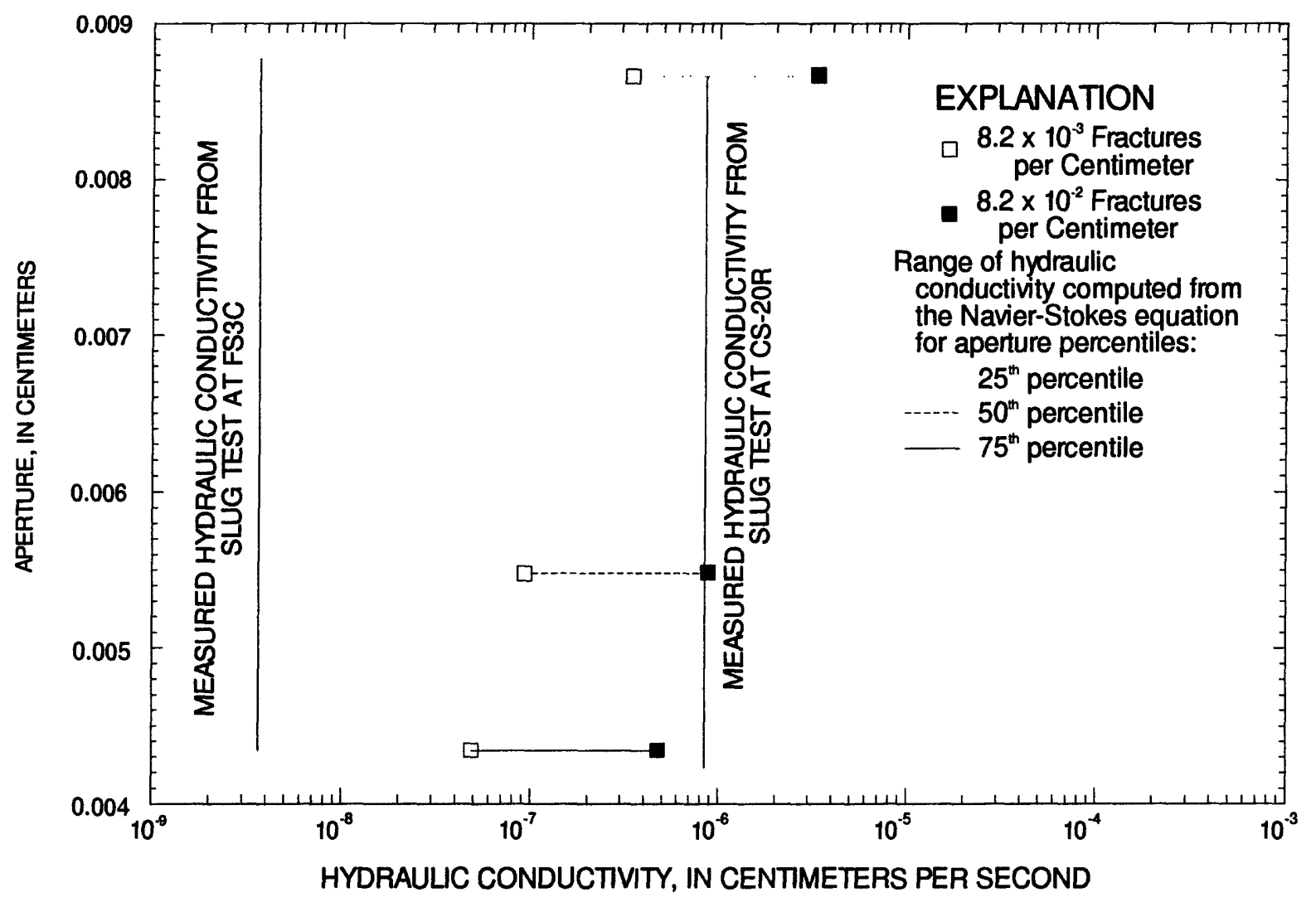

Figure 11. Estimates of hydraullic conductivity from shallow bedrock in the Mirror Lake area by use of the NavierStokes equation and slug tests. 
transmitting properties of a fracture. Examination of fracture surfaces from FS3C and CS-20R show that those from CS-20R are much cleaner than those from FS3C.

Hydraulic interconnection of deep glacial drift and shallow bedrock is indicated in two instances where bedrock water levels respond to low rates of withdrawal in the basal drift. Withdrawals at FS3C-29 cause drawdowns $23.5 \mathrm{~m}$ away at FS3C (fig. 8 and appendix E4). Withdrawals at CO1-18 cause drawdowns $15 \mathrm{~m}$ away at $\mathrm{CO} 2-\mathrm{A}$ but not at $\mathrm{CO} 1$-A (fig. 9), although CO1-18 is located less than $3 \mathrm{~m}$ from CO1-A. Borehole logs from CO2-A (F.L. Paillet, written commun., 1993) show sets of shallow fractures, whereas fractures are not found at shallow depths at CO1-A (Paillet and Kapucu, 1989). Aquifer test results show the importance of fracture distribution on ground-water flow in bedrock and hydraulic interconnection between deep glacial drift and shallow bedrock.

The estimates of hydraulic conductivity from the aquifer test at FS3C (table 2) are several orders of magnitude higher than the estimates from the slug test. Further work is needed to explain the difference; however, one possible explanation is scale-dependent heterogeneity which was not found in the till.

Results from the two aquifer tests indicate that vertical anisotropy at the bedrock surface is probably not important in controlling vertical flow during the tests performed. Type-curve comparisons for vertical anisotropy ratios of 1:100 and 1:1 (isotropic) to FS3C water-level drawdowns show only small differences (appendix E4).

\section{SUMMARY AND CONCLUSIONS}

Four types of glacial-drift hydrogeologic units were detected at nine test holes drilled for this study; a kame-terrace deposit, ablation till, and two types of lodgment till--a brown weathered till and a gray slightly less-weathered till. The hydraulic conductivity of the kame terrace, a stratified-drift deposit, is about $1.0^{-4} \mathrm{~m} / \mathrm{s}$. The hydraulic conductivity of the ablation till, a gray sandy till in the Mirror Lake area, is about $2.0^{-5} \mathrm{~m} / \mathrm{s}$. The hydraulic conductivity of the brown and gray lodgment till, a much more compact till than the ablation till, is about $5.0^{-7} \mathrm{~m} / \mathrm{s}$. Preliminary data show little difference in hydraulic conductivity of the brown and gray lodgment till.
Hydraulic conductivities of the till are similar when methods that integrate different sample volumes are used. These methods include permeameter tests on cores, slug tests, and aquifer tests. The similarity of estimates determined by these methods indicates that heterogeneity differences are not measured by the scale of the tests. This scale insensitivity implies that fractures in till were not detected. Vertical anisotropy also was not detected.

Coring of shallow bedrock at six test holes encountered no weathered bedrock or saprolite in the uppermost $5 \mathrm{~m}$ of bedrock. Rock types include two major classes, the host metamorphic rock (primarily schist) and a variety of igneous intrusives (primarily granite).

Fracture frequency of the shallow bedrock generally increased with altitude and estimates of hydraulic conductivity from slug tests at two shallow bedrock wells decreased with altitude. The less fractured bedrock (at low altitudes) was primarily schist with clean fracture surfaces, whereas the more fractured bedrock (at high altitudes) was primarily a leucocratic granite with fractures filled with particles and weathered fracture surfaces.

Drawdowns of bedrock water levels occurred for minor ground-water withdrawals in the lowermost glacial drift, which indicates that a relatively good hydraulic connection exists between the glacial drift and shallow bedrock. Results of two aquifer tests indicate no significant vertical anisotropy or reduction in horizontal hydraulic conductivity between the glacial drift and shallow bedrock.

\section{REFERENCES CITED}

Barton, C.C., 1996, Characterizing bedrock fractures in outcrop for studies of ground-water hydrology: An example from Mirror Lake, Grafton County, New Hampshire, in Morganwalp, D.W., ed., U.S. Geological Survey Toxics Substances Program: Proceedings of the technical meeting, Colorado Springs, Colo., September 1993: U.S. Geological Survey Water Resources Investigations Report 94-4015, vol.1, p. 81-88.

Bradbury, K.R., and Muldoon, M.A., 1990, Hydraulic conductivity determinations in unlithified glacial and fluvial materials, in Ground water and vadose zone monitoring, ASTM STP 1053, D.M. Nielson and A.L. Johnson, eds: Philadelphia, American Society for Testing and Materials, p. 138-151. 
Bouwer, Herman, and Rice, R.C., 1976, A slug test for determining hydraulic conductivity of unconfined aquifers with completely or partially penetrating wells: Water Resources Research, v. 12, no. 3, p. 423-428.

Cooper, H.H., Jr., Bredehoeft, J.D., and Papadopoulos, I.S., 1967, Response of a finite-diameter well to an instantaneous charge of water: Water Resources Research, v. 3, no. 1, p. 263-269.

Davis, S.N., and Turk, L.J., 1964, Optimum depth of wells in crystalline rocks: Ground Water, v. 2, p. 6-11.

Denny, C.S., 1982, Geomorphology of New England: U.S. Geological Survey Professional Paper 1208, 18 p.

Gale, J.E., 1982a, Assessing the permeability characteristics of fractured rock: in Narasimhan, T.N., ed., Recent trends in hydrogeology: Geological Society of America Special Paper 189, p. 163-181.

$1982 \mathrm{~b}$, The effects of fracture type (induced vs. natural) on the stress, fracture-closure, fracture-permeability relationships, in Goodman, R.E., and Heuze, F.E., eds., Proceedings of 23rd U.S. Rock Mechanics Symposium, Berkeley, Calif., August 25-27, 1982: New York, New York, Society of Mining Engineers of the American Institute of Mining, Metallurgical, and Petroleum Engineers, Inc., p. 290-298.

Geraghty and Miller, Inc., 1991, AQTESOLV users manual: Reston, Vir., 135 p.

Goldthwait, J.W., and Kruger, F.C., 1938, Weathered rock in and under the drift in New Hampshire: Bulletin of the Geological Society of America, v. 49, p. 1183-1198.

Harte, P.T., 1992, Regional ground-water flow in crystalline bedrock and interaction with glacial drift in the New England Uplands: University of New Hampshire, Durham, N.H., published masters thesis, $147 \mathrm{p}$.

Harte, P.T., and Winter, T.C., 1995, Simulations of flow in fractured crystalline rock in a hypothetical New England Setting: Ground Water, v. 33, no 3, p. 953-964.

Harte, P.T., and Winter, T.C., 1996, Factors affecting recharge to crystalline rock in the Mirror Lake area, Grafton County, New Hampshire, in Morganwalp, D.W., and Aronson, D.A., eds., U.S. Geological Survey Toxics Substances Hydrology Program: Proceedings of the technical meeting, Colorado Springs, Colo., September 20-24, 1993: U.S. Geological Survey Water-Resources Investigations Report 94-4015, vol. 1, p. 141-150.

Hsieh, P.A., Shapiro, A.M., Barton, C.C., Haeni, F.P., Johnson, C.D., Martin, C.W., Paillet, F.L., Winter, T.C., Wright, D.L., 1993, Methods of characterizing fluid movement and chemical transport in fractured rock, in
Chaney, J.T., and Hepburn, J.C., eds.: Field Trip Guidebook for northeastern United States, Geological Society of America, Annual Meeting, October 25-28, 1993, Boston, Mass., v. 2, chap. R, p. R1-R3.

Johnson, A.I., 1967, Specific yield--Compilation of specific yields for various materials: U.S. Geological Survey Water-Supply Paper 1662-D, 74 p.

Keeler, C.K., Van Der Kamp, G., and Cherry, J.A., 1988, Hydrogeology of two Sasketchewan tills, 1) Fractures, bulk permeability, and spatial variability of downward flow: Journal of Hydrology, v. 101, p. 97-121.

1989, A multiscale study of the permeability of a thick clayey till: Water Resources Research, v. 25 , no. $11, \mathrm{p}$. 2299-2317.

Keyes, W.S., and MacCary, L.M., 1981, Application of borehole geophysics to water-resources investigations: U.S. Geological Survey Techniques of Water-Resources Investigations, chap. E1, book 2, p. 126.

Knopman, D.S., and Hollyday, E.F., 1993, Variation in specific capacity in fractured rocks, Pennsylvania: Ground Water, v. 31 , no. 1 , p. 135-145.

Koteff, Carl, and Pessl, Fred, Jr., 1985, Till stratigraphy in New Hampshire: Correlations with adjacent New England and Quebec, in Borns, H.W., LaSalle, Pierre, and Thompson, W.B., eds., Late Pleistocene history of northeastern New England and adjacent Quebec: Geological Society of America Special Paper 197, p. 1-12.

LaDon, Jones, 1993, A comparison of pumping and slug tests for estimating the hydraulic conductivity of unweathered Wisconsian age till in Iowa: Ground Water, v. 31, no. 6, p. 896-904.

LeGrand, H.E., 1967, Ground water of the piedmont and blue ridge provinces in the southeastern states: U.S. Geological Survey Water-Resources Circular no. 538, 11 p.

Lyons, J.B., Bothner, W.A., Moench, R.H., and Thompson, J.B., Jr., eds., 1986, Interim geologic map of New Hampshire: Concord, N.H., New Hampshire Department of Resources and Economic Development, OpenFile Report 86-1, 1 sheet, scale 1:250,000.

Melvin, R.L., de Lima, Virginia, Stone, B.D., 1992, The stratigraphy and hydraulic properties of tills in southern New England: U.S. Geological Survey Open-File Report 91-481, $53 \mathrm{p}$. 
Moore, R.B., Johnson, C.D., Douglas, E.M., 1994, Geohydrology and water quality of stratified-drift aquifers in the Lower Connecticut River Basin, Southwestern New Hampshire: U.S. Geological Survey Water-Resources Investigations Report 92-4013, 68 p., 4 pls.

Neuman. S.P., 1975, Analysis of pumping test data from anisotropic unconfined aquifers considering delayed gravity response: Water Resources Research, v. 11, no. 2, p. 329-342.

Olney, S.L., 1983, An investigation of the relationship between the coefficient of permeability and effective grain size of unconsolidated sands: Boston University, Boston Mass., unpublished Master's thesis, 61 p.

Olsen, H.W., Nichols, R.W., and Rice, T.L., 1985, Low gradient permeability measurements in a triaxial system: Geotechnique, v. 35 , no. 2, p. 145-157.

Paillet, F.L., and Kapucu, Kemal, 1989, Fracture characterization and fracture-permeability estimates from geophysical logs in the Mirror Lake watershed, New Hampshire: U.S. Geological Survey Water-Resources Investigations Report 89-4058, 49 p.

Randall, A.D., Francis, R.M., Frimpter, M.H., Emery, J.M., 1988, Region 19, Northeastern Appalachians, in Back, William, Rosenshein. J.S., and Seaber, P.R., eds., Hydrogeology: Boulder, Colo., Geological Society of America, The Geology of North America, v. 0-2, p. 177 187.

Rowe, R.K., and Booker, J.R., 1990, Contaminant migration through fractured till into an underlying aquifer: Canadian Geotechnical Journal, v. 27, p. 484-495.

Shapiro, A.M., and Hsieh, P.A., 1991, Research in fractured rock hydrogeology: Characterizing fluid movement and chemical transport in fractured rock at the Mirror Lake drainage basin, New Hampshire, in Mallard, G.E., and Aronson, D.A., eds. Toxic Substances Hydrology Program Proceedings of Technical Meeting, Monterey, Calif., March 11-15, 1991: U.S. Geological Survey Water Resources Investigations Report 91-4034, p. 155161.

Sever, C.W., 1964, Geology and ground-water resources of crystalline rocks, Dawson County, Georgia: U.S. Geological Survey Information Circular, no. 30, 5 p.

Snow, D.T., 1968, Rock fracture spacings, openings, and porosities: Journal of the Soil Mechanics and Foundations Division, Proceedings of the American Society of Civil Engineers, v. 94 (SMI), p. 73-91.
Stewart, Glenn, 1967, Drilled water wells in New Hampshire: Concord, N.H., New Hampshire Department of Resources and Economic Development, Mineral Resources Survey, Part XX, 58 p.

Strobel, M.L., 1993, Hydraulic properties of three types of glacial deposits in Ohio: U.S. Geological Survey Water Resources Investigations Report 92-4135, 41 p.

Theim, G., 1906, Hydrologische Methoden: Gebhardt, Leipzig, $56 \mathrm{p}$.

Trainer, F.W., 1988, Hydrogeology of the plutonic and metamorphic rocks, in Back, William, Rosehshein, J.S., and Seaber, P.R., eds., Hydrogeology: Boulder, Colo., Geological Society of America, The Geology of North America, v. O-2, p. 367-380.

Wilson, Alicia, 1991, Distribution of hydraulic conductivity in the glacial drift at Hubbard Brook Experimental Forest, West Thornton, New Hampshire: Dartmouth College, Hanover, N.H., unpublished Senior's Honors thesis, $56 \mathrm{p}$.

Winter, T.C., 1984, Geohydrologic setting of Mirror Lake, West Thornton, New Hampshire: U.S. Geological Survey Water-Resources Investigations Report 84-4266, $61 \mathrm{p}$.

1985, Mirror Lake and its watershed, A. Physiographic setting and geologic origin of Mirror Lake, in Likens, G.E., ed., An ecosystem approach to aquatic ecology: Mirror Lake and its environment: New York, SpringerVerlag, p. 40-53.

Wyrick, and Borchers, 1981, Hydrologic effects of stressrelief fracturing in an Appalachian Valley: U.S. Geological Survey Water-Supply Paper 2177.

Wood, W.W., Shapiro, A.M., Hsieh P.A., Councell, Terry, in press, Observational experimental and inferred evidence for solute diffusion in fractured granite aquifers: Examples from the Mirror Lake Watershed, Grafton County, New Hampshire, in Morganwalp, D.W., and Aronson, D.A., eds., U.S. Geological Survey Toxic Substances Hydrology Program--Proceedings of the technical meeting, Colorado Springs, Colo., September 20-24. 1993: U.S. Geological Survey Water-Resources Investigations Report 94-4014. 


\section{APPENDIX A}


Table A-1. Selected test hole and well data from the Mirror Lake area, Grafton County, New Hampshire [--, no data]

\begin{tabular}{|c|c|c|c|c|c|c|}
\hline $\begin{array}{c}\text { Test hole/ } \\
\text { well } \\
\text { (fig. 2) }\end{array}$ & $\begin{array}{c}\text { Altitude of } \\
\text { measurement } \\
\text { point } \\
\text { (meters above } \\
\text { sea level) }\end{array}$ & $\begin{array}{l}\text { Altitude of } \\
\text { land surface } \\
\text { (meters } \\
\text { above sea } \\
\text { level) }\end{array}$ & $\begin{array}{l}\text { Depth of } \\
\text { hole } \\
\text { (meters } \\
\text { below land } \\
\text { surface) }\end{array}$ & $\begin{array}{l}\text { Depth to } \\
\text { bedrock } \\
\text { (meters } \\
\text { below land } \\
\text { surface) }\end{array}$ & $\begin{array}{l}\text { Depth to top of } \\
\text { well opening } \\
\text { (meters below } \\
\text { land surface) }\end{array}$ & $\begin{array}{c}\text { Depth to } \\
\text { bottom of well } \\
\text { opening } \\
\text { (meters below } \\
\text { land surface) }\end{array}$ \\
\hline FS3-11(WT) & 275.04 & 274.00 & 3.35 & - & 2.74 & 3.35 \\
\hline FS3-22 & 275.05 & 274.00 & 7.01 & - & 5.79 & 6.71 \\
\hline FS3-29 & 275.02 & 274.04 & 8.84 & - & 8.23 & 8.84 \\
\hline FS3 & 274.45 & 273.84 & 225.54 & 8.84 & 12.04 & 170.74 \\
\hline FS3C-14 & 273.81 & 273.41 & 4.33 & - & 3.95 & 4.1 \\
\hline FS3C-19 & 274.27 & 273.65 & 5.91 & -- & 5.52 & 5.67 \\
\hline FS3C-24 & 274.32 & 273.7 & 7.62 & -- & 7.24 & 7.39 \\
\hline FS3C-29 & 274.13 & 273.7 & 9.14 & - & 8.76 & 8.92 \\
\hline FS3C & 274.66 & 273.62 & 14.51 & 9.76 & 10.67 & 14.51 \\
\hline WT-27 & 266.93 & 265.85 & 9.91 & - & 4.88 & 6.4 \\
\hline FS1-17(WT) & 262.64 & 261.3 & 6.10 & -- & 4.88 & 5.79 \\
\hline FS1-25 & 262.35 & 261.15 & 7.62 & -- & 7.01 & 7.62 \\
\hline FS1-35 & 262.22 & 260.69 & 10.67 & -- & 10.06 & 10.67 \\
\hline FS1 & 261.88 & 261.27 & 137.15 & 14.02 & 16.46 & 137.15 \\
\hline B4 & - & 261.3 & 15.79 & 12.65 & -- & - \\
\hline R1-36 & 257.30 & 256.46 & 11.13 & -- & 9.6 & 11.13 \\
\hline R1-55 & 257.32 & 256.24 & 16.15 & -- & 15.54 & 16.15 \\
\hline R1 & 256.69 & 255.91 & 193.54 & 16.92 & 20.42 & 193.54 \\
\hline FS2-22 & 255.88 & 254.87 & 6.71 & -- & 6.1 & 6.71 \\
\hline FS2 & 255.76 & 255.04 & 152.39 & 7.38 & 9.75 & 152.39 \\
\hline WT-26 & 258.05 & 256.82 & 6.10 & - & 4.88 & 5.49 \\
\hline B3 & - & 256.12 & 11.59 & 8.84 & - & - \\
\hline TR1-63(WT) & 249.30 & 248.38 & 19.2 & -- & 17.37 & 19.2 \\
\hline TR1-132 & 249.42 & 248.5 & 40.23 & -- & 39.62 & 40.23 \\
\hline TR1 & 249.29 & 248.56 & 190.49 & 51.63 & 53.19 & 190.49 \\
\hline FSE6-41 & 243.04 & 242.18 & 12.5 & - & 11.89 & 12.5 \\
\hline B2 & - & 243.92 & 18.75 & 18.14 & - & - \\
\hline FSE6-16(WT) & 243.07 & 242.15 & 4.88 & - & 3.2 & 4.72 \\
\hline FSE6-51 & 243.08 & 242.09 & 15.54 & $-\cdots$ & 14.94 & 15.54 \\
\hline FSE6-59 & 243.11 & 242.27 & 17.98 & - & 17.37 & 17.98 \\
\hline FSE6 & 242.88 & 242.21 & 76.20 & 20.18 & 22.55 & 76.20 \\
\hline FSE-15(WT) & 241.98 & 240.18 & 4.57 & - & 3.05 & 4.57 \\
\hline FSE-23 & 241.06 & 240.03 & 7.01 & - & 6.4 & 7.01 \\
\hline FSE-32 & 241.03 & 239.82 & 9.75 & - & 9.14 & 9.75 \\
\hline FSE-43 & 241.02 & 239.66 & 13.11 & - & 12.50 & 13.11 \\
\hline
\end{tabular}


Table A-1. Selected test hole and well data from the Miror Lake area, Grafton County, New Hampshire-Continued

\begin{tabular}{lcccccc}
\hline $\begin{array}{c}\text { Test hole/ } \\
\text { well } \\
\text { (fig. 2) }\end{array}$ & $\begin{array}{c}\text { Altitude of } \\
\text { measurement } \\
\text { point } \\
\text { (meters above } \\
\text { sea level) }\end{array}$ & $\begin{array}{c}\text { Altitude of } \\
\text { land surface } \\
\text { (meters } \\
\text { above sea } \\
\text { level) }\end{array}$ & $\begin{array}{c}\text { Depth of } \\
\text { hole } \\
\text { (meters } \\
\text { below land } \\
\text { surface) }\end{array}$ & $\begin{array}{c}\text { Depth to } \\
\text { bedrock } \\
\text { (meters } \\
\text { below land } \\
\text { surface) }\end{array}$ & $\begin{array}{c}\text { Depth to top of } \\
\text { well opening } \\
\text { (meters below } \\
\text { land surface) }\end{array}$ & $\begin{array}{c}\text { Depth to } \\
\text { bottom of well } \\
\text { opening } \\
\text { (meters below } \\
\text { land surface) }\end{array}$ \\
\hline FSE1 & 240.20 & 239.83 & 108.2 & 13.75 & 16.15 & 108.2 \\
FSE2 & 241.06 & 240.3 & 107.99 & 15.15 & 17.07 & 107.99 \\
FSE3 & 241.01 & 240.31 & 108.2 & 15.64 & 18.59 & 108.2 \\
FSE4 & 241.26 & 240.71 & 229.5 & 14.87 & 18.29 & 229.5 \\
FSE5 & 242.36 & 241.65 & 61.26 & 13.20 & 16.92 & 61.26 \\
WT-11 & 240.98 & 240.06 & 7.93 & -- & 7.32 & 7.93 \\
T1-8 & 229.62 & 228.87 & 2.44 & - & 1.52 & 2.44 \\
& & & & & & \\
T1 & 229.08 & 228.47 & 152.4 & 3.66 & 6.10 & 152.4 \\
CO1-11(WT) & 218.00 & 217.20 & 3.35 & - & 2.74 & 3.35 \\
CO1-18 & 217.89 & 217.0 & 5.24 & - & 4.64 & 5.24 \\
CO1 & 217.70 & 217.14 & 175.86 & 5.79 & 9.14 & 175.86 \\
CO2 & 216.88 & 216.23 & 61.87 & 4.88 & 7.62 & 61.87 \\
& & & & & & - \\
B1 & 217.67 & 217.67 & 6.49 & 4.6 & - & - \\
CS-20R & 225.37 & 224.28 & 10.52 & 2.74 & 10.52 & 5.18 \\
IS1-WT & 225.21 & 224.44 & 5.79 & - & 4.94 & 5.61 \\
IS1-38 & 225.27 & 224.44 & 12.50 & - & 10.95 & 11.62 \\
IS1 & 224.68 & 224.13 & 152.39 & 12.74 & 17.07 & 152.39 \\
\hline
\end{tabular}




\section{APPENDIX B}

Lithologic logs fracture locations, natural gamma logs, and screened intervals for:

B1. (A) Test boring B1 and well site CO1, (B) test boring B3 and well site 26.

32

B2. (A) Well clusters FSE6 and FSE, and test boring B2, and (B) FS1 and test boring B4............... 33

B3. (A) Well WT-27, and (B) well site IS1, and (C) well site R1 ..................................................... 34

B4. (A) FS3C wells, and (B) well CS-20R .................................................................................... 35 
(A)

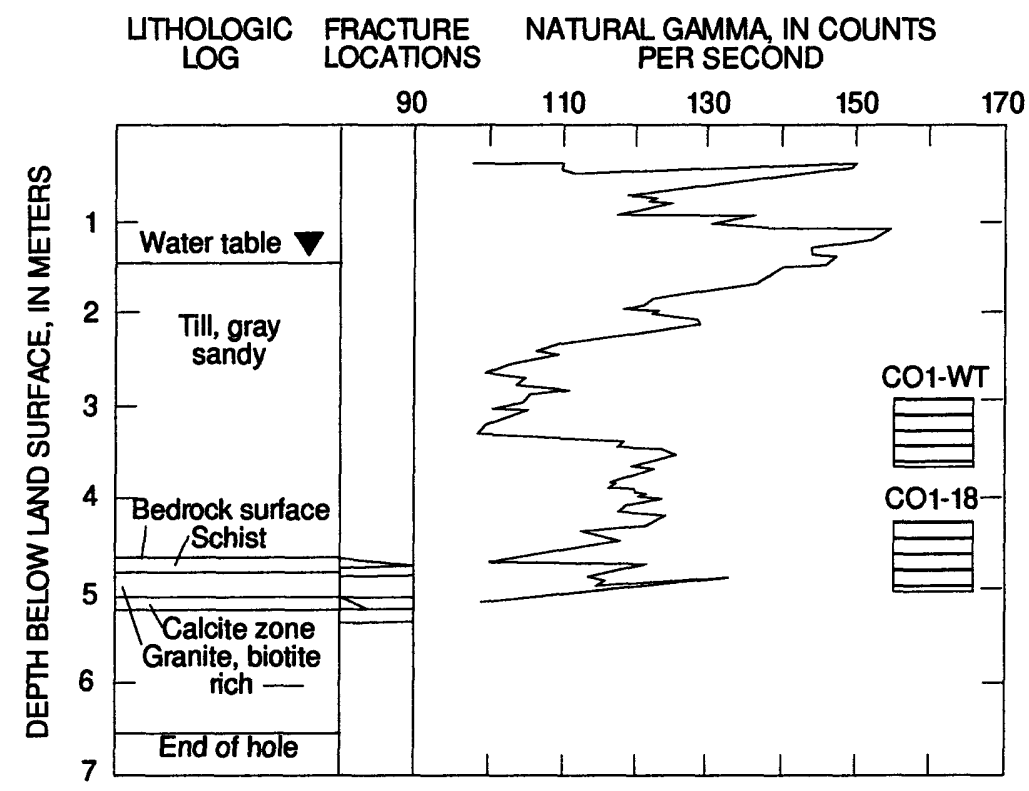

(B)

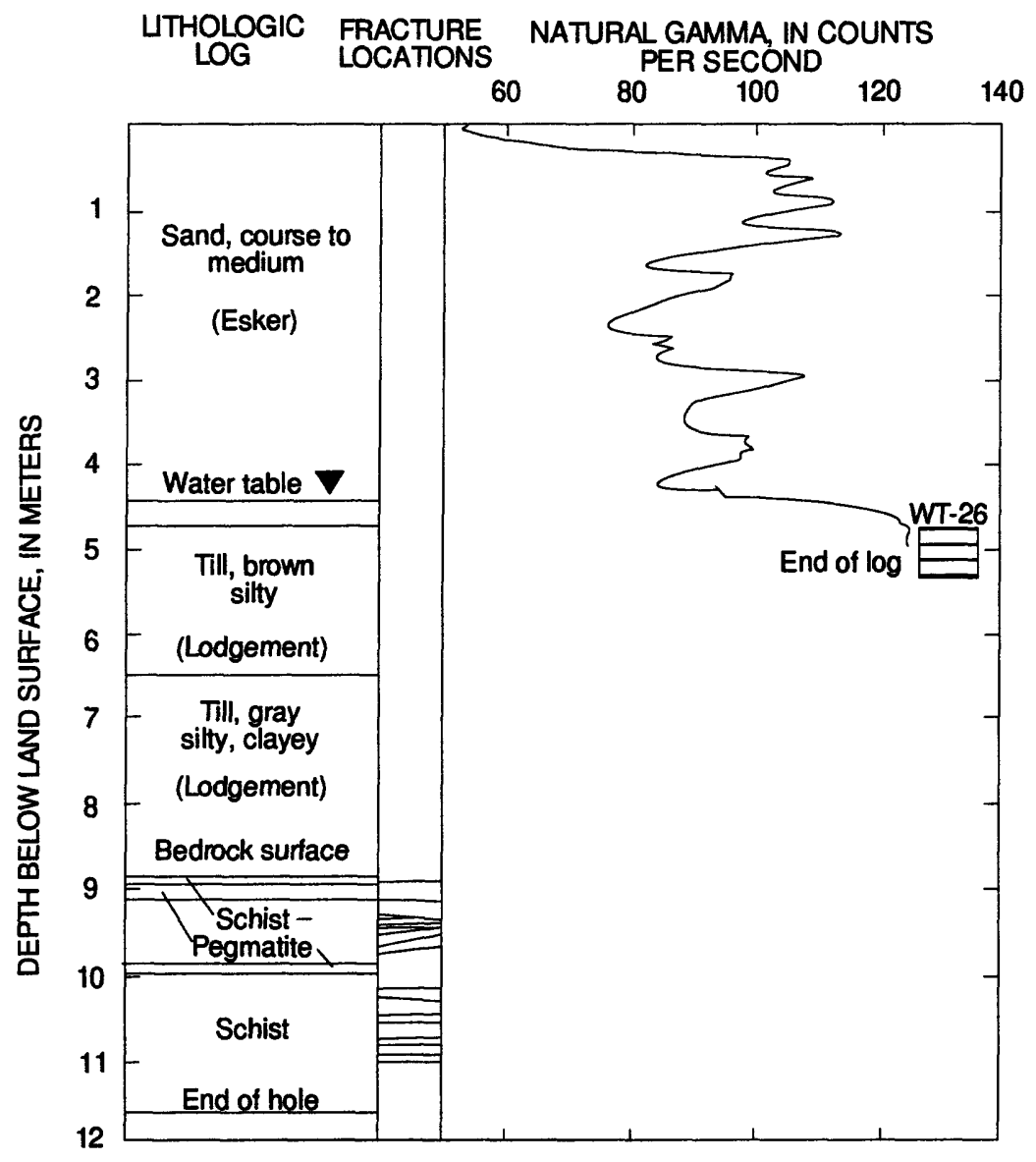

Appendix B1. Lithologic logs, fracture locations, natural gamma log, and screened intervals for (A) test boring B1 and well site CO1, and (B) test boring B3 and well site 26. 


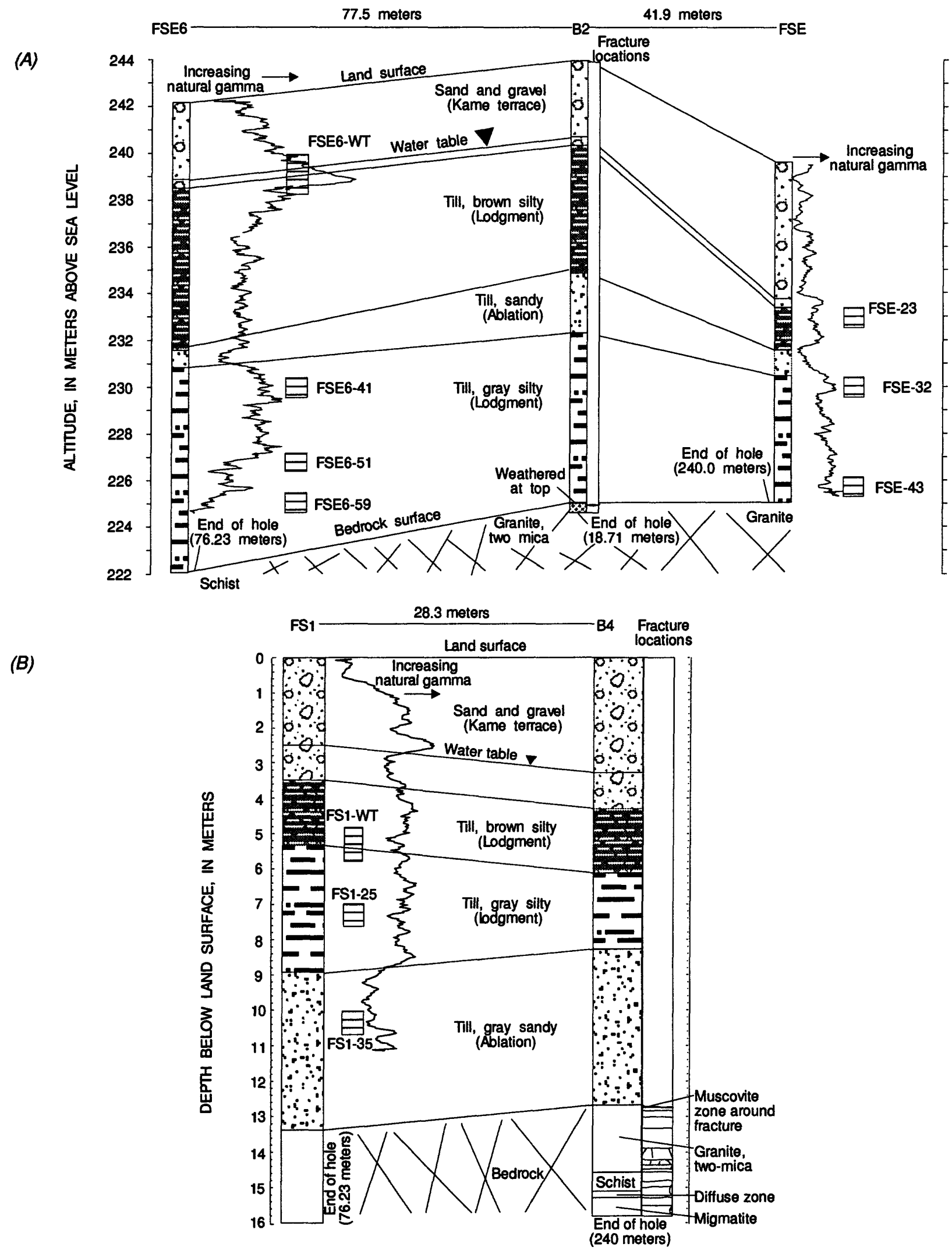

Appendix B2. Lithologic logs, fracture locations, natural gamma log, and screened intervals for (A) well clusters FSE6, FSE and test boring B2, and (B) FS1 and test boring B4. 


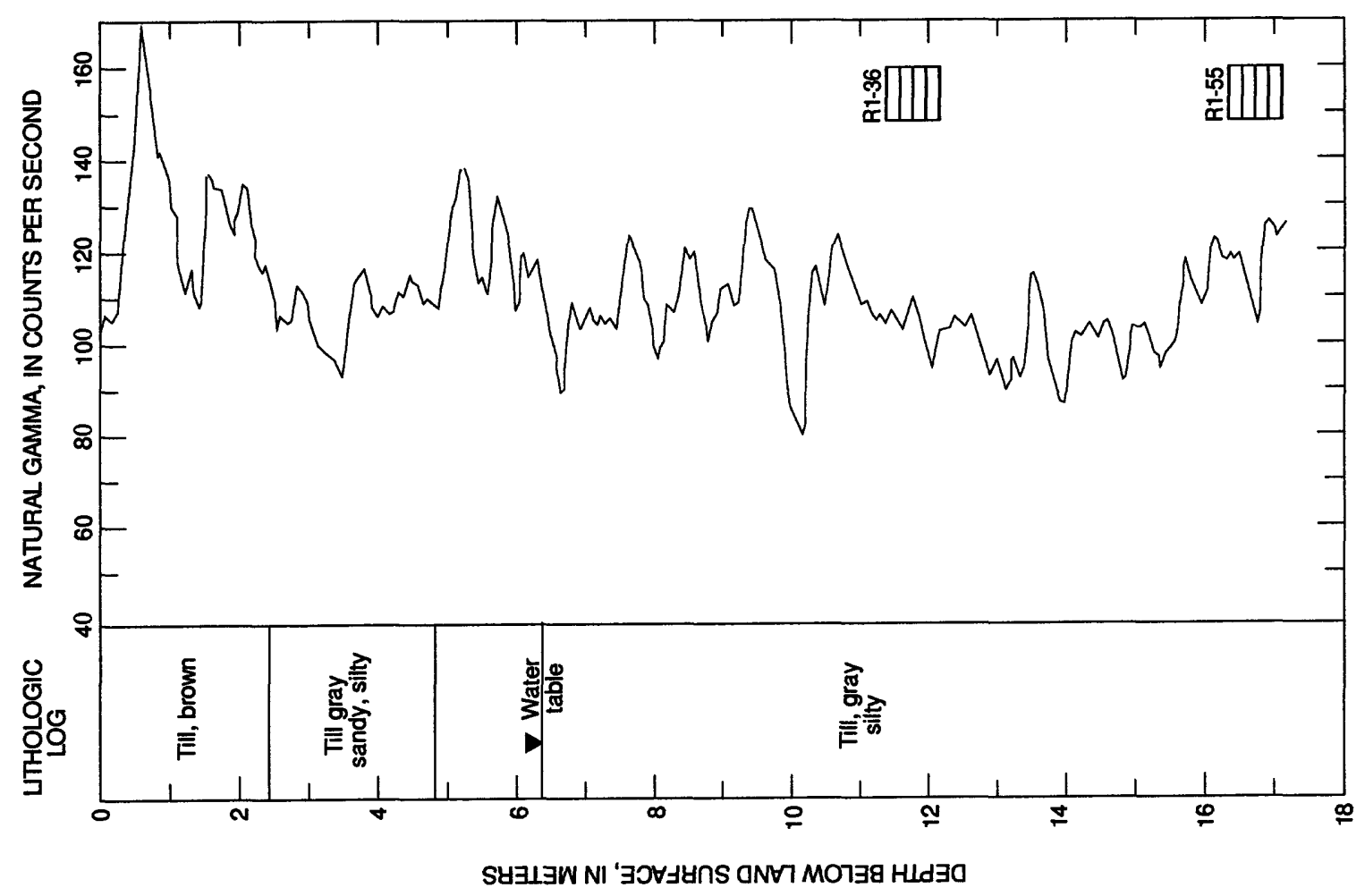

ֻิ

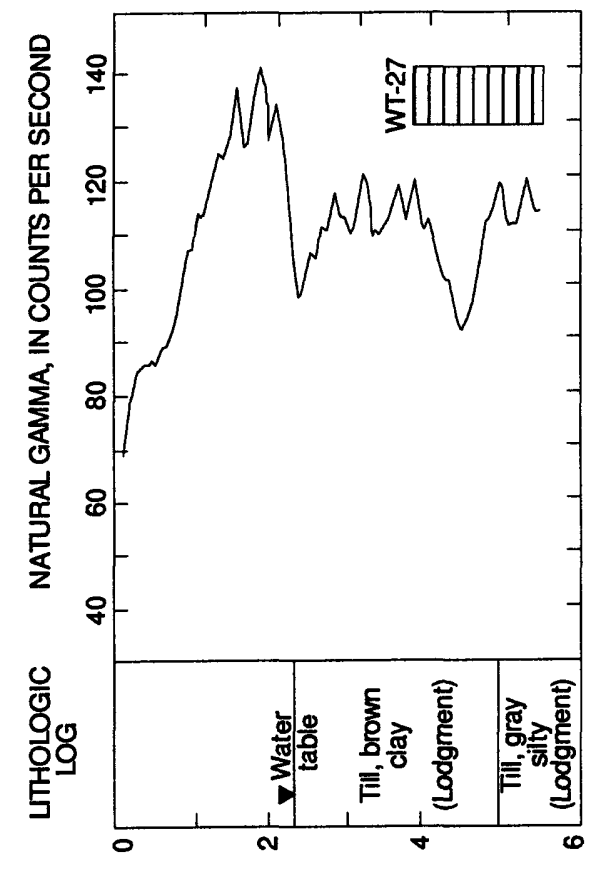

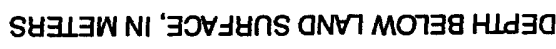

$\widehat{\leqslant}$

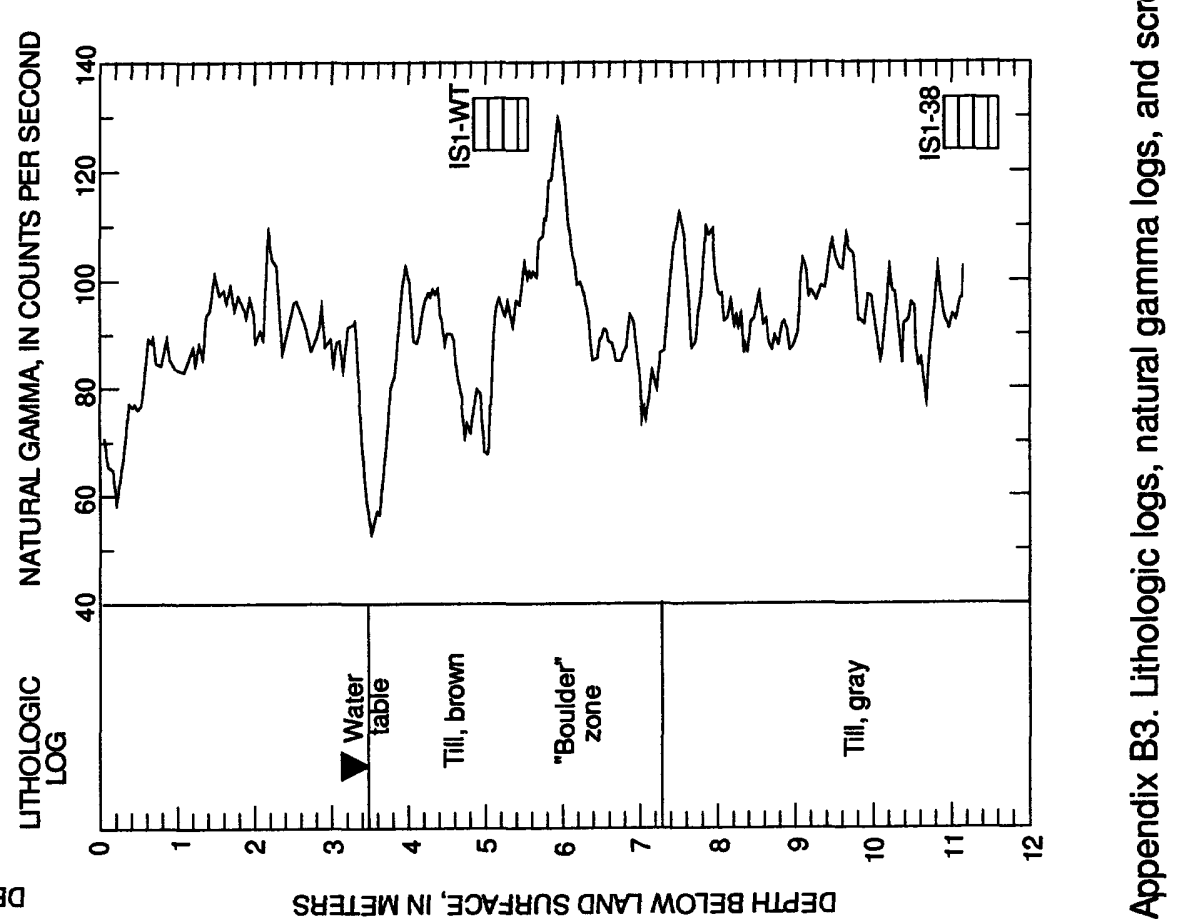

(0) 


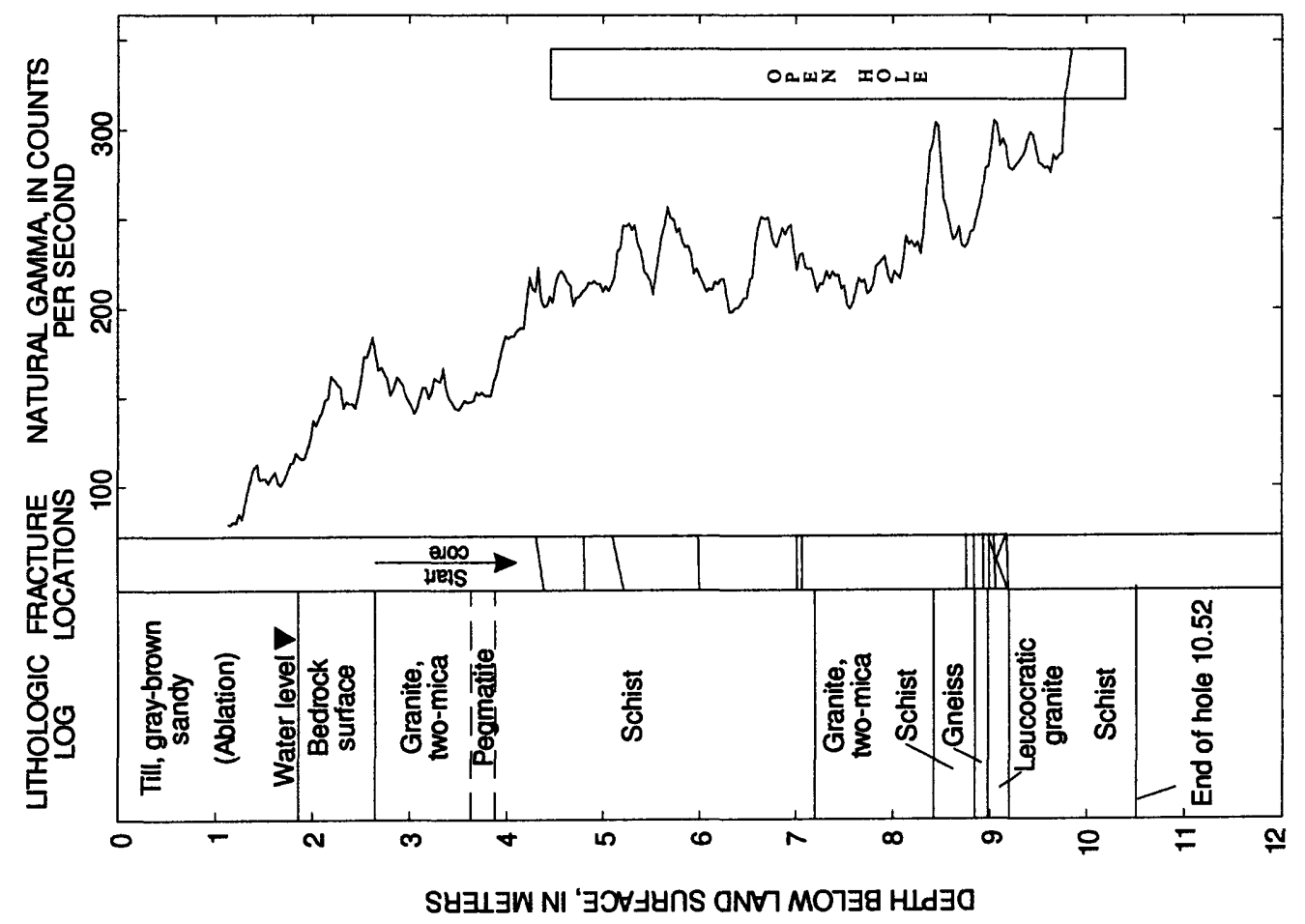

号

Фิ

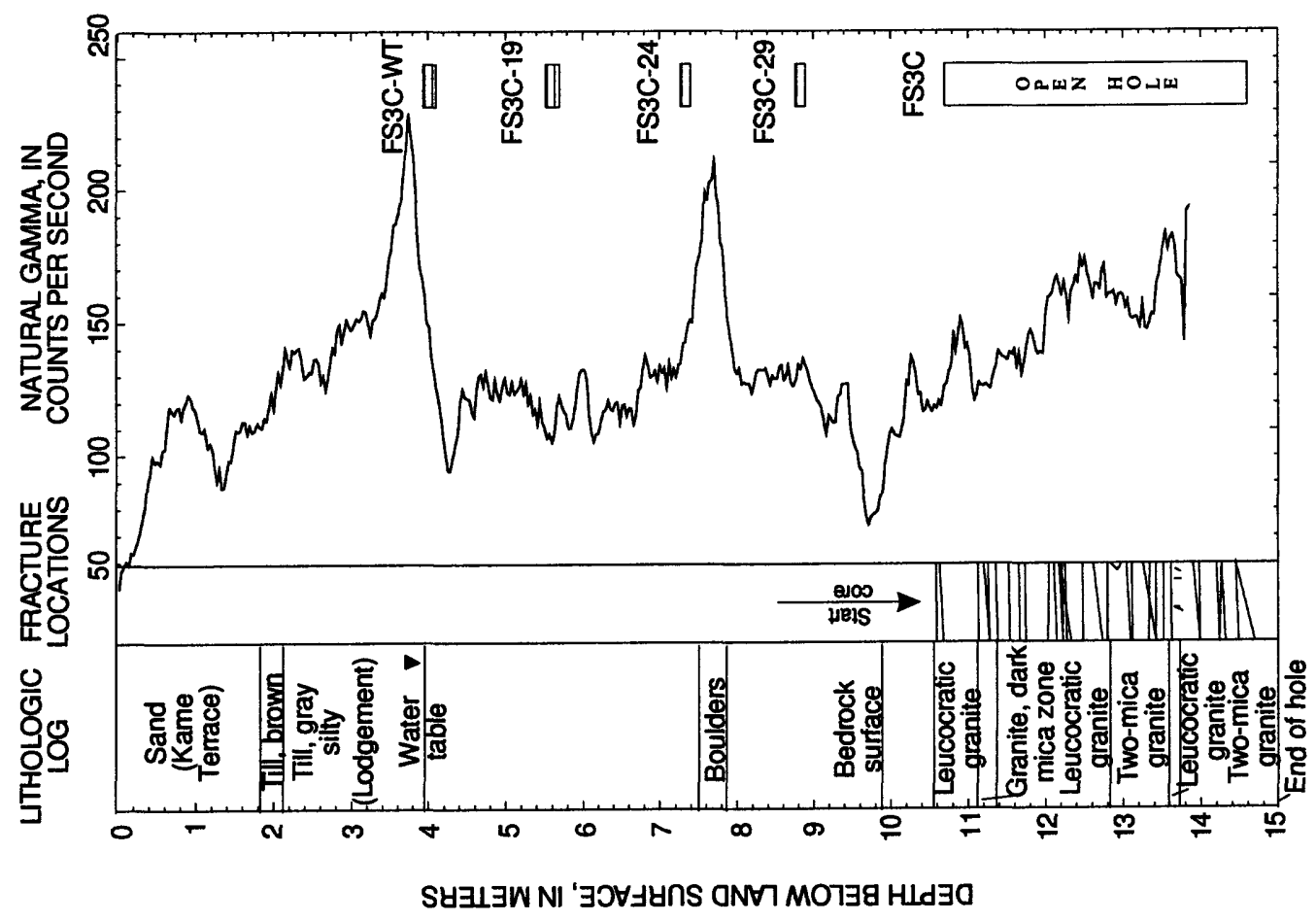

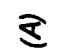

Appendix B 35

- PAGE 37 FOLLOWS - 


\section{APPENDIX C Graph showing water-level responses from slug tests and best-fit lines for:}

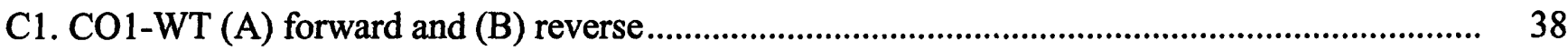

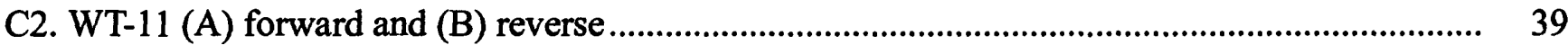

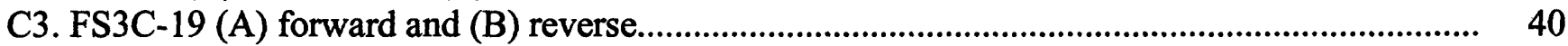

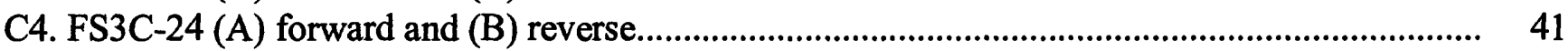

C5. FS3C-29 (A) forward and (B) reverse................................................................................... 42

C6. FS3C forward (A) $\log$ linear and (B) linear log plots ................................................................. 43

C7. CS-20R (A) forward and (B) reverse ....................................................................................... 44

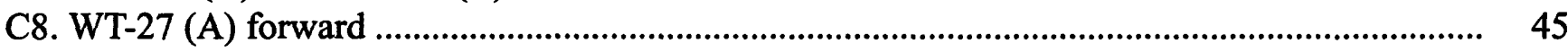

C9. T1-8 (A) forward and (B) reverse ........................................................................................ 46 
(A)

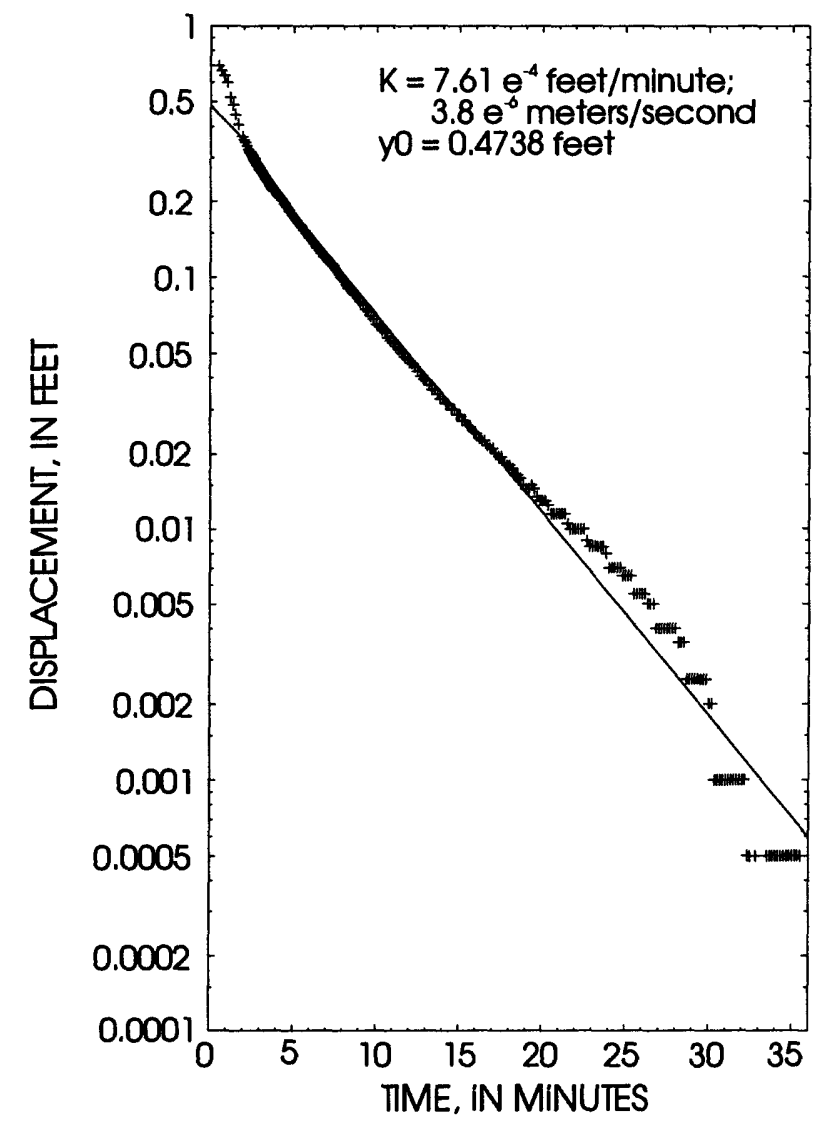

(B)

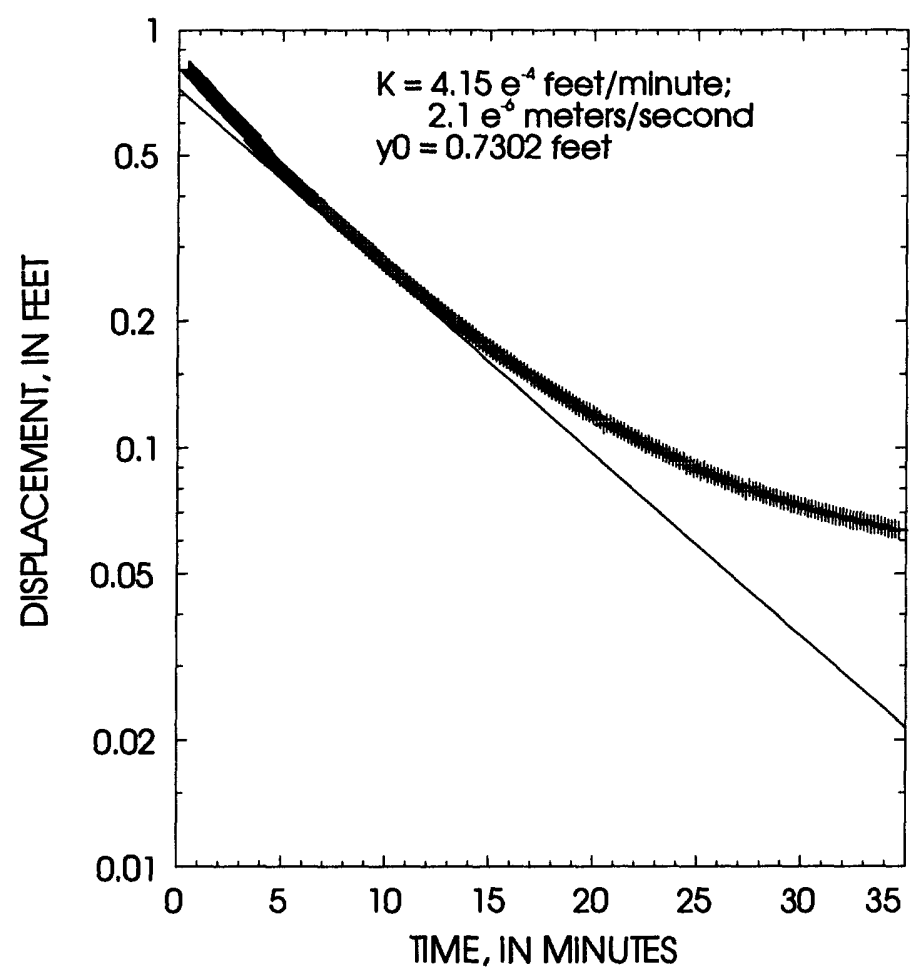

Appendix C1. Water-level responses from slug tests and best-fit lines for CO1-WT: $(A)$ forward and $(B)$ reverse. 
(A)

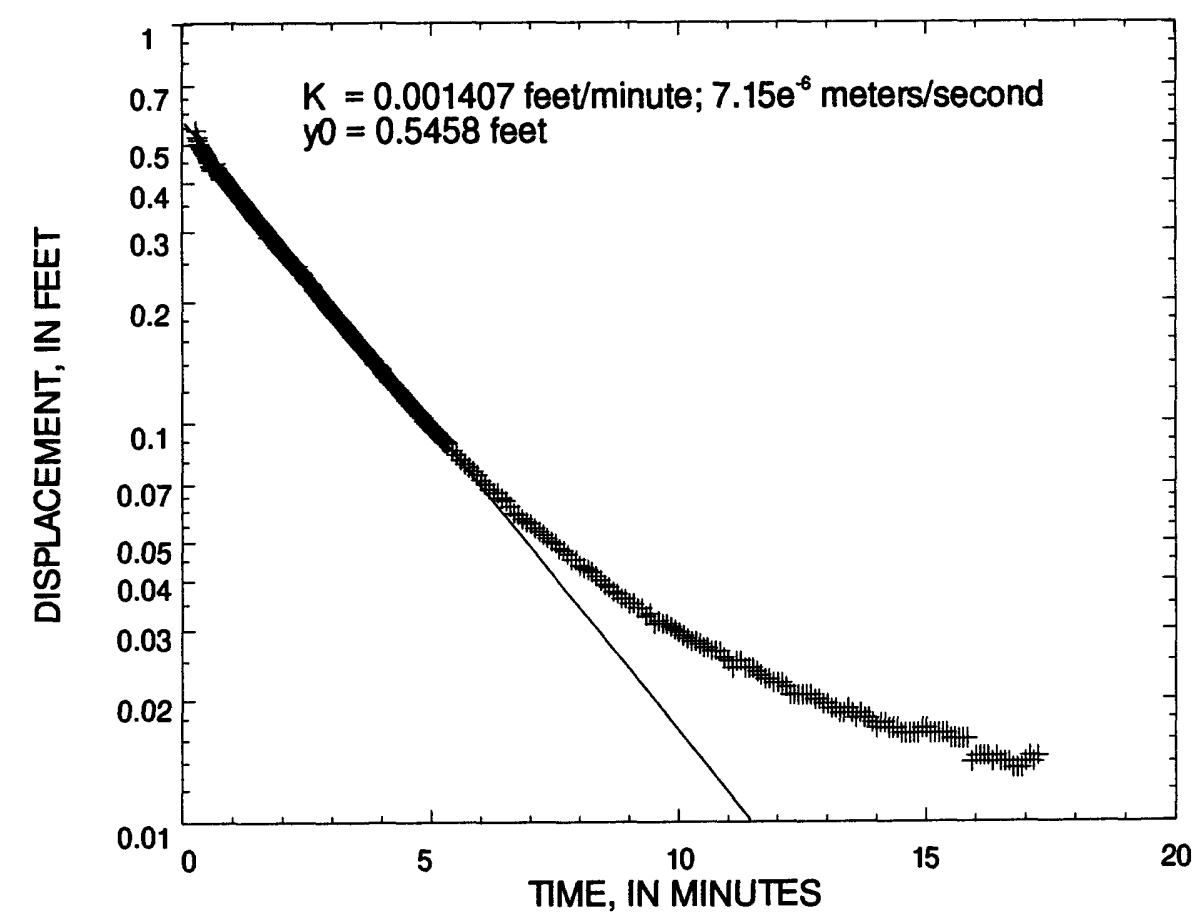

(B)

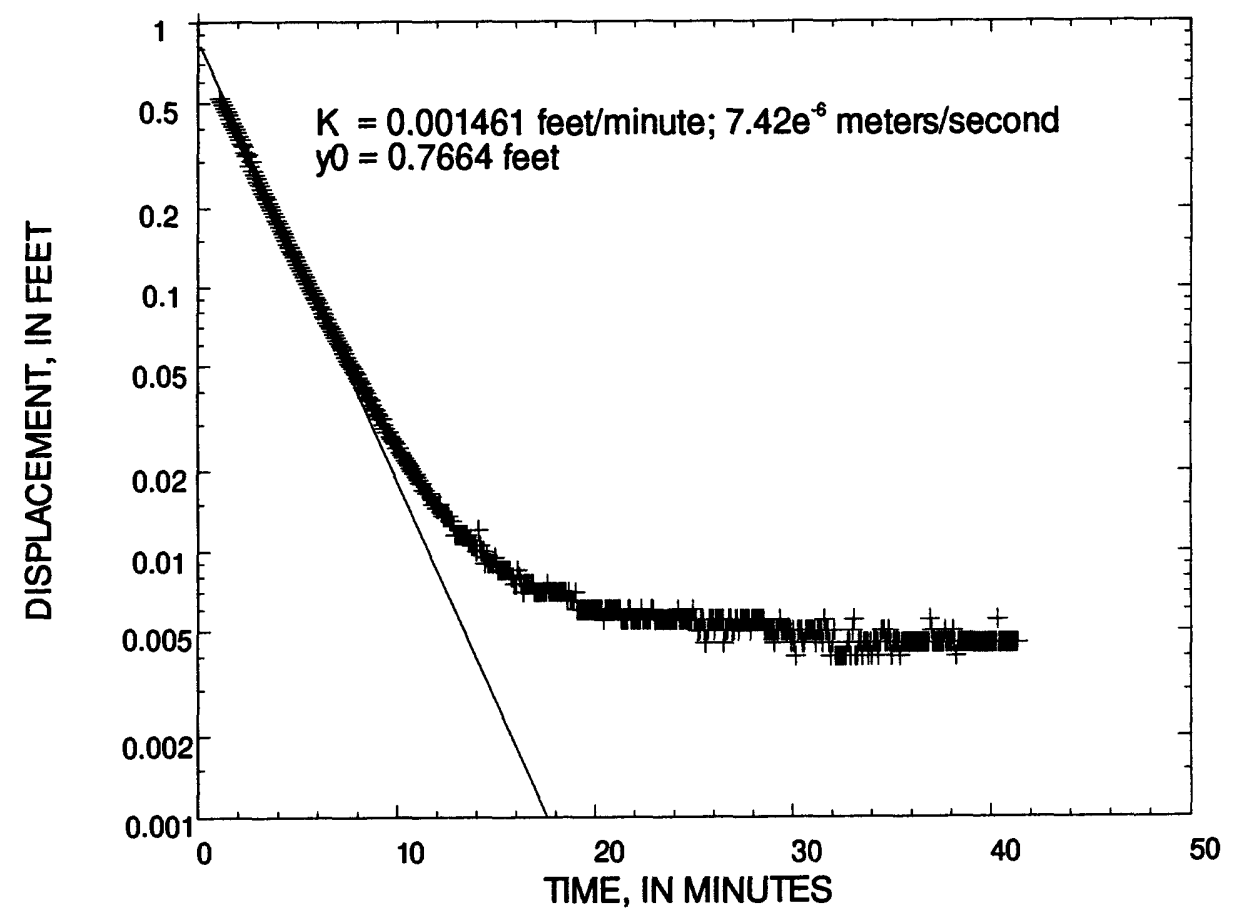

Appendix C2. Water-level responses from slug tests and best-fit lines for WT-11: $(A)$ forward and $(B)$ reverse. 
(A)

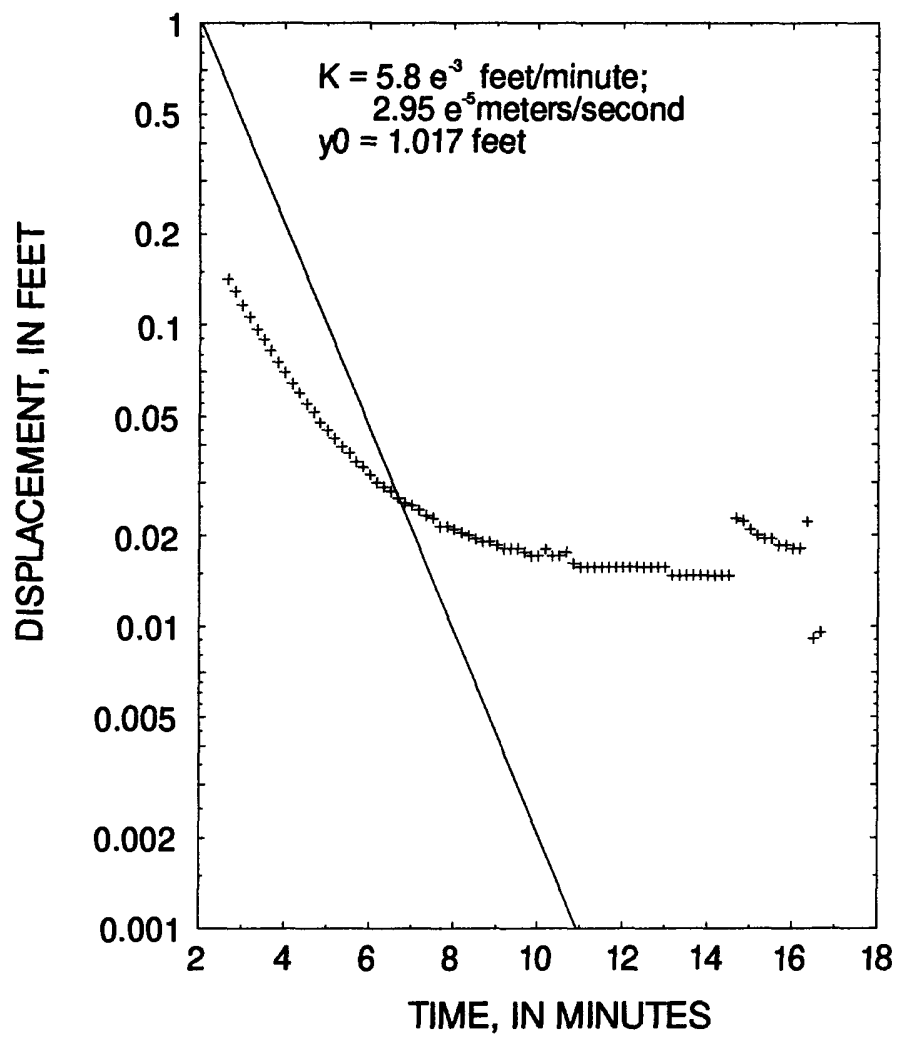

(B)

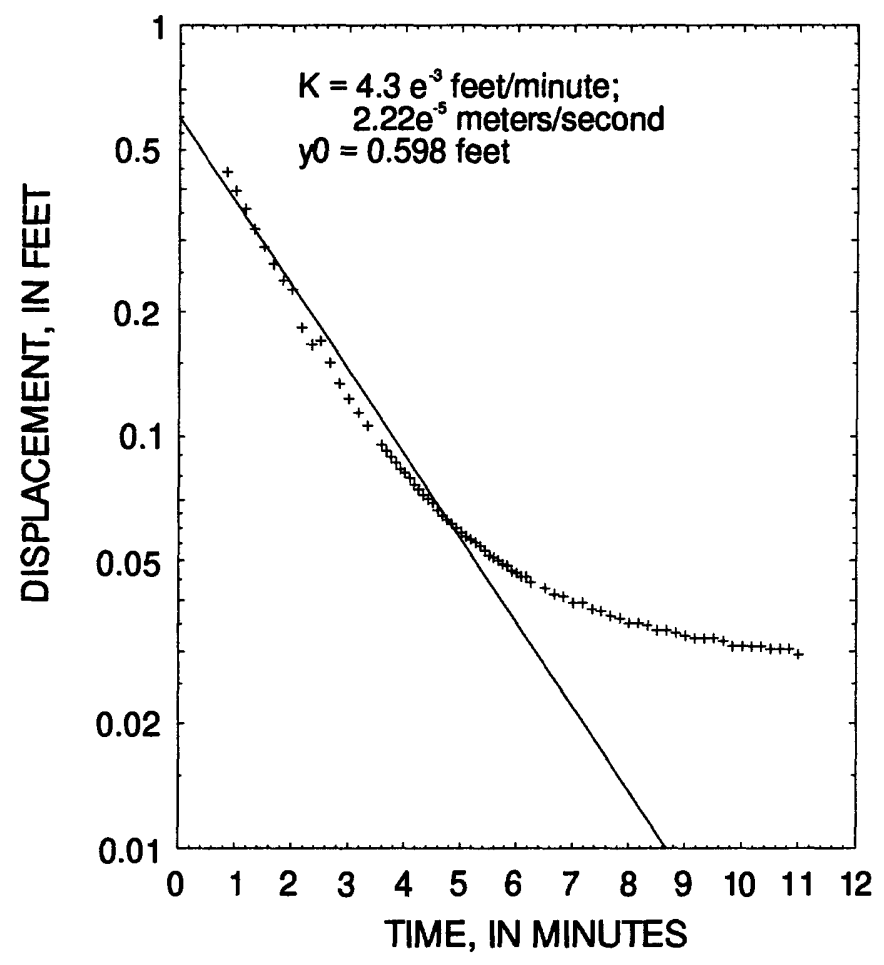

Appendix C3. Water-level responses from slug tests and best fit lines for FS3C-19: (A) forward and (B) reverse. 
(A)

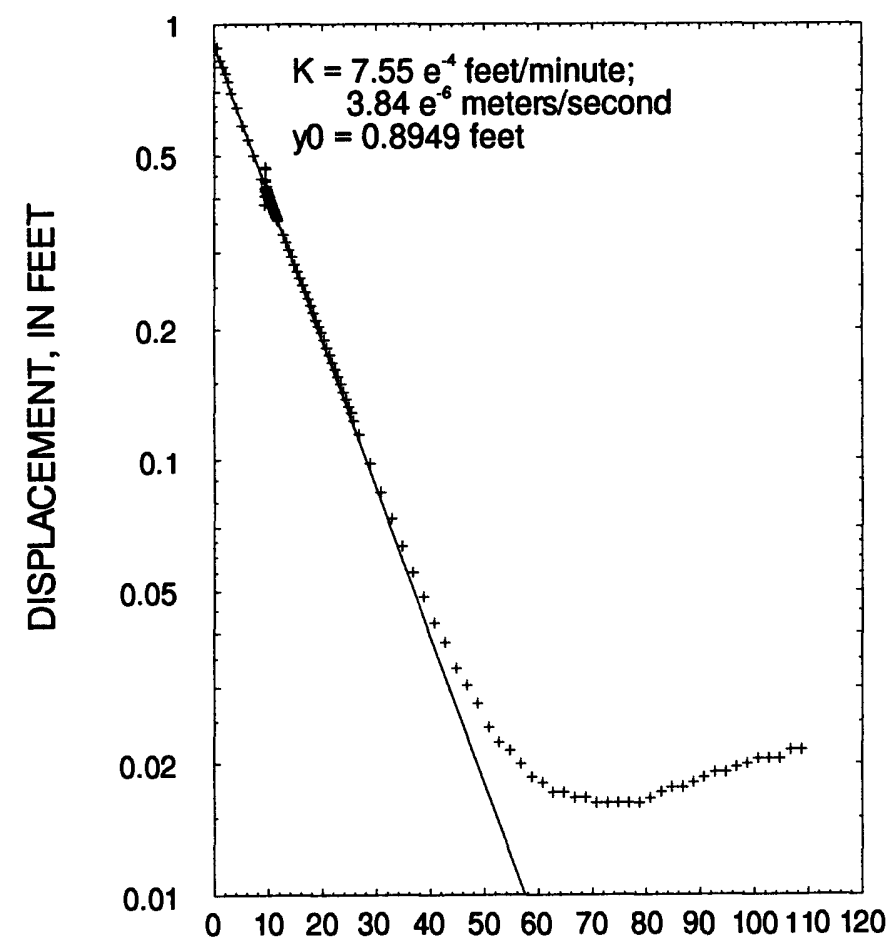

TIME, IN MINUTES

(B)

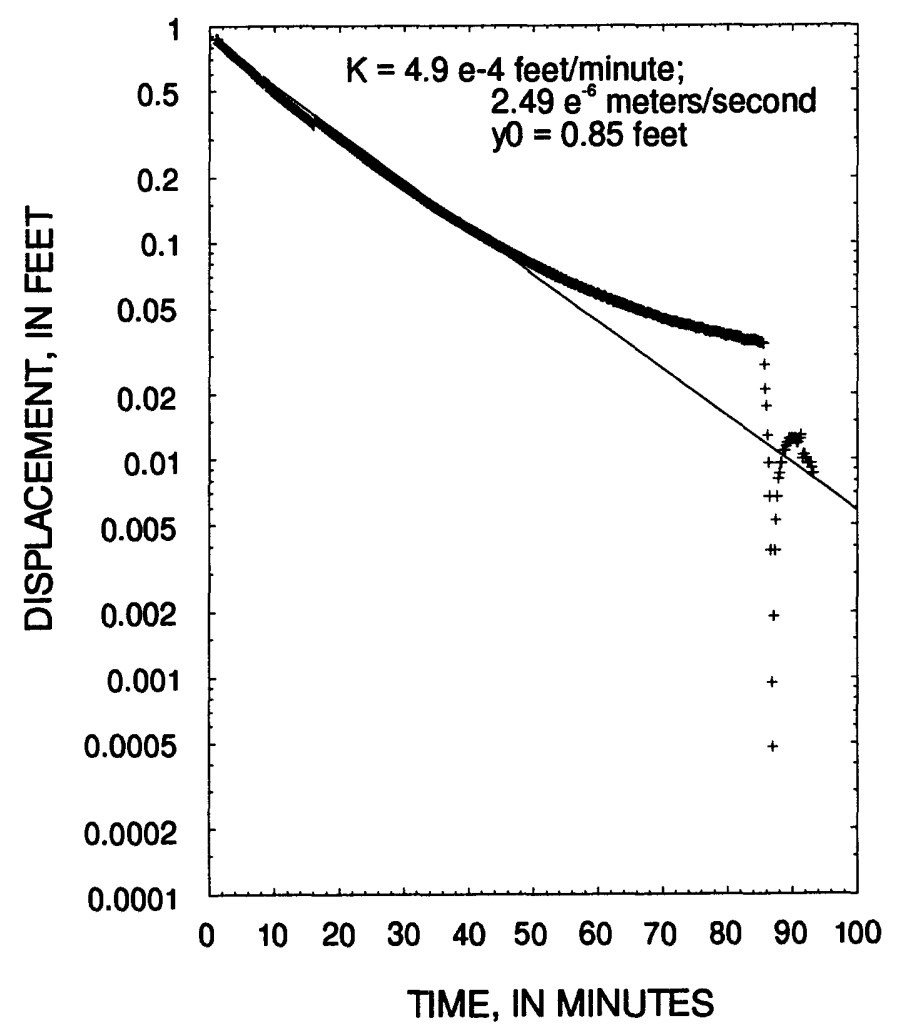

Appendix C4. Water-level responses from slug tests and best-fit lines for FS3C-24: $(A)$ forward and $(B)$ reverse. 
(A)

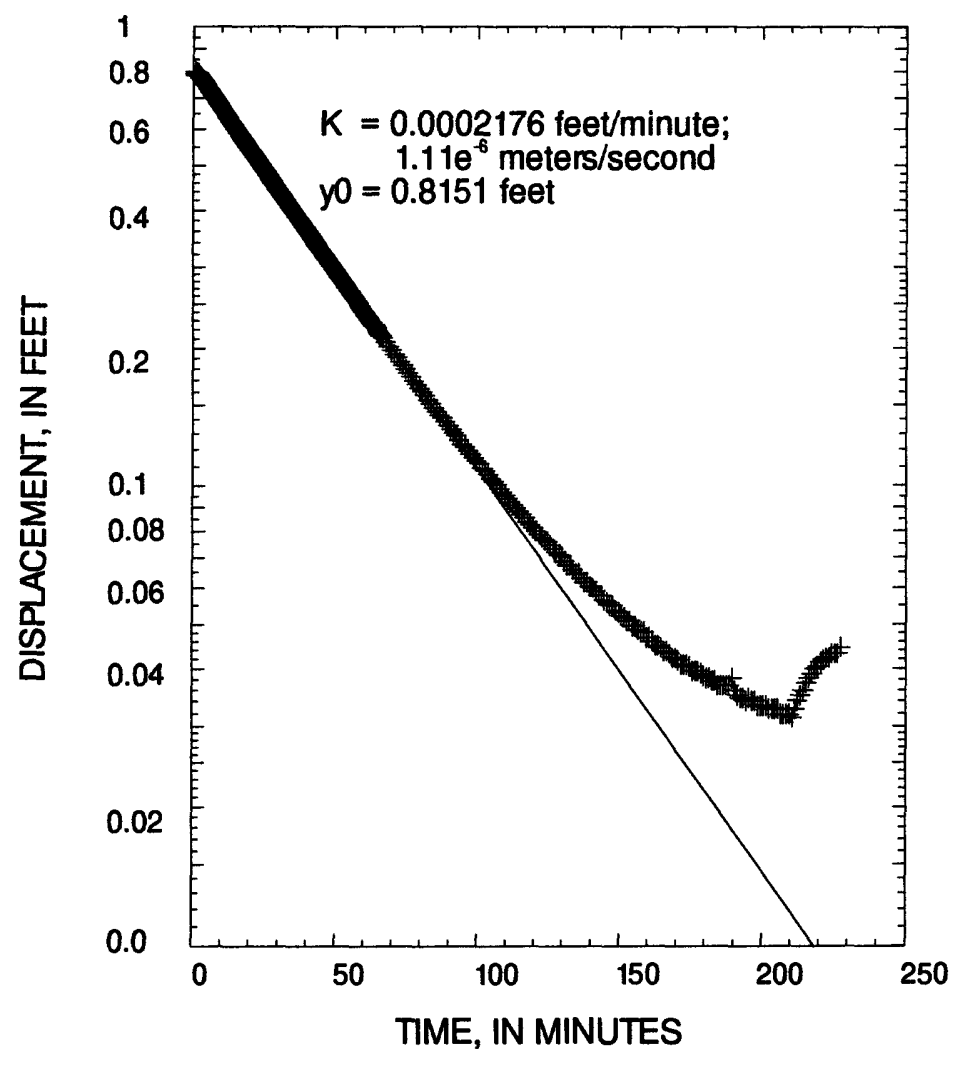

(B)

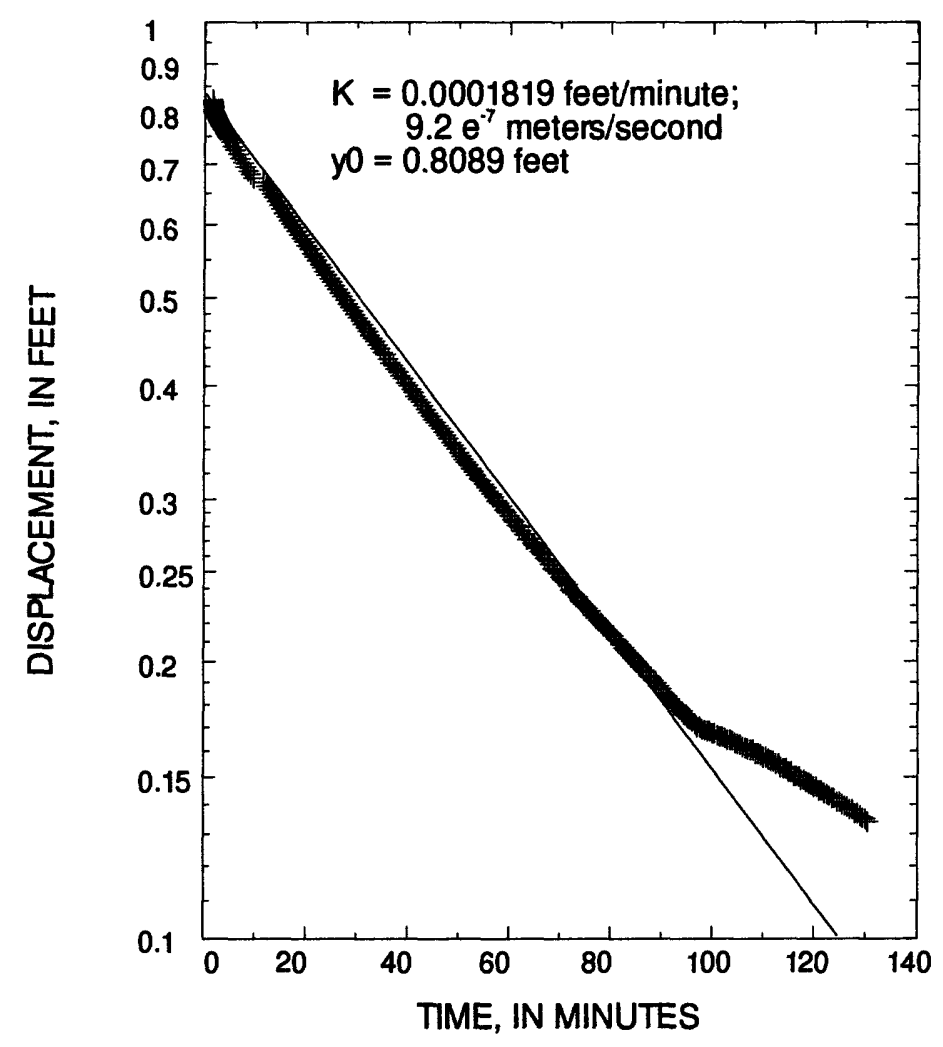

Appendix C5. Water-level responses from slug tests and best-fit lines for FS3C-29: (A) forward and (B) reverse. 
(A)

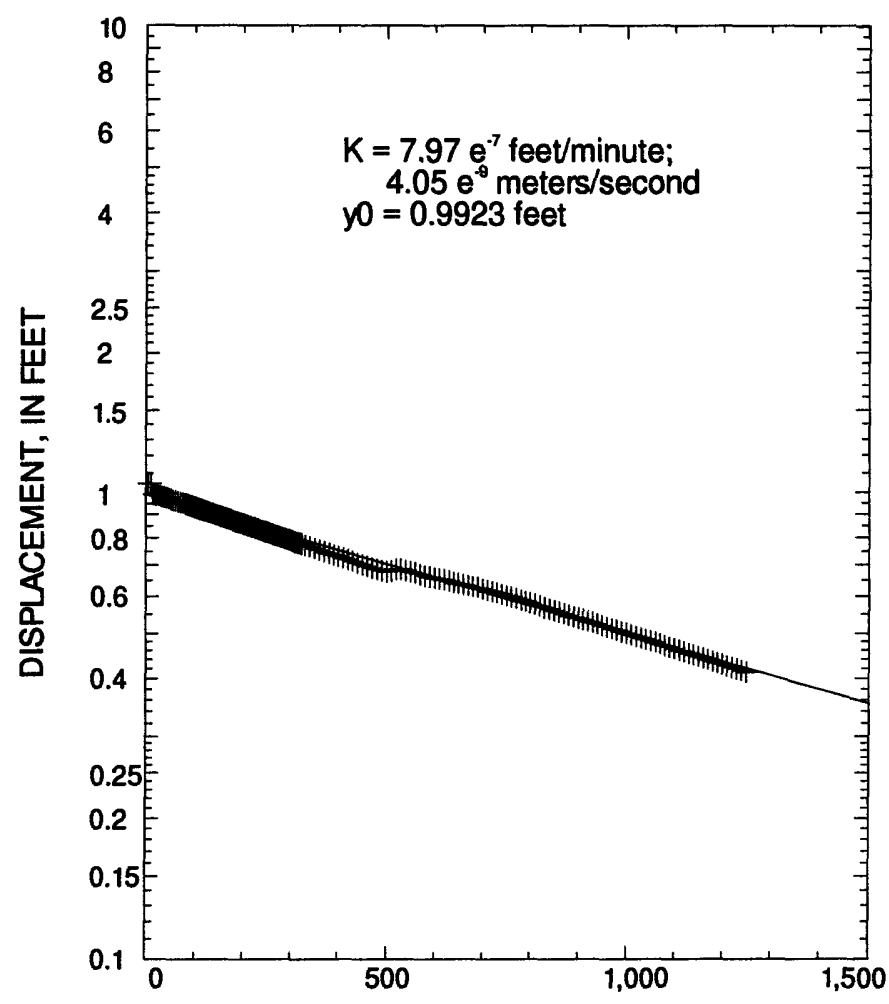

TIME, IN MINUTES

(B)

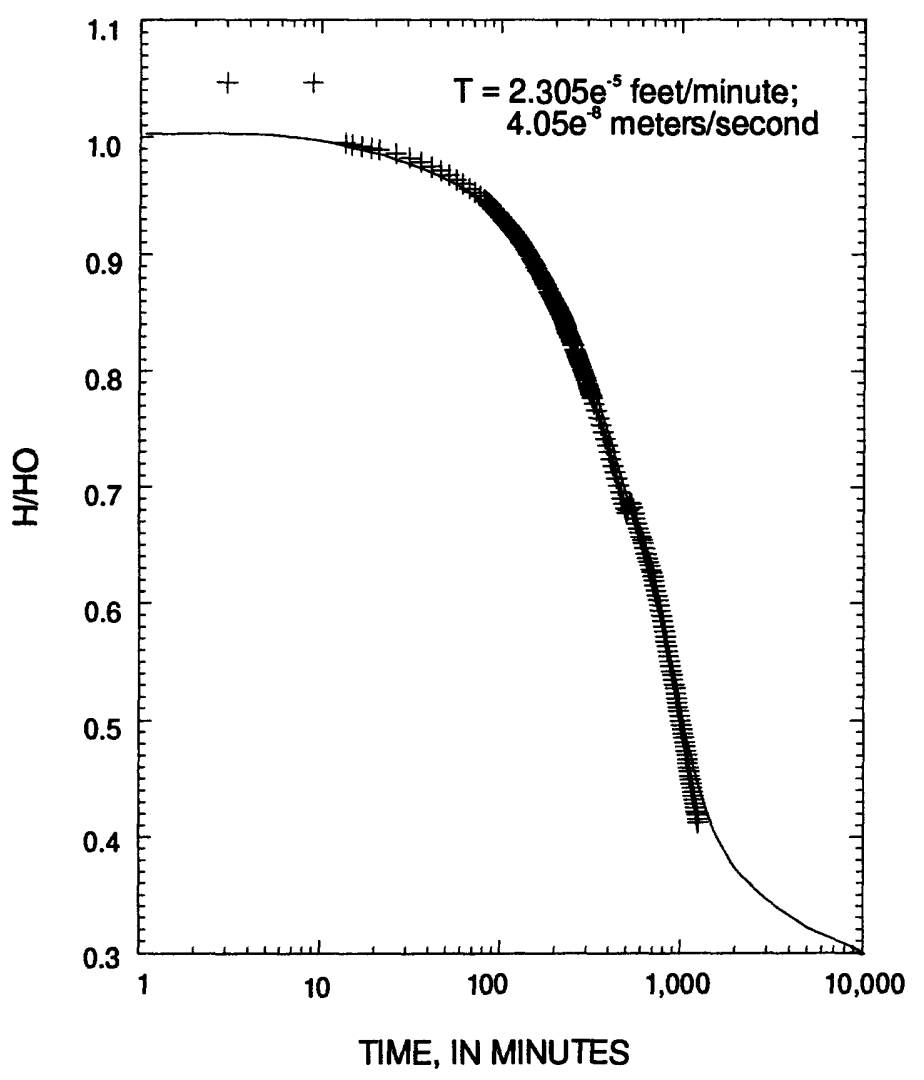

Appendix C6. Water-level responses from slug tests and best-fit lines for FS3C forward (A) log-linear, and (B) linear-log plots. 
(A)

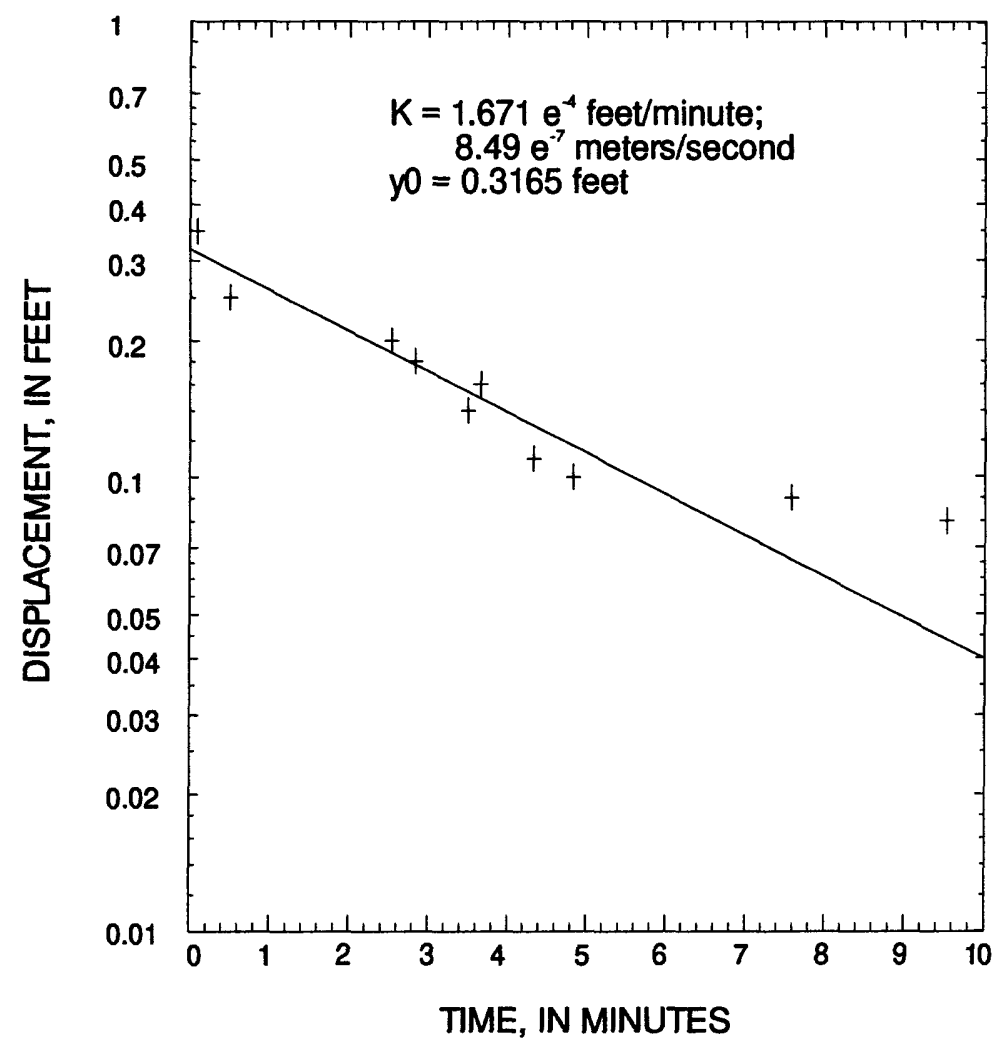

(B)

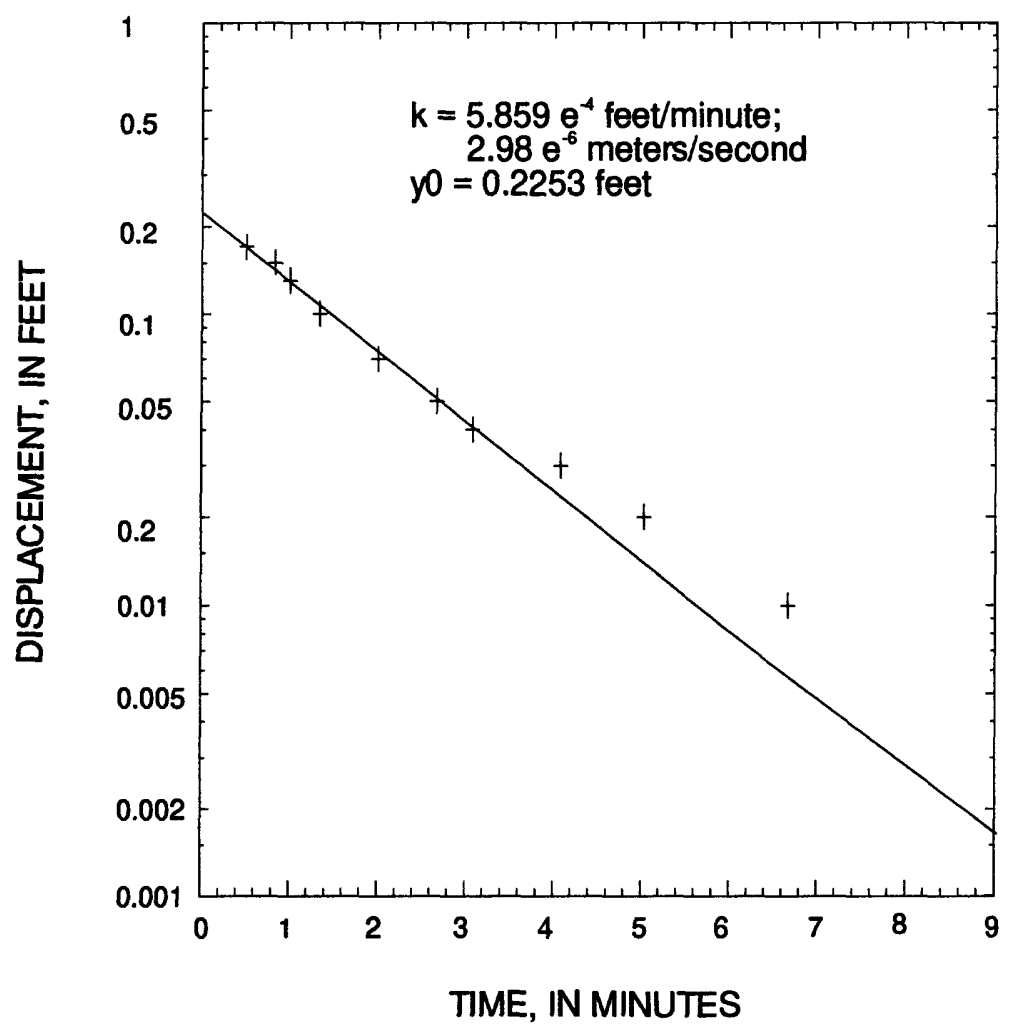

Appendix C7. Water-level responses from slug tests and best-fit lines for CS-20R: (A) forward and (B) reverse. 


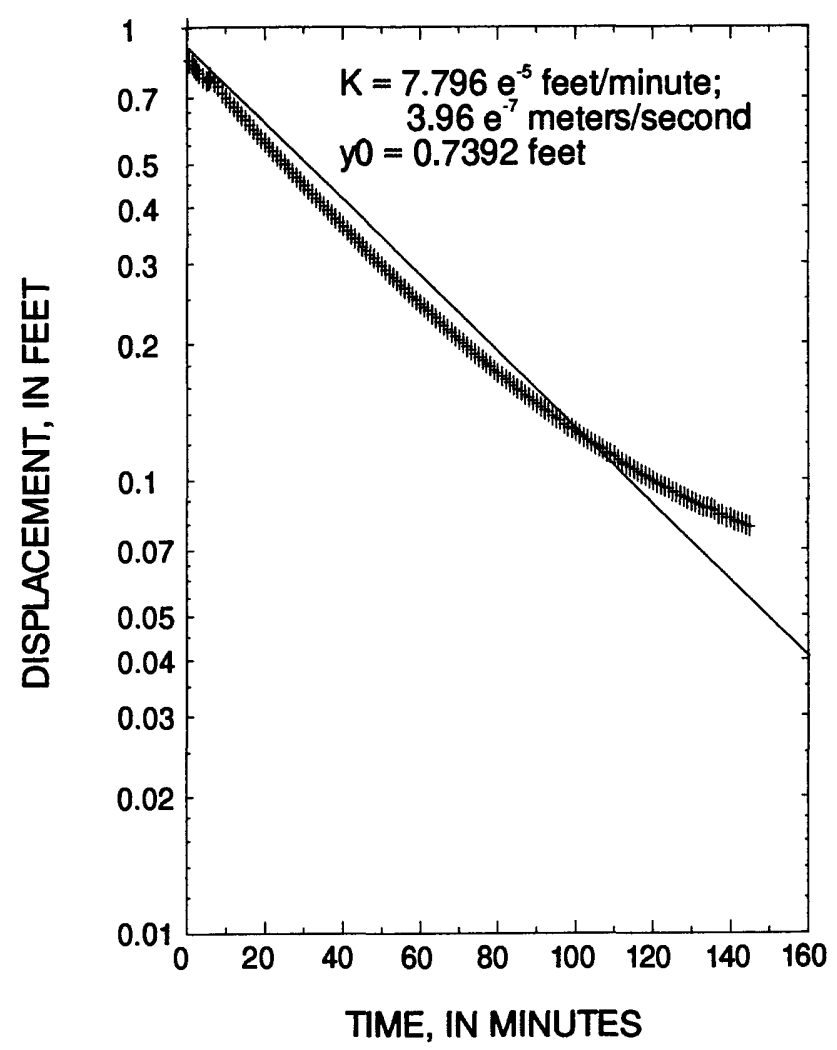

Appendix C8. Water-level response and best-fit line for WT-27 (forward). 
(A)

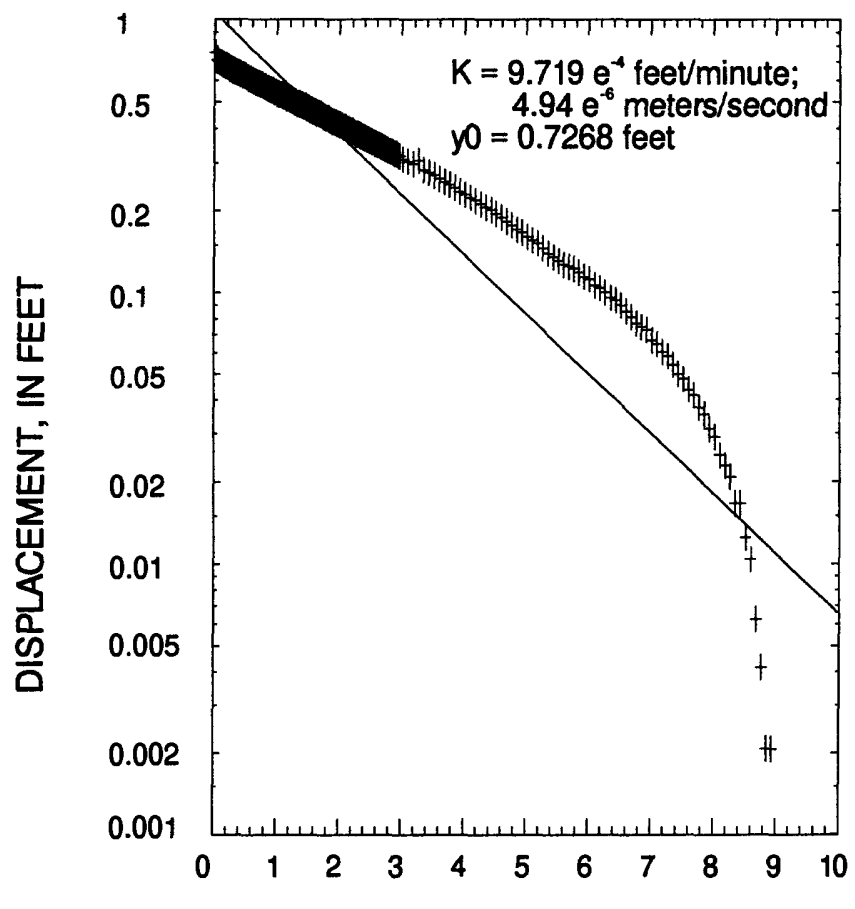

TIME, IN MINUTES

(B)

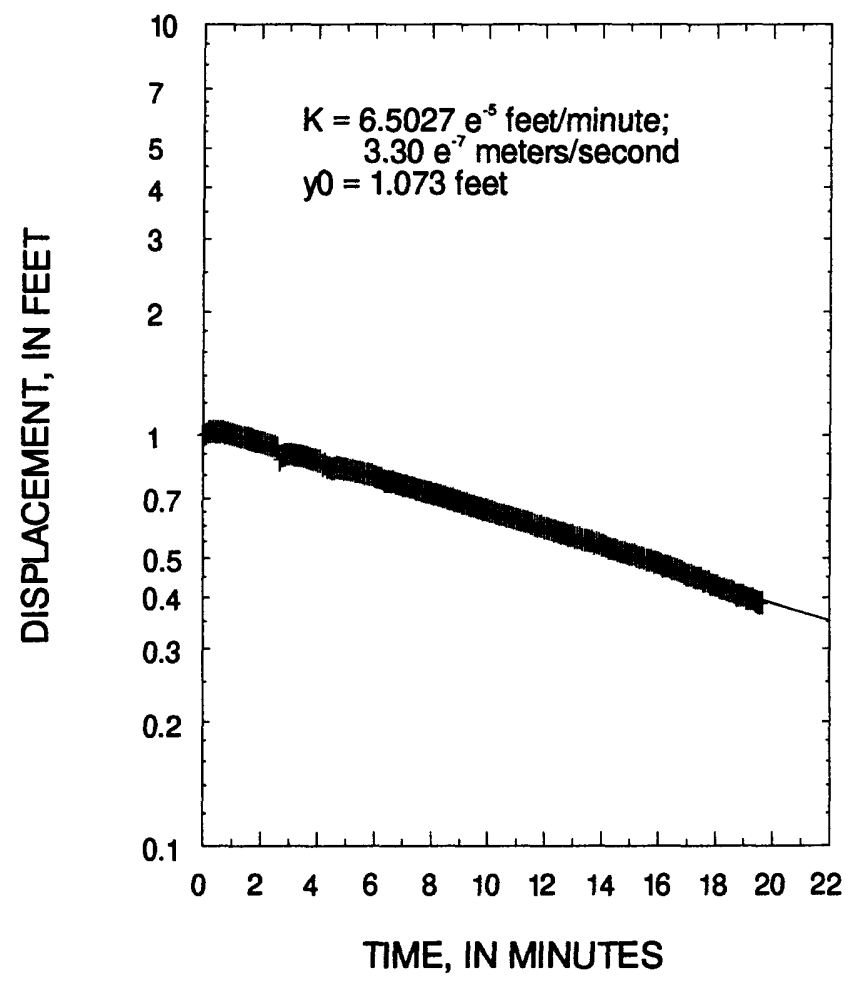

Appendix C9. Water-level responses from slug tests and best-fit lines for T7-8: $(A)$ forward and $(B)$ reverse. 


\section{APPENDIX D}


Table D-1. Information on parameters used for analysis of slug tests, Mirror Lake area, Grafton County, New Hampshire

[All units in meters]

\begin{tabular}{lcccccc}
\hline $\begin{array}{l}\text { Test hoie/weil } \\
\text { (fig.2) }\end{array}$ & $\begin{array}{c}\text { Dispiace- } \\
\text { ment }\end{array}$ & Weil radius & $\begin{array}{c}\text { Effective } \\
\text { radlus }\end{array}$ & $\begin{array}{c}\text { Length of } \\
\text { open } \\
\text { interval }\end{array}$ & $\begin{array}{c}\text { Height of } \\
\text { static } \\
\text { column }\end{array}$ & $\begin{array}{c}\text { Saturated } \\
\text { thickness }\end{array}$ \\
\hline FS3C-19 & 0.64 & 0.025 & 0.025 & 0.152 & 1.57 & 5.03 \\
FS3C-24 & .64 & .025 & .025 & .152 & 2.57 & 5.03 \\
FS3C-29 & .67 & .025 & .025 & .152 & 4.3 & 5.03 \\
FS3C & .64 & .025 & $.038-1.52$ & 3.84 & 9.76 & 5.03 \\
WT-27 & .67 & .025 & .025 & .61 & 3.73 & 5.18 \\
T1-18 & .147 & .025 & .025 & .914 & 1.15 & 1.15 \\
SW-11 & .61 & .025 & $.025-1.52$ & .61 & 1.86 & 6.71 \\
CO1-WT & .61 & .025 & .025 & .61 & 1.65 & 3.69 \\
CS-20R & .122 & .038 & $.038-1.52$ & 5.18 & 8.44 & 8.44 \\
\hline
\end{tabular}




\section{APPENDIX E. WATER LEVEL DRAWDOWNS AND NEUMAN-TYPE CURVES FROM:}

CO1-18 aquifer tests for:

E1. CO1-WT (A) early response and (B) late response................................................................ 50

E2. CO1-18 (A) early response and (B) late response ................................................................... 51

FS3C-29 aquifer tests for:

E3. (A) FS3C-19 (early response) and (B) FS3C-29 (early response)

E4. FS3C (A) late response and a vertical anisotropy ratio of 0.01 of radial, and (B) late response and a vertical anisotropy ratio of 1.0 of radial 
(A)

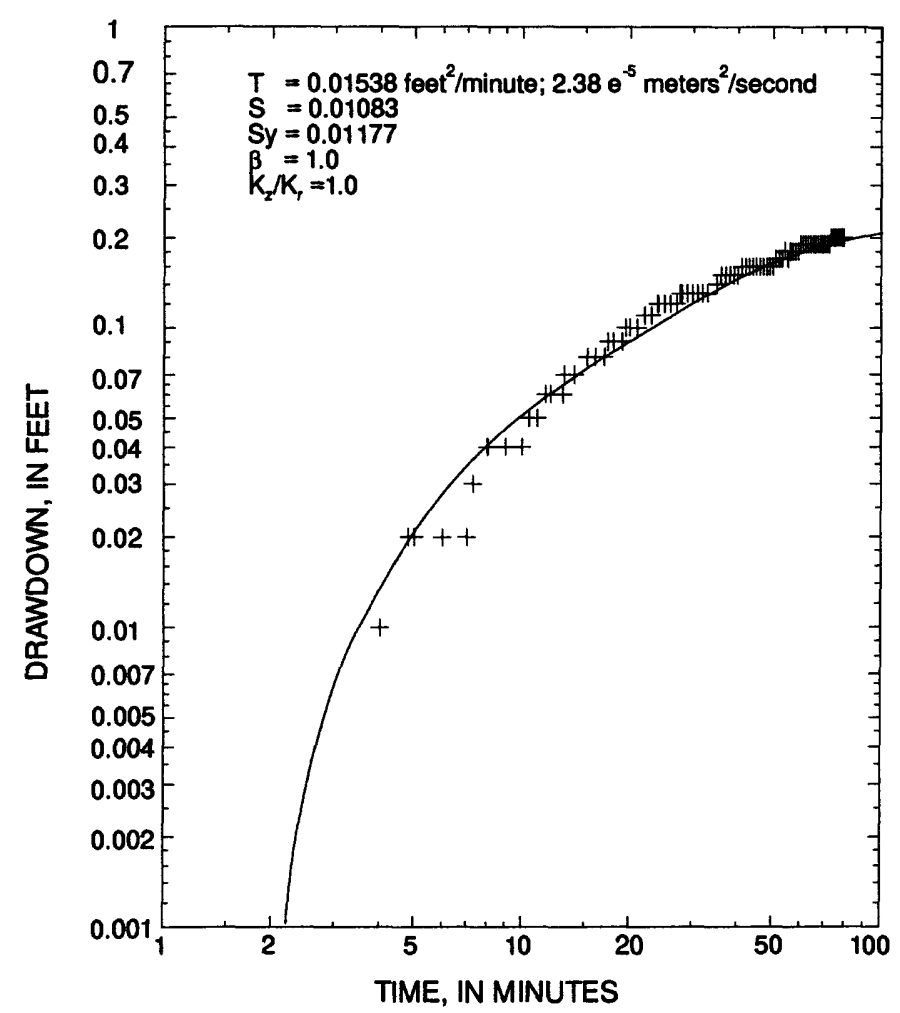

(B)

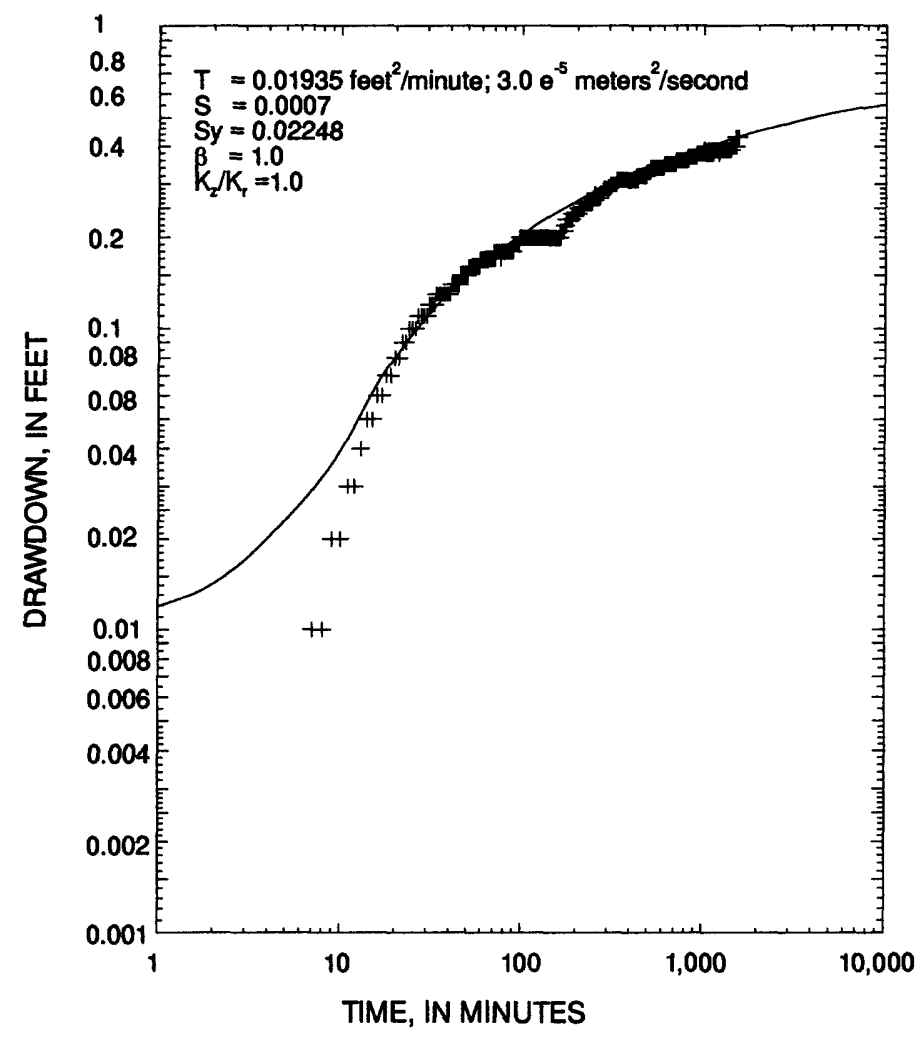

Appendix E1. Water-level drawdowns and Neuman-type curves from CO1-18 aquifer test for CO1-WT $(A)$ early response, and $(B)$ late response. 
(A)

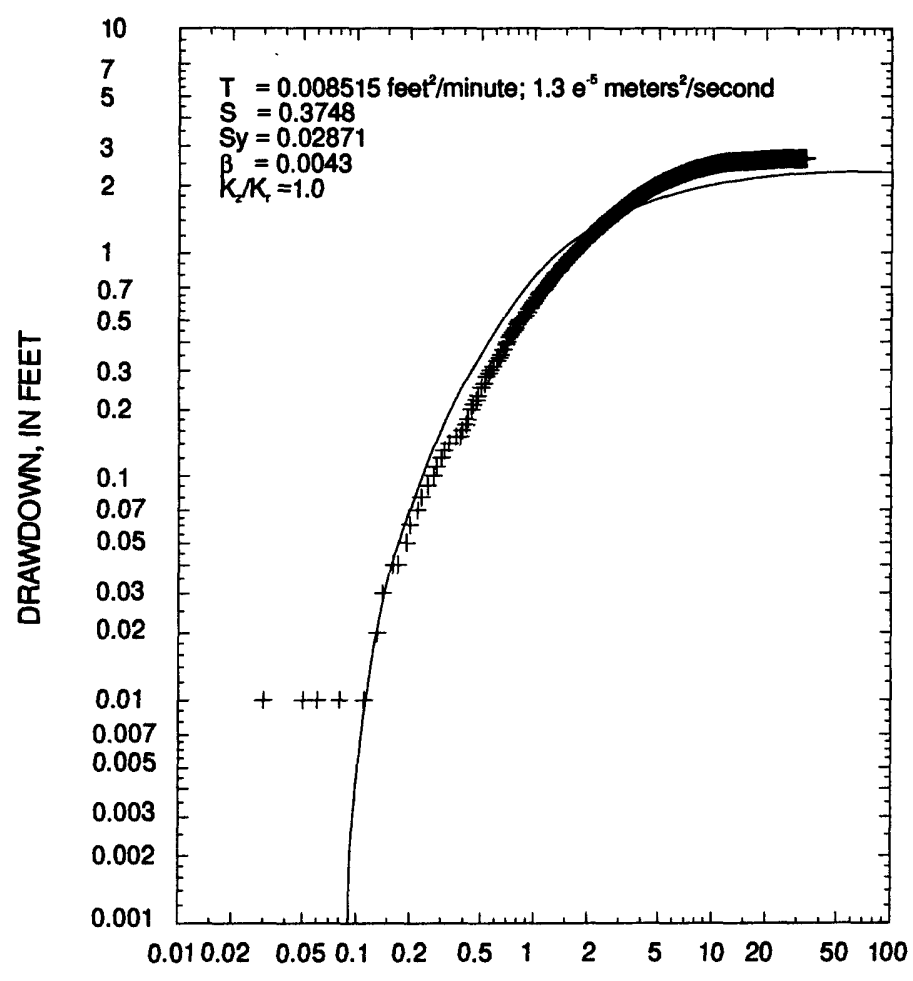

TIME, IN MINUTES

(B)

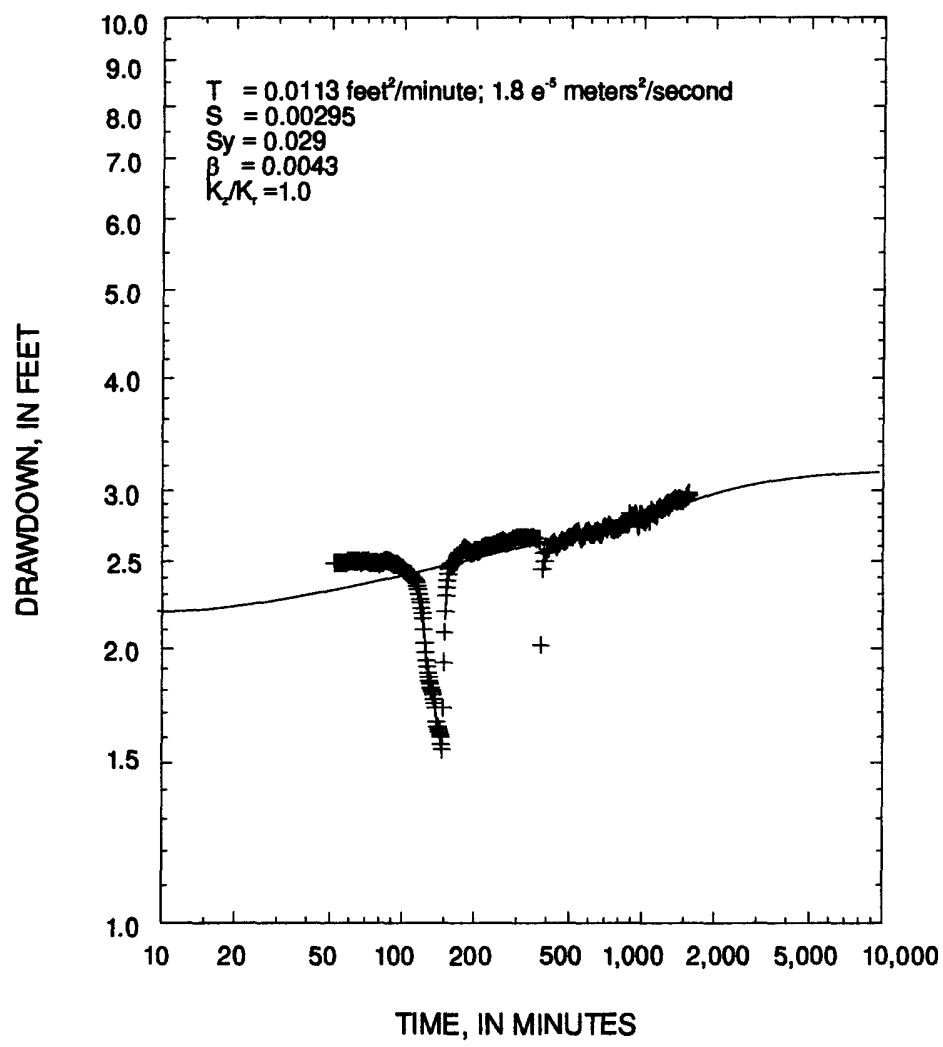

Appendix E2. Water-level drawdowns and Neuman-type curves from CO1-18 aquifer test for $\mathrm{CO1-18}(A)$ early response, and $(B)$ late response. 
(A)

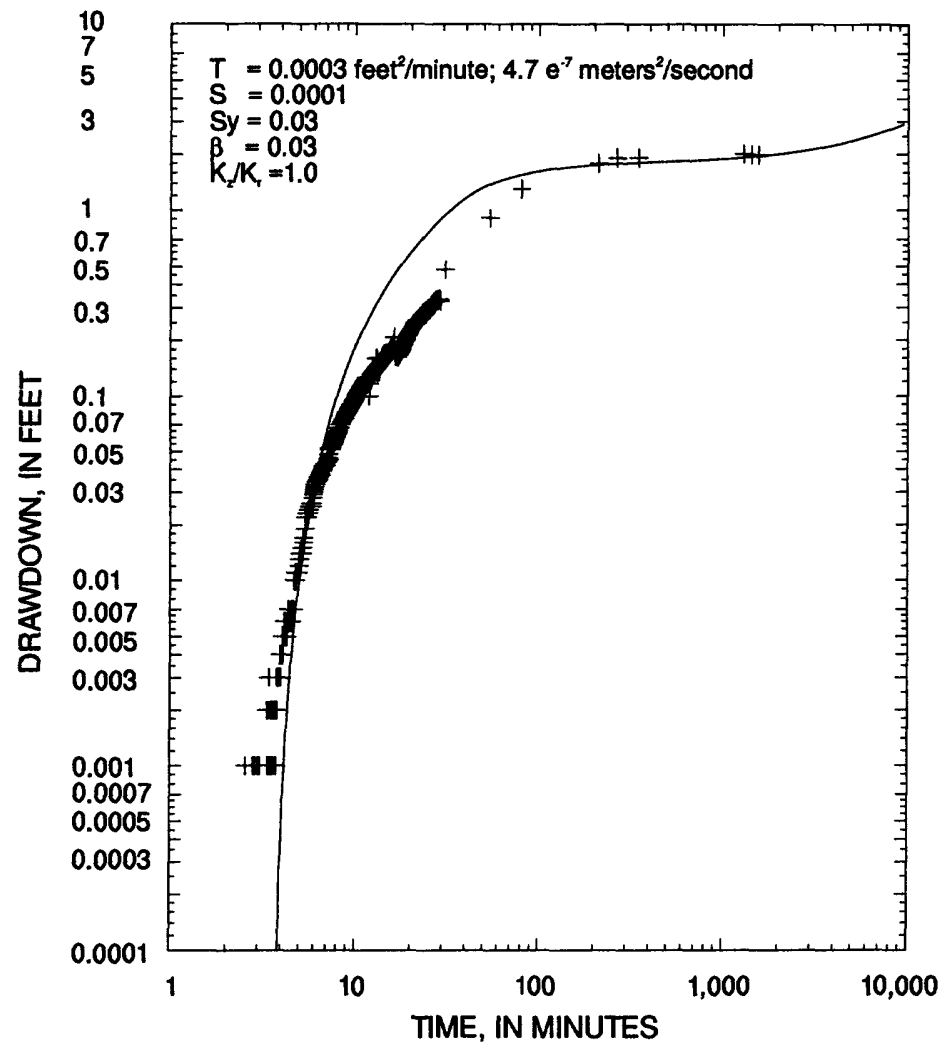

(B)

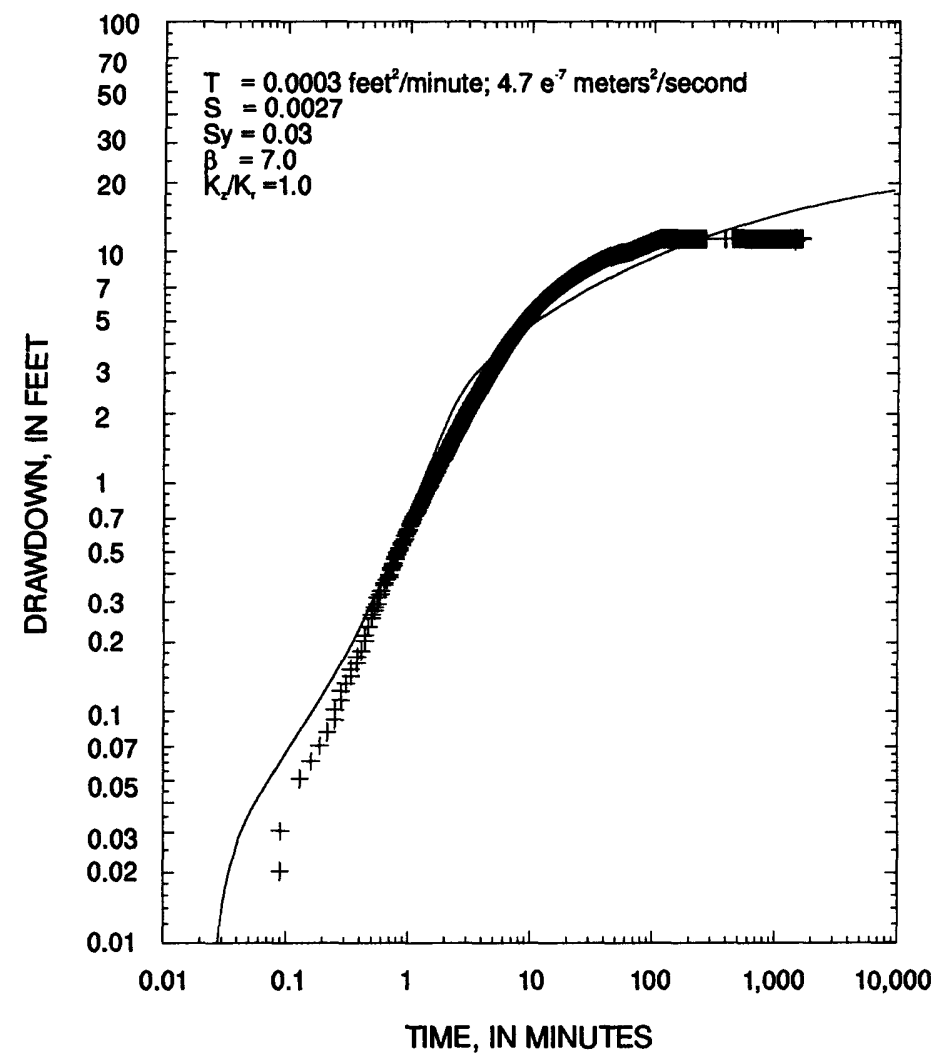

Appendix E3. Water-level drawdowns and Neuman-type curves from FS3C-29 aquifer test for (A) FS3C-19 (early response), and (B) FS3C-29 (early response). 
(A)

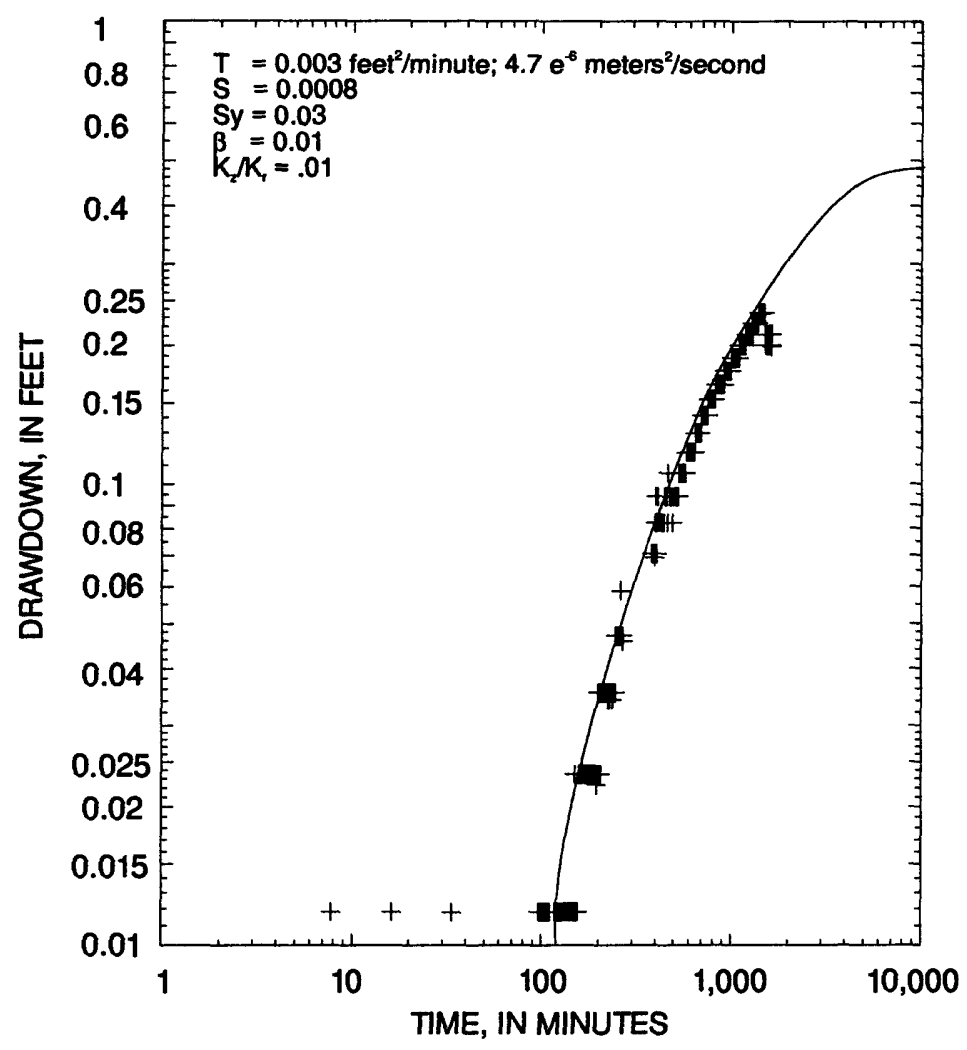

(B)

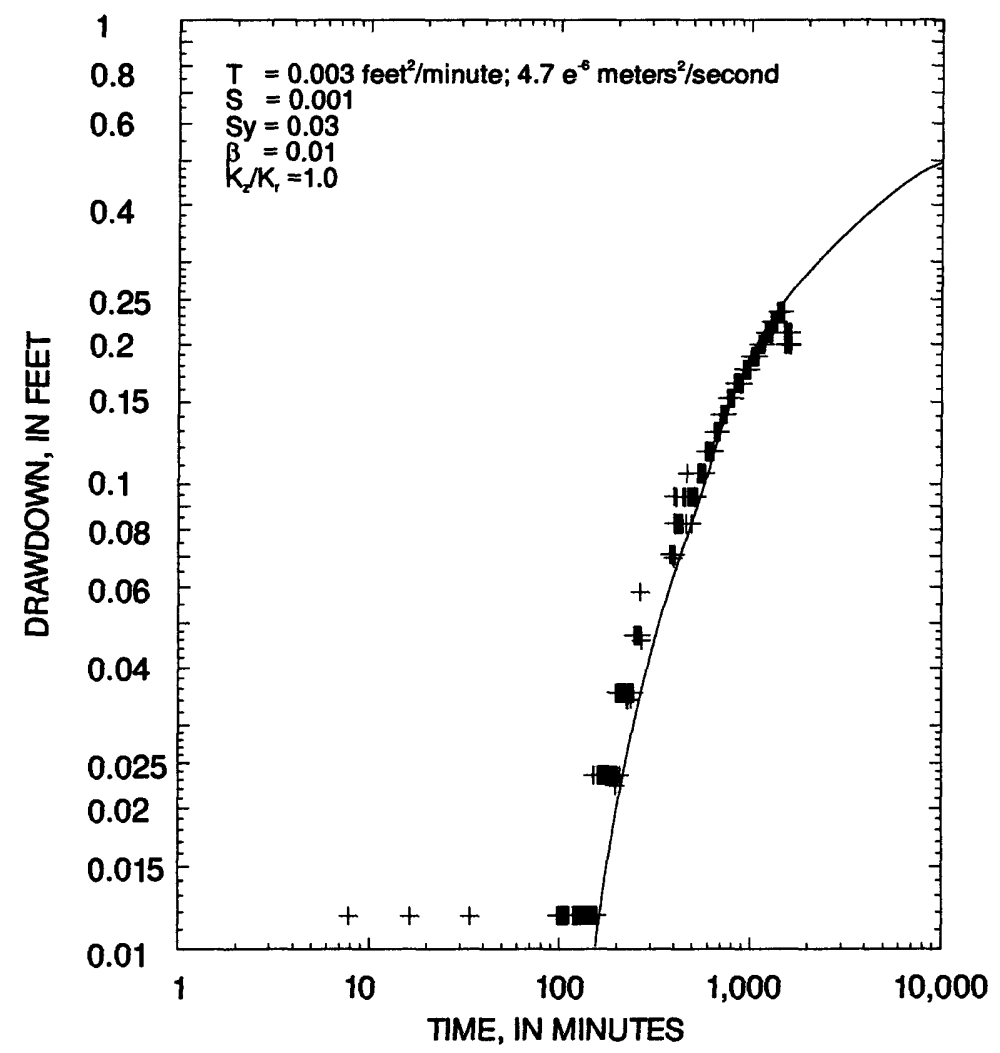

Appendix E4. Water-level drawdowns and Neuman-type curves from FS3C-29 aquifer test for FS3C: (A) late response and a vertical anisotropy ratio of 0.01 of radial, and $(B)$ late response and a vertical anisotropy ratio of 1.0 of radial. 


\section{APPENDIX F}


Table F-1. Information on parameters used for analysis of aquifer test from well clusters FS3C and CO, Mirror Lake area, Grafton County, New Hampshire

\begin{tabular}{|c|c|c|c|c|c|c|c|}
\hline \multirow[b]{2}{*}{$\begin{array}{l}\text { Withdrawal } \\
\text { well }\end{array}$} & \multirow[b]{2}{*}{$\begin{array}{c}\text { Observation } \\
\text { weil }\end{array}$} & \multirow[b]{2}{*}{$\begin{array}{c}\text { Dlstance } \\
\text { from } \\
\text { withdrawai } \\
\text { well } \\
\text { (meters) }\end{array}$} & \multicolumn{2}{|c|}{$\begin{array}{l}\text { Withdrawal rate } \\
\text { (centimeters per } \\
\text { minute) }\end{array}$} & \multirow[b]{2}{*}{$\begin{array}{l}\text { Depth of } \\
\text { Water } \\
\text { (meters } \\
\text { below } \\
\text { land } \\
\text { surface) }\end{array}$} & \multirow[b]{2}{*}{$\begin{array}{c}\text { Open } \\
\text { Interval } \\
\text { (meters } \\
\text { below land } \\
\text { surface) }\end{array}$} & \multirow[b]{2}{*}{$\begin{array}{c}\text { Saturated } \\
\text { thickness } \\
\text { (meters) }\end{array}$} \\
\hline & & & Eariy & Late & & & \\
\hline \multirow[t]{3}{*}{ FS3C-29 } & & 0.052 & 240.0 & 210.0 & 5.0 & $8.76-8.92$ & 9.8 \\
\hline & FS3C-19 & 2.5 & 240.0 & 210.0 & 4.7 & $5.52-5.67$ & 9.8 \\
\hline & FS3C & 23.5 & 240.0 & 210.0 & 5.8 & $10.67-14.51$ & 9.8 \\
\hline \multirow[t]{2}{*}{$\mathrm{CO} 1-18$} & & .052 & 830.0 & 510.0 & 2.7 & $4.64-5.24$ & 3.6 \\
\hline & CO1-WT & 1.22 & 830.0 & 510.0 & 2.8 & $2.74-3.35$ & 3.6 \\
\hline
\end{tabular}

